ISABEL CARDOSO DA CUNHA LOPES ENEI

\title{
ADOÇÃO INTUITU PERSONAE
}

ORIENTADOR: PROFESSOR ASSOCIADO ROBERTO JOÃO ELIAS

FACULDADE DE DIREITO DA UNIVERSIDADE DE SÃO PAULO SÃO PAULO

2009 
ISABEL CARDOSO DA CUNHA LOPES ENEI

\section{ADOÇÃO INTUITU PERSONAE}

Dissertação de mestrado apresentada como requisito parcial para a obtenção do grau de mestre, na área de concentração de Direito Civil, sob a orientação do Professor Associado Roberto João Elias

FACULDADE DE DIREITO DA UNIVERSIDADE DE SÃO PAULO SÃO PAULO 
Para

Vivian Wipfli e

Margarete Pellizari,

mulheres sensíveis juizas exemplares. 


\section{AGRADECIMENTOS:}

A meus irmãos Pedro Cezar Duarte Guimarães e José Virgílio Lopes Enei, e a minha cunhada Claudia Mazitelli Trindade. A José R oberto Leme Alves de 0 liveira, agradeço 0 apoio sem falhas e o carinho sem medida. A Olívia Raposo da Silva Telles, Patricia Maria Laurenti, Caio Silveira Ramos, Carolina Bortoleto Rodrigues, Rosana Ribeiro de Jesus da Silva, Maria Lucinda da Costa, Thelma Thais Cavarzere e Sonia M aria dos Santos Garcia, agradeço a amizade que se manifesta até debaixo da água do dilúvio.

Aos integrantes da rede de proteção à Infância e Juventude de Ribeirão Pires, em especial a Valdir Rigout e Celi Barreto Fukui, da Associação Sant'Anna - Crianças de Ribeirão Pires, aos Conselheiros Tutelares Jadilson de Aquino e Edna Ribeiro Amante, à assistente social judiciária Sílvia Maria Tavares de Oliveira e à psicóloga Veronika Ferber Topic Eleutério, agradeço o exemplo inquebrantável de idealismo e dedicação à causa.

A meu orientador, Professor Dr. Roberto João Elias, agradeço a oportunidade maravilhosa. 
CAPÍTULO I: TERMINOLOGIA; CONCEITOS GERAIS; CONTEXTO HISTÓRICO E CULTURAL; EVOLUÇÃO DO INSTITUTO DA ADOÇÃO NO DIREITO BRASILEIRO

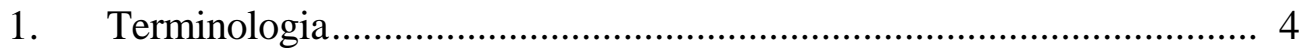

2. O Direito à Convivência Familiar...................................................... . 6

3. A repersonalização do direito de família........................................... 9

4. Evolução histórica da vida em família.................................................. 11

5. Evolução histórica.. ..........................................................................13

6. Abandono e entrega de filhos no Brasil - base cultural.......................16

7. Espécies de Filiação......................................................................... . 19

8. Evolução histórica da Adoção no Direito Brasileiro............................ 21

\section{CAPÍTULO II: PODER FAMILIAR E CONSENTIMENTO PARA COLOCAÇÃO EM FAMÍLIA SUBSTITUTA}

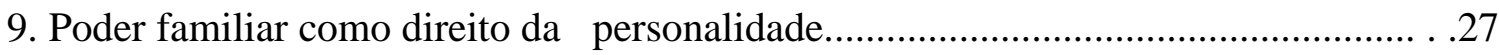

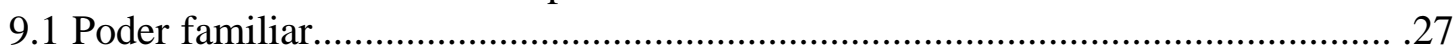

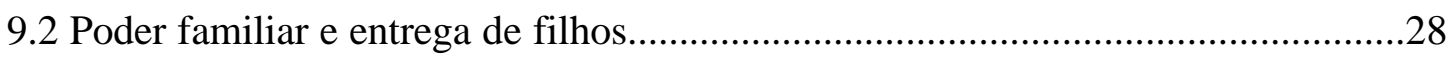

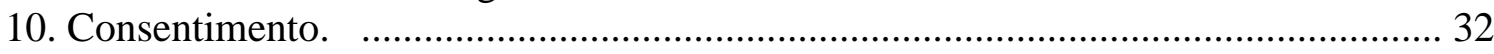

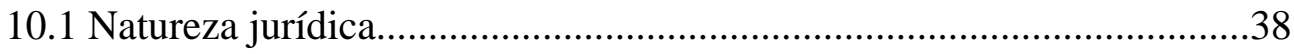

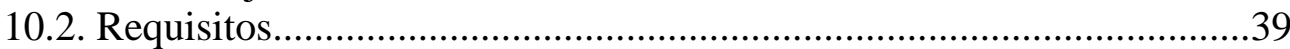

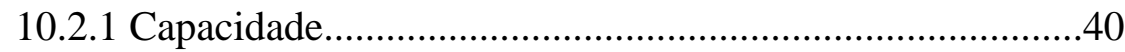

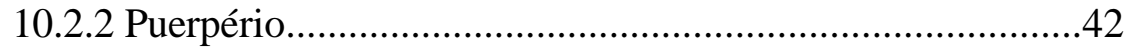

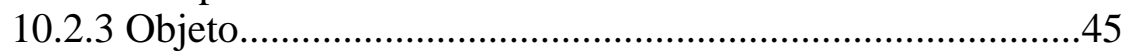

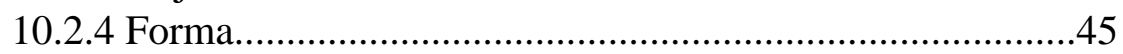

10.2.5 Procedimento..............................................................46

10.2.6 Arrependimento..........................................................46

\section{CAPÍTULO III: A ESCOLHA DOS ADOTANTES}

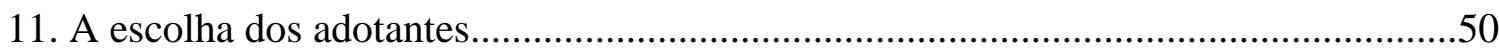

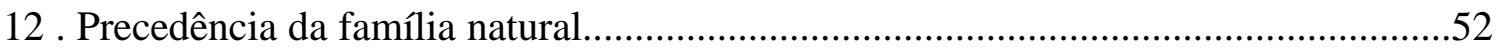

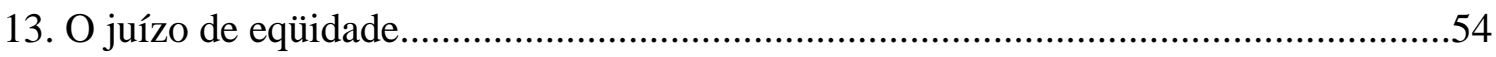

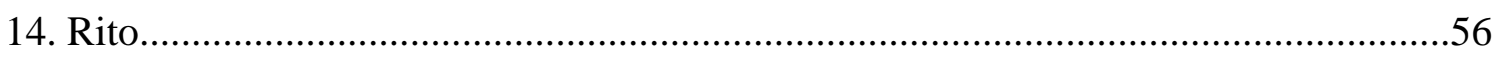

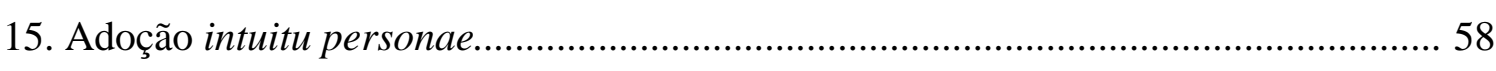

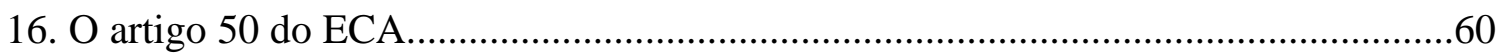

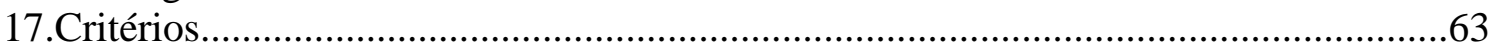




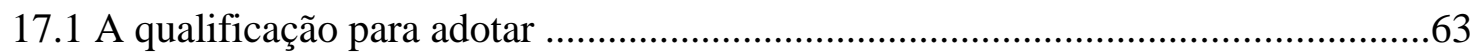

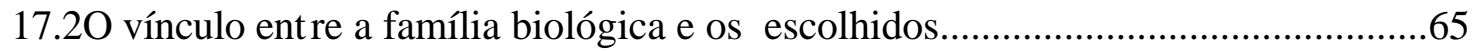

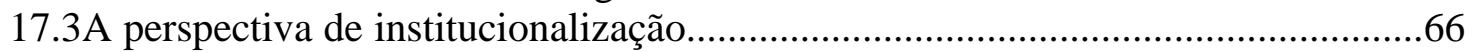

17.4. Adoção intuitu personae e adoção internacional.................................................69

18. Acesso do filho adotivo aos dados sobre sua origem............................................73

\section{CAPÍTULO IV: DIREITO ESTRANGEIRO}

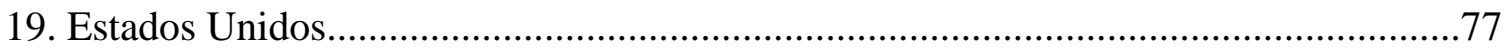

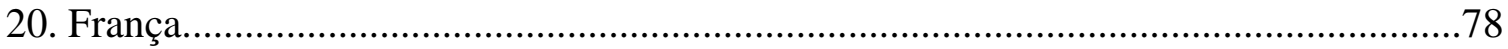

\section{CAPÍTULO V: OUTROS TEMAS}

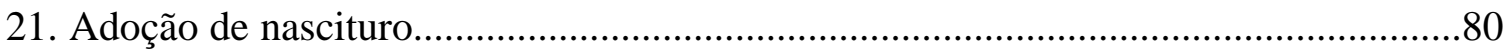

22. Caráter relativo da ordem cronológica de inscrição no cadastro.................................. 81

23. Restrições à escolha do perfil da criança.................................................................. 83

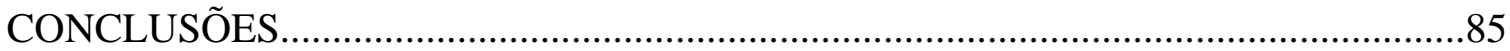

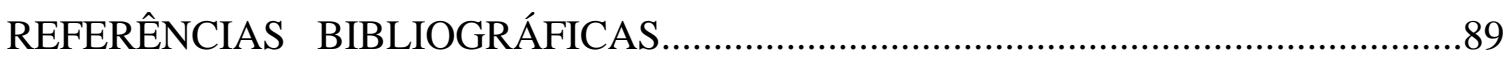




\section{INTRODUÇÃO}

Adotar significa atribuir ao filho alheio os direitos de filho próprio, de acordo com a singela definição de CLÓVIS BEVILÁCQUA; na prática, a adoção é instrumento para formar ou completar famílias, de modo que será sempre essencial para a vida em sociedade e para o Direito.

Aqui cuidamos de examinar a admissibilidade, em nosso ordenamento jurídico, da adoção intuitu personae ("adoção consensual” ou "adoção dirigida”), assim denominada quando a escolha dos adotantes é feita pela mãe biológica ou pelos pais biológicos, e não por órgãos oficiais ou pela autoridade judicial. Sobretudo quando envolve recém-nascidos, essa modalidade é objeto de controvérsia e de práticas judiciárias muito díspares.

Há grave desencontro de informações em nosso meio jurídico. É um estado de coisas que reflete a realidade social prosaica: pequenos grupos entram nos fóruns, em geral desacompanhados de advogado, com o objetivo de regularizar sua situação. São casais acompanhados de uma mulher que acabou de receber alta hospitalar e do recémnascido a que ela deu à luz. Dizem: "queremos passar o bebê no nosso nome....", convencidos de que a questão se resume ao aspecto do registro civil.

Às vezes se descobre que a mãe biológica entregou o filho recém-nascido a desconhecidos tão-somente porque soubera que eles tinham casa própria. E quer que prevaleça o critério, mesmo se alertada de que não é o melhor. Situação delicada, em que se questiona não a capacidade na acepção civil, mas as condições de discernir o bem do mal, o conveniente do inconveniente.

São inúmeras as situações em que ocorre a adoção "intuitu personae”. Em se tratando de recém-nascido, todas envolvem pessoas extremamente vulnerável: o bebê; a mãe biológica, em geral premida pela pobreza e possivelmente afligida pelo puerpério; os adotantes, prestes a criar o vínculo maior de afeto com uma criança que ainda não sabem se será mesmo sua.

Conquanto não exista proibição em nosso ordenamento jurídico (a única proibição existente é a de entregar filho sob promessa de paga ou recompensa, conduta prevista como crime no art. 238 do Estatuto da Criança e do Adolescente), muitos profissionais do direito não reconhecem a adoção intuitu personae. Justificam seu entendimento no artigo 50 do Estatuto da Criança e do Adolescente, que instituiu o 
cadastro dos interessados em adotar; raciocinam que, se a lei instituiu o cadastro, só pessoas cadastradas poderiam adotar.

A conseqüência prática desse entendimento, no contexto das situações fáticas evocadas, seria a imediata retirada da criança da posse dos pretendentes à adotá-la e sua colocação em entidade de abrigo, à espera dos primeiros cadastrados. Mas não será difícil imaginar as possíveis dificuldades: a mãe biológica retira o consentimento, diz que ela própria ir criar o filho (suscitando a dúvida: cuida-se de arrependimento real ou subterfúgio para entregá-lo a terceiros que não façam questão de formalizar o ato?); os pretendentes se insurgem; os cadastrados não se interessam pela criança etc.

Há quem entenda, ao contrário, que a situação merece um tratamento mais simples: um termo de guarda e responsabilidade é concedido e os pretendentes saem orientados a voltar dali a algum tempo para pleitear a adoção.

Novamente é possível prever dificuldades: nesse intervalo, a mãe biológica talvez não seja mais encontrada, ou pode ser encontrada e se insurgir, porque se arrependeu... fatores de incerteza e insegurança, em suma.

Nenhuma das duas orientações está infensa a desdobramentos infelizes. Fazse necessário, todavia, dotar de maior segurança os procedimentos judiciais, para reduzir o grau de imprevisibilidade nessas situações tão freqüentes e tão delicadas.

O aperfeiçoamento dos mecanismos de criação de famílias adotivas é imperativo, decorre do caráter fundamental ao direito à convivência familiar, apresentado no capítulo I.

Foi preciso refletir sobre a natureza jurídica do consentimento para colocação de filho em família substituta, se renúncia ao poder familiar, tradicionalmente qualificado como irrenunciável, ou se instituto peculiar. É o objeto do capítulo II. A exata compreensão e a classificação do consentimento enquanto ato jurídico são vitais para a análise do aspecto da validadeL e para instituir um tratamento jurídico adequado ao fenômeno do arrependimento (se faculdade, se direito, se condicionado).

No capítulo III, afirma-se que a regra que preside a escolha dos adotantes é a do efetivo benefício ao adotando, fundada na supremacia do melhor interesse da criança (expressão que equivale à fórmula anglo-saxônica “child's best interest”). Conquanto se mostre um tanto genérica, um tanto aberta, o emprego dessa regra não dispensa a suficiente motivação nas decisões judiciais. Há mais direitos fundamentais em jogo, ao menos expectativas caríssimas aos demais envolvidos, que são os genitores biológicos e os pretendentes à adoção. É preciso que o profisssional de direito tenha condições de 
identificar as questões jurídicas e dar- lhes tratamento científico, para que os procedimentos sejam mais previsíveis e seguros.

Outro tema intimamente vinculado ao consentimento e à adoção "intuitu personae" é o anonimato ou a possibilidade de revelação. Noutras palavras, a possibilidade de acesso do filho adotivo à verdade sobre sua origem, sua filiação biológica. Muitas vezes a circunstância atua como motivo para a escolha da modalidade da adoção impropriamente designada "à brasileira”, em fraude registrária (quando os adotantes querem privar o adotado de qualquer informação sobre os pais biológicos), ou, em sentido diametralmente oposto, porque a mãe biológica crê que os "padrinhos" que ela própria escolheu concordarão em preservar algum vínculo, que a intervenção judicial ameaçaria.

$\mathrm{O}$ direito a conhecer a própria origem tem status constitucional, embora experimente um retrocesso na atualidade, ao menos no Brasil, com o anteprojeto apresentado pelo IBDFam - Instituto Brasileiro de Direito de Família, para instituir o "parto anônimo", outrora garantido pelas "Rodas dos Enjeitados".

O direito estrangeiro oferece contrapontos interessantes e é objeto de um capítulo específico (capítulo IV).

No capítulo $\mathrm{V}$, oferecemos nosso pensamento sobre algumas questões polêmicas: a possibilidade de adoção de nascituro, o caráter absoluto ou relativo ordem cronológica da inscrição no cadastro dos interessados em adotar e, finalmente, a legalidade das restrições à escolha do perfil da criança desejada pelos adotantes.

Por fim, oferecemos nossas conclusões. 


\section{CAPÍTULO I - NOÇÕES PRELIMINARES}

\section{Terminologia:}

Adoção intuitu personae, ou adoção consensual, é a modalidade de adoção em que os pais biológicos, em geral a mãe biológica, escolhem os adotantes de seu filho.

É possível usar o mesmo termo para as situações em que o pretendente à adoção manifesta a vontade de adotar uma determinada criança ou adolescente, excluindo qualquer outra.

A adoção, que era tradicionalmente conceituada como ato jurídico bilateral, solene e complexo em que os laços de filiação se estabeleciam pela vontade de particulares, deixou de ser mero contrato para adquirir contornos institucionais institucional, pois seu aperfeiçoamento agora exige sentença judicial, de natureza constitutiva.

A Constituição Federal de 1988 previu a assistência estatal às adoções e o ECA, Estatuto da Criança e do Adolescente, Lei 8069/90, de 13 de julho de 1990, Estatuto da Criança e do Adolescente, submeteu a adoção de toda pessoa menor de 18 anos a intervenção judicial. A partir do início da vigência do Código Civil de 2002, em 11 de janeiro de 2003, toda e qualquer adoção reclama forma judicial (art. 1623), não mais se admitindo como título a escritura pública entre particulares.

Nesse contexto, a definição mais explicativa seria a seguinte: adoção intuitu personae é a modalidade de adoção em que os pais biológicos, não a autoridade judiciária, escolhem os adotantes.

As expressões "adoção consensual" e "adoção dirigida" são sinônimas, mas são usadas com menos freqüência.

Prosseguindo, o Dicionário HOUAISS registra a expressão “intuitus personae" com o significado de "em consideração à pessoa do outro". ${ }^{1}$ Para DE PLÁCIDO E SILVA, “intuitu personae”“ é a expressão latina que se traduz por "em consideração à pessoa", e que, na terminologia jurídica, se usa m âmbito dos contratos que se firmam, ou nas obrigações que se contraem, em consideração especial às pessoas.

\footnotetext{
${ }^{1}$ Dicionário Houaiss da língua portuguesa, Rio de Janeiro, Objetiva, 2001, p. 1641.
} 
São obrigações assumidas em função de particulares virtudes ou qualidades especiais do outro contratante, que não comporta substituição. ${ }^{2}$

Se até o advento do ECA a adoção não necessitava da forma judicial, exceção feita à colocação do menor abandonado (art. 28 da Lei 6697, de 10 de outubro de 1979, Código de Menores, adoção simples de menor em situação irregular), não havia motivo para se empregar o qualificativo intuitu personae, pois sobressaía o caráter contratual do instituto. Foi depois do ECA que os profissionais dos serviços psicossociais judiciários (equipes multidisciplinares previstas no art. 150 do ECA) passaram a utilizá-lo mais amiúde; autores modernos como fazem-lhe referência em suas obras (cf. E. GRANATO e M. BERENICE DIAS ) ${ }^{3}$, como também a jurisprudência mais recente.

A adoção intuitu personae não é o mesmo que adoção "pronta", nome que se dá àquelas situações em que os interessados apenas querem regularizar uma situação fática já consolidada, decorrente de entrega informal feita muito tempo antes. Nessa situação, de criança ou adolescente há muito tempo confiada a alguém, a solidez dos vínculos afetivos criados no convívio é decisiva, há pouco espaço para a intervenção judicial, que assume um feitio apenas homologatório e sem relevância maior. Nem há confusão com a adoção "áberta", que, à semelhança do sistema americano, pressupõe necessariamente a continuidade do contato entre genitores biológicos e adotivos, segundo o que ficar acordado.

A este estudo não interessa a adoção de adultos, adolescentes ou crianças de mais de dois ou três anos de idade, mas tão-somente de recém-nascidos e bebês - a língua portuguesa estendeu o uso do substantivo infante a crianças até a puberdade, desviando-se da origem etimológica do vocábulo (do latim "in fans: que não fala ou que ainda não consegue falar"); a língua inglesa ainda conserva o substantivo "toddler" para designar essa faixa etária. A restrição não é aleatória, pois leva em consideração a etapa do desenvolvimento infantil em que as crianças falam e conseguem expressar suas vontades e preferências. Nesse último caso, a tarefa judicial de colocação em lares substitutos, se não é mais simples, obedece ao menos a um critério seguro: a análise dos laços de afeto pré-

\footnotetext{
${ }^{2}$ Dicionário de termos jurídicos, $11^{\mathrm{a}}$ ed., Forense, p. 511: "as obrigações que deles se geram são de prestações pessoais, isto é, somente podem ser exercidas pelas pessoas que as contraem. Têm o caráter personalíssimo. Nesta razão, o intuitu personae assinala, perfeitamente, que o contratante teve a intenção de contratar ou de se obrigar com determinada pessoa, ou em consideração a ela, o que não faria, sabendo que outra poderia substituí-la. Os direitos que se geram dos contratos ou obrigações intuitu personae, em princípio, são inecediveis ou intransmissivel",2.

${ }^{3}$ M. B. DIAS, Manual de direito das famílias, 4a . ed., São Paulo, RT, p. 437, com referência também à vontade de adotar determinada criança, como na situação de vinculação afetiva a crianças abrigadas em instituições onde se trabalha e desenvolve serviço voluntário.
} 
existentes, com a possibilidade de consulta a adolescentes (art. 45, § $2^{\circ}$., do ECA) e a crianças maiores.

Já a adoção "pronta", com o objetivo de regularizar a posse e o status de um filho de criação, por exemplo, não constitui objeto de interesse, uma vez que nessas situações é o tempo, ao criar e estreitar laços de afeto, o fator preponderante para a análise da "conveniência da constituição do vínculo" jurídico ( $\$ 1^{\circ}$. do art. 46 do ECA).

Considerando o interesse na realidade específica da adoção de recémnascidos ou bebês, fazemos uso indistinto, ao longo deste trabalho, das expressões "mãe biológica", "mãe ou pai biológicos" e "parentes biológicos", que devem ser compreendidas como designando a pessoa em condições efetivas de dispor da criança, que na grande maioria das vezes é sua genitora.

\section{O Direito à Convivência Familiar}

Dentre os direitos fundamentais reconhecidos à criança e adolescente ao longo do século XX (Declaração Universal dos Direitos Humanos de 1948, Pacto de São José de 1969, Atos das Assembléias Gerais da Organização das Nações Unidas de 1985 Regras de Beijing, Diretrizes do Oitavo Congresso das Nações Unidas sobre Prevenção do Delito e Tratamento do Delinqüente de 1989, Convenção de Haia de 1993), o direito à convivência familiar sempre recebeu adequada ênfase. A lembrança de famílias destroçadas pela Segunda Guerra Mundial certamente sensibilizou os autores da Declaração Universal dos Direitos Humanos de 1948. Tanto quanto se admite hoje que a essência dos direitos humanos é o direito a ter direitos, na conhecida expressão de $\mathrm{H}$. ARENDT $^{4}$, pode-se dizer, em analogia, que o direito primordial da pessoa em formação, criança ou adolescente, é o direito de crescer em família, base e pressuposto à aquisição de todos os demais direitos - à integridade física e psíquica, à liberdade, à educação, à proteção contra toda forma de opressão etc. A essência dos direitos da criança, assim, é o direito a ser recebido e amado como filho. Para D.WINNICOTT ${ }^{5}$, a família constitui espaço privilegiado de convivência, de iniciação e introdução às normas sociais.

\footnotetext{
${ }^{4}$ H. ARENDT, As origens do totalitarismo, $2^{\mathrm{a}}$. ed., Rio de Janeiro: Documentário, 1979. A autora assevera que o vínculo de cidadania, pessoa-Estado, é condição imprescindível para a fruição de direitos.

5 Donald Woods WINNICOTT (1897-1971), pediatra e psicanalista inglês, autor de 'Desenvolvimento Inicial Primitivo" (1945) e extensa obra sobre desenvolvimento infantil. Afirmou que a qualidade dos cuidados maternos no início da vida é responsável pela saúde mental do indivíduo. Na história da psicanálise infantil, também merecem destaque os trabalhos das pioneiras austríacas Anna Freud e Melanie Klein, do
} 
A Declaração sobre os Direitos das Crianças foi adotada pela Assembléia Geral da ONU em 20 de novembro de 1959 e é conhecida como Declaração Universal dos Direitos da Criança porque os enuncia em 10 princípios, dois quais o seguinte é o sexto:

" 6 . Para o desenvolvimento completo e harmonioso de sua personalidade, a criança precisa de amor e compreensão. Criar-se-á, sempre que possível, aos cuidados e sob a responsabilidade dos pais e, em qualquer hipótese, num ambiente de afeto $e$ segurança moral e material; salvo circunstâncias excepcionais, a criança de tenra idade não será apartada da mãe. À sociedade e às autoridades públicas caberá a obrigação de propiciar cuidados especiais às crianças sem família e àquelas que carecerem de meios adequados de subsistência. É desejável a prestação de ajuda oficial e de outra natureza em prol da manutenção dos filhos de famílias numerosas."

Apenas a título de exemplo, as Diretrizes de Riad, fruto do $8^{\circ}$. Congresso das Nações Unidas sobre Prevenção do Delito e Tratamento do Delinqüente, elegem o ambiente familiar estável e firme como objetivo maior da ação governamental. As Diretrizes prevêem que, no caso de fracassar a família de natural na oferta desse ambiente, devem os governos promover o acolhimento familiar e a adoção (art. 13).

A Convenção de Nova York sobre os Direitos da Criança de 1989, adotada pela Assembléia Geral das Nações Unidas em 20 de novembro de 1989 e ratificada pelo Brasil em 24 de setembro de 1990, dispõe nos seus consideranda:

Convencidos de que a família, unidade fundamental da sociedade e meio natural para o crescimento e o bem-estar de todos os seus membros e, em particular das crianças, deve receber a proteção e assistência necessárias para que possa assumir plenamente suas responsabilidades na comunidade;

Reconhecendo que a criança, para o desenvolvimento pleno e harmonioso de sua personalidade, deve crescer em um ambiente familiar, em clima de felicidade, amor e compreensão;

Inquestionável o direito do menor a crescer em família, preocupação que constitui o cerne da doutrina da proteção integral. Ainda que o art. 227 da Constituição Federal de 1988 tenha arrolado o direito à convivência familiar como o penúltimo de uma série, isso não significa que seja menos importante na gradação dos direitos. Na interpretação das normas, o critério "topográfico" não é o mais adequado, pois o contexto é que se mostra fundamental. A compreensão da magnitude desse direito decorre

inglês John Bowlby e da francesa Françoise Dolto. Esta última, discípula de Lacan, autora de "Tudo é Linguagem" e "Adoção - Destinos de Crianças", é precursora do estudo da linguagem dos bebês e formulou a teoria da importância vital do acolhimento nos primeiros dias de vida ("accouchement"). 
forçosamente do "caput" do art. 226, que enuncia que a família é a base da sociedade, conferindo- lhe a especial proteção do Estado, de seus $\S \S 6^{\circ}$. e $7^{\circ}$, que dispõem sobre assistência ao planejamento familiar e prevenção da violência na família, e muito particularmente dos parágrafos $3^{\circ}$, VI, e $5^{\circ}$, no sentido de que o acolhimento sob guarda será estimulado e a adoção, assistida pelo Poder Público.

Com efeito, o sistema de proteção aos direitos infanto-juvenis constrói-se principalmente a partir de políticas eficazes de prevenção ao abandono e reinserção familiar (reintegração ou devolução da criança abandonada ao lar de origem), mas só será completa se existir adequado estímulo às adoções, à criação de famílias adotivas idôneas, bem estruturadas e conscientes, e, na impossibilidade de reinserção na família biológica ou de adoção, de ações que objetivem o encurtamento da permanência em instituições e até a substituição destas por famílias acolhedoras. Repita-se: o direito a crescer em família é o fundamental, precedendo ao direito de ser mantido na família de origem e aos direitos ou interesses de quaisquer adultos envolvidos. É a interpretação devida ao artigo 19 do ECA.

Portanto, além dos programas de proteção à família, que incluem acesso ao planejamento familiar, proteção do trabalho e da saúde da gestante, garantia da licençamaternidade e universalização da educação infantil (creche e ensino pré-fundamental), cabe ao Estado aperfeiçoar os mecanismos para constituir famílias por adoção.

A compreensão de que a vida nas instituições é artificial e vazia de significado está se ampliando no Brasil. Crescer numa instituição significa adaptar-se a rotinas de impessoalidade e formar somente laços precários, efêmeros, com as pessoas que a servem (que prestam, na expressão de F. DOLTO, “cuidados mercenários múltiplos $e$ sucessivos" ${ }^{\text {") }}$. A interação emocional é insuficiente para o desenvolvimento psíquico saudável. É por isso que, ao mesmo tempo em que aboliu os termos "orfanato" e "asilo" (reminiscência dos tempos de "Oliver Twist", e usada para designar as "instituições totais", locais de internação, ou seja, onde menores em grande quantidade recebiam moradia e escola, com pouquíssimas saídas externas), substituindo-o por entidade de abrigo, o ECA ordenou que a institucionalização - isto é, a ruptura do convívio familiar se faça em caráter excepcional e provisório (art. 19).

A necessidade de melhor compreender o instituto e de algum modo iluminar a interpretação da real vantagem para o adotado (expressão que o Código Civil de 2002 substituiu por "efetivo benefício para o adotando" e o Projeto de Lei 1756/03, que dispõe

\footnotetext{
${ }^{6}$ Destinos de crianças, Martins Fontes, 2006, p. 164.

${ }^{7}$ Obra de ficção publicada por C. DICKENS em 1838.
} 
sobre a Lei Nacional da Adoção, recuperou), insere-se na preocupação constitucional com a garantia do direito à convivência familiar, de acordo com a regra da consideração dos interesses superiores da criança, posta na Convenção Internacional que o Brasil ratificou em 1990, ao mesmo tempo em que era promulgado o ECA.

O direito a crescer em família sobreleva o direito a crescer na família de origem; compreende-se hoje que garantir o direito a crescer em família idônea, capaz de propiciar ambiente adequado ao pleno desenvolvimento das potencialidades da criança, constitui a ambição maior da doutrina da proteção integral.

\section{A repersonalização do direito de família}

Está-se assistindo ao fenômeno crescente da repersonalização do direito de família, às vezes designado de despatrimonialização. A Constituição Federal de 1988 sedimentou, como corolário do princípio da dignidade da pessoa humana, o reconhecimento da família em suas variadas formas (e não apenas a família constituída partir do casamento) e a idéia da desbiologização da paternidade, com a isonomia entre os filhos, a implicar o caráter pleno de toda adoção ulterior. Em termos normativos, definitivamente ficou para trás a idéia de inferioridade dos filhos adotivos em relação aos filhos legítimos.

Mudam os tempos e os costumes, muda a conformação da família; a partir da observação, os doutrinadores tecem considerações interessantes: L. FACHIN aponta a predominância atual de relações de afeto, de solidariedade e cooperação, dizendo que " $d a$ superação do antigo modelo da grande família, na qual avultava o caráter patriarcal e hierarquizado da família, uma unidade centrada no casamento, nasce a família constitucional, com a progressiva eliminação da hierarquia, emergindo uma restrita liberdade de escolha; o casamento fica dissociado na legitimidade dos filhos" ${ }^{8}$. G. TEPEDINO descreve a passagem da 'família-instituição" para a "família-instrumento", voltada "à formação e ao desenvolvimento da personalidade de seus componentes, nuclear, democrática, protegida na medida em que cumpra o seu papel educacional, e não qual o vínculo biológico e a unicidade patrimonial são aspectos secundários" 9 .

\footnotetext{
${ }^{8}$ Mudanças sociais no direito de família", in "Aspectos Controvertidos do Novo Código Civil”, A. ALVIM e outros, RT, 2003, p. 444.

${ }^{9}$ Temas de Direito Civil, $2^{\mathrm{a}}$. ed., Renovar, p.421.
} 
Plural e flexível, a família pós-moderna passou a ter como principal função o "suporte emocional do indivíduo, em que há flexibilidade e, indubitavelmente, mais intensidade no que diz respeito aos laços afetivos" $" 10$. A família, assim, atua como uma plataforma emancipatória de seus integrantes, na busca do livre desenvolvimento da personalidade e da felicidade própria de cada um.

Ganhou importância o elemento afetivo, considerando-se adequado que entre pais e filhos se estabeleçam relações de intimidade e carinho; relações que, antes marcadas pelo senso de hierarquia e autoridade, hoje buscam o diálogo e o consenso, ou seja, se aproximam do ideal democrático.

A Constituição Federal de 1988, ao estabelecer que "o Estado assegurará a assistência à família na pessoa de cada um dos componentes que a integram" ( $\$ 8^{\circ}$ do art. 226, primeira parte), introduziu um contexto de subjetivismo, de valorização do indivíduo diante da família. Pode-se dizer que o ordenamento jurídico brasileiro, no limiar do século XXI, acabou por incorporar a mentalidade que presidiu Código Civil francês, que dedica um mesmo livro ao direito da pessoa e ao direito de família, dando a entender que são objetividades jurídicas indissociáveis.

A vida na pós-modernidade conheceu também o fenômeno do avanço científico sobre a reprodução humana, que difundiu tecnologias sofisticadas como a inseminação artificial e fertilização in vitro. A luta pela fertilidade, a cessão de óvulos e de útero ("surrogate mother", sub-rogação de ventre ou "barriga de aluguel"), tudo parece conspirar contra a adoção como escolha de vida e de integração da família.

Como era de se prever, o futuro da adoção foi questionado. Mas é a característica flexível e plural da família pós-moderna que mantém a adoção em seu lugar de destaque: ao lado dos que sofrem com a impossibilidades física de gerar, o desejo de adotar filhos existe para um grande contingente de casais maduros, celibatários e casais homossexuais, a quem se reconhece, tanto quanto a qualquer outra pessoa, o direito à busca da felicidade.

\section{Evolução histórica da adoção - da Cidade Antiga às Ordenações do}

\section{Reino}

${ }^{10}$ Vide M. DIAS, op. cit., p. 40. 
FOUSTEL DE COULANGES nos descreve a família na antigüidade como o núcleo que celebra os mesmos deuses e antepassados e compartilha das ofertas e repastos fúnebres. É a religião familiar que confere a unidade o parentesco. Admitiam-se estranhos à família por meio da adoção, mas apenas para que não se corresse o risco terrível de morrer sem descendentes. O adotado repudiava os deuses da família de origem, para em seguida adotar os da nova família. Nesse estado de coisas, os laços de afeto eram secundários, tanto assim que, ao se casar, as mulheres deixavam a família de origem. As filhas mulheres não podiam herdar.

Nessas sociedades, ao pai de família cabia o direito de vida e morte sobre os filhos e agregados.

Em Roma, o pater familias, desde o momento do reconhecimento do filho que era necessariamente o filho nascido de justas núpcias -, em que o tomava nos braços ("tollere liberum"), exercia poder de vida e morte sobre ele, componente que era do pátriopoder. Esse poder quase absoluto só cessava com a capitis deminutio própria, que equivalia à morte, ou ainda com a emancipação do filho, o casamento cum manu da filha e a adoptio do alieni juris (que se fazia mediante venda fictícia do filho a outrem).

A adoção como instituto servia ao interesse de adultos, não ao de crianças. Crianças abandonadas tornavam-se escravas e não adotadas.

Existia outra forma de adoção, a "adrogatio", que recaía sobre pessoa sui juris do sexo masculino e púbere, que, uma vez adotada, perdia a independência e a capacidade jurídica de gozo. A solenidade exigia que o povo se reunisse em comício; em tempos mais recentes, bastavam 30 lictores (30 antigas cúrias).

MOREIRA ALVES considera que a adoção, em qualquer de suas formas, adoptio ou adrogatio, constituía meio de ingresso na família "proprio iure", com a sujeição à "patria potestas" "11. Embora diversos os institutos, seus efeitos se aproximavam.

$\mathrm{Na}$ legislação de Justiniano, a adoptio acabou por aproximar o adotado do filho nascido de um casamento legítimo.É o possível testemunho de uma individualização, de uma cristianização do direito, em que a família não mais se assenta sobre a potestas apenas. $^{12}$

Com o Cristianismo, a situação da família mudou; o pater famílias já não exercia direito de vida e morte sobre os filhos e agregados, embora se admitissem castigos

\footnotetext{
${ }^{11}$ J.C. MOREIRA ALVES, Direito Romano, v II, Forense, 1992, p. 295.

${ }^{12}$ ROUMY, Franck, L'Adoption dans Le Droit Savant du XIIe au XVIe. Siècle, L.G.D.J, 1998, p.89
} 
físicos e outros agravos. A subordinação dos filhos se estendia até o casamento ou a formação de economia própria.

A adoção caiu em desuso na Idade Média, uma vez que a transmissão dos títulos nobiliárquicos se fazia juris sanguinis., motivo pelo qual o ato de adotar representaria voluntária e artificial interferência nas linhas sucessórias.

A. CHAVES, porém, nos dá a notícia da subsistência de uma forma de adoção assemelhada à adoptio minus plena do direito romano, que servia a satisfazer, em quem não tinha filhos do próprio sangue, o sentimento cristão de paternidade e proteção ${ }^{13}$. Aperfeiçoava-se por escrito, carta ou testamento.

Entre os germanos a adoção fazia-se pelas armas e para as armas, com o propósito de perpetuar as campanhas de guerra do adotante; constituía-se numa cerimônia de transmissão de armas diante de uma assembléia. Ao se desenvolver, o instituto tomou as feições de pacto hereditário.

Entre os francos a adoção era permitida aos homens sem filhos, com o propósito de transmitir a herança, mas pouco praticada. Um instituto similar, a afiliação, pressupunha a existência de filhos próprios e tinha vez no casamento de dois viúvos com filhos, ou no casamento de dois irmãos com duas irmãs.

Somente na era napoleônica a adoção veio a ser regulamentada na França, sujeita à condição do imitatio naturae (homens com mais de cinqüenta anos, sem filhos nem descendentes legítimos, tendo por objeto adulto no mínimo 15 anos mais novo, a quem tivesse prestado assistido por no mínimo seis); foram então disciplinadas a adoção testamentária e a adoção remuneratória.

Em Portugal, as Ordenações Afonsinas, Manuelinas e Filipinas contêm poucas disposições sobre a adoção, que tomou o nome perfilhamento, confundindo-se com a legitimação adotiva.

\section{Evolução histórica da vida em família - Do Antigo Regime até a Pós-}

\section{Modernidade}

No Antigo Regime, a prática generalizada entre as famílias de algum poder aquisitivo era a entrega de infantes a amas-de-leite, que os criavam no campo até os cinco anos de idade. A mortalidade infantil era altíssima, tanto assim que a Enciclopédia revista

\footnotetext{
${ }^{13}$ Adoção e legitimação adotiva, RT, 1966, p. 36.
} 
(atualizada aos tempos de hoje) faz referência a amarga reflexão de Montaigne: "minhas crianças morrem todas ainda com a ama de leite"14.

C. de LA RONCIÈRE, historiador, dá conta de que, na alta Idade Média, as crianças toscanas dos extratos mais abastados na viviam fisicamente separadas de suas mães. ${ }^{15}$ Aos filhos de camponeses ou vilões pobres a sorte incluía infanticídios e abandono, além de alta mortalidade na época das pestes (1348-1430). A descrição é terrível: "desde esse momento, e mais ainda a partir do século XV, o infanticídio (por sufocação) não é mais um fenômeno excepcional, e os abandonos tornaram-se suficientemente numerosos para levar à criação de asilos (San Gallo, Innocenti, 1445, Florença), geradores por sua vez de novos abandonos. Os bebês, sobretudo do sexo feminino, são muito frágeis, por vezes muito pouco desejados, para que o apego real que se tem por eles resista às graves coerções da pobreza" $"$.

Foi a partir do estudo dessa época e da obra de Jean-Jacques ROUSSEAU (autor de "Emílio", 1762, tratado filosófico sobre a educação e o tratamento das crianças), precursor da mudança de costumes, que a filósofa francesa E. BADINTER, ao publicar em 1985 o livro "Um amor conquistado. O Mito do Amor Materno", causou intensa comoção, ao apresentar a idéia de que o amor materno não é um instinto nem um imperativo biológico da mulher, mas um comportamento cultural, ou seja, que responde fundamentalmente à cultura de cada época e lugar.

Para ilustrar as práticas do Antigo Regime, veio a denúncia de que o próprio ROUSSEAU abandonou cinco de seus filhos, havidos com a serviçal Thérèse de Vaisseau, deixando-os na roda dos enjeitados.

A relação mais estreita com os filhos, "mais sentimental", só se deu a partir do Renascimento, com surgimento do ideal do amor romântico e da concepção da família como lugar de aconchego e ternura. Somente então a criança pequena passou a ser valorizada, e a preocupação com o aleitamento materno surgiu. Trata-se do fenômeno que se convencionou chamar, entre historiadores e sociólogos, de "invenção da maternidade".

\footnotetext{
${ }^{14}$ Vide o capítulo Criança e Adulto, por S. PARRAT-DAYAN e J. VONÈCHE, in, As palavras no tempovinte e seis vocábulos da encyclopédie reescritos para o ano 2000. (D. DE MASI e D. PEPE (org.), Rio de Janeiro: José Olympio, 2003, p. 85).

${ }^{15}$ Quadros: A vida privada dos notáveis toscanos, in P. ARIES e G. DUBY, História da vida privada $2-D a$ Europa medieval à renascença”: "As crianças pequenas partilham em parte o destino de sua mãe. Em parte apenas, pois na burguesia os bebês são excepcionalmente amamentados por sua mãe. São confiados a amasde-leite, das quais apenas um quarto (23\%) são instaladas na casa dos patrões. Na porção de três em quatro, os bebês passam todos os seus primeiros meses longe de sua casa, e até mais, já que 53\% deles não são retomados por sua senão após dezoito meses, pelo menos. Um memorialista, falando de seu pai, conta que ele o fez permanecer na casa de sua ama de leite até os doze anos! p. 223/224.

${ }^{16}$ Op. cit., p. 220.
} 
Não é difícil relacioná-lo ao fenômeno da "invenção da infância”, tese de P. ARIÈS, que divide a história da infância em dois momentos, o primeiro caracterizado pela ausência do sentimento de infância, e o segundo, iniciado no século XVIII, caracterizado por esse sentimento. Segundo a Enciclopédia revista, "á emergência da infância como objeto de preocupação social coloca-se então em estreita relação com a exigência de salvaguardar a população adulta e de assegurar, desta maneira, o futuro, econômico ou militar, de uma nação" 17 .

Na Inglaterra da Revolução Industrial, já fortemente influenciada pelas idéias do demógrafo e economista T. MALTHUS, que pregava o controle populacional por meio da abstinência sexual, "uma família grande, em vez de ajudar na luta pela sobrevivência, passou a ser vista como um fardo insuportável"18.

A partir daí, os padrões da interação pais-filhos foram substancialmente alterados para todas as classes sociais. A última parte do século XX assistiu ao declínio do poder patriarcal, em boa parte explicado pela inserção da mulher no mercado de trabalho , A interação mães-filhos aumentou à medida que as famílias iam ficando menores, e cada criança começou a ser percebida como especial. Como declarou M. RYAN, o centro da família deslocou-se "da autoridade patriarcal para a afeição maternal"19.

A relativa tranqüilidade do pós-guerra e o fenômeno do baby boom tiveram grande importância na valorização da vida doméstica. Nos anos 50, os americanos ficaram obcecados por bebês, e a imensa vendagem do livro do Dr. Benjamin Spock sobre puericultura simboliza esse sentimento. A família ideal seguia um modelo rígido: o homem saía para trabalhar, a mãe cuidava da casa, dois ou três filhos. Com o passar do tempo, esse modelo ruiu. Aumentaram os divórcios e as segundas e terceiras uniões, com novas espécies de parentesco (co-irmãos, por exemplo); as uniões homossexuais se tornam públicas. $^{20}$

\footnotetext{
${ }^{17}$ DE MASI, op. cit., p. 96.

${ }^{18}$ A. MACFARLANE, História do casamento e do amor - Inglaterra 1300-1840, São Paulo, Companhia das Letras, 1990, p. 77.

${ }^{19}$ M. RYAN, The cradle of the middle class, Cambridge, University Press, 1981, p. 102.

${ }^{20}$ E. MAY, Myths and realities of the american family", in P. ARIÉS e G. DUBY (org.) - A history of private life V-Riddles of identity in modern times", HUP, 1991, p. 590: "In spite of the persistence of many of its features the American family continues do evolve. The wide diversity os family structures that exist today has profoundly challenged beliefs about the 'ideal' ou 'normative' family. Divorce has became so common that today's families are frequently arranged around relationships between ex-spouses and stepparents, stepsibilings and quasi-in-laws. Marriage is no longer the determining factor in family life, as couples live together, and as single-parent families become increasingly common. Even parenthood is being defined in new ways. With recent developments in such areas as open adoption and new reproductive technologies, children can have up to five "natural" parents: genetic mother, birth mother, nurturing mother, genetic father (or sperm donor), and nurturing father."
} 
A criança e suas necessidades peculiares tornaram-se visíveis ao longo do século XX; no âmbito público, os manuais de puericultura deram lugar a estudos sobre a psicologia da criança, subsídios para a legislação e para a reforma de serviços públicos. Nesse aspecto, a obra do psicanalista inglês J. BOWLBY (1907-1990), autor da "attachment theory" (ou teoria do vínculo, em tradução livre), que afirma a nocividade da institucionalização de crianças, tenha sido talvez a que exerceu maior influência, pois propiciou mudança nas mentalidades e modelos e promoveu reestruturação radical dos serviços de assistência à Infância na Inglaterra e nos Estados Unidos, países que substituíram praticamente todas as instituições (lares, reformatórios, asilos, abrigos, orfanatos, etc.) pelo sistema de "foster care” (famílias substitutas temporárias).

\section{Abandono e entrega de filhos no Brasil - base cultural}

$\mathrm{Na}$ formação da sociedade brasileira destacam-se os seguintes elementos, capazes de explicar por que o abandono e a entrega de filhos são tão disseminados e até hoje aceitos com naturalidade: a presença ibérica católica, em que o sacramento do batismo e a figura dos padrinhos ocupavam posição central; a miscigenação do português com o índio e negro, que resultava em altíssimo índice de uniões à margem do casamento, e bem assim de prole não reconhecida (“bastarda”); a cultura escravocrata, que, entre outros aspectos, submetia os filhos dos escravos aos desígnios do senhor e permitia que fossem separados de suas mães a partir dos sete anos de idade; e, finalmente, a libertação dos escravos como ocorreu, a criar uma legião de "agregados".

A historiadora M. DEL PRIORI conclui: "enfim, o infanticídio, o abandono ou circulação de crianças pequenas entre vizinhas e comadres à espera de dias melhores nas vidas de suas mães eram uma constante no cotidiano das mulheres da Colônia"21.

Encontram-se muito enraizadas, no imaginário popular, as figuras do filho de criação ou do irmão de criação, aqueles que alguém "pegou para criar". Crianças dadas ou "doadas" a famílias mais abastadas viam-se por toda a parte

G. FREYRE, autor da mais conhecida obra de antropologia social no Brasil, faz inúmeras referências a filhos de criação, especialmente em Casa Grande \& Senzala e Sobrados e Mucambos ${ }^{22}$.

\footnotetext{
${ }^{21}$ Ao sul do corpo, José Olympio, Rio, 1993, p.78.

22 "Observemos - de passagem - que a figura do padrinho ou da madrinha no sistema patriarcal brasileiro é assunto que está a merecer estudo à parte, pois nessa figura tanto se expandiu o patriarcalismo em afirmações de poder ou de funções tutelares como se compensou de frustrações de puro paternalismo ou maternalismo. Este chegou a parecer matriarcalismo quando, na verdade, a mãe - principalmente quando
} 
Em Casa Grande \& Senzala encontramos a descrição de casas-grandes pululando de "mulequinhos", em quantidade. Estrangeiros em visita espantavam-se com o fato, como Maria Graham na visita ao Engenho dos Afonsos. "Aí viu Maria Graham crianças de todas as idades e de todas as cores comendo e brincando por dentro da casagrande; e tão carinhosamente tratadas como se fossem da família". ${ }^{23}$

Poucas eram as exceções à entrega de filhos a padrinhos abastados ou a pessoas conhecidas. Na época em que a gravidez fora do casamento acarretava grave estigma social à mulher, existia a prática de ocultá-la e abandonar (expor) o recémnascido, muitas vezes se servindo da "Roda dos Enjeitados", instituição caritativa que assegurava o anonimato de quem ali deixasse a criança. Extinta a Roda no início do século passado, e praticamente desaparecido o estigma da mãe solteira nos dias de hoje, a entrega ou "doação" de filhos se resolvia no âmbito privado, praticamente sem recurso ao Poder Público.

Sobre as rodas dos enjeitados ou dos expostos, esclareça-se que se trata de um sistema antiqüíssimo, um engenho a serviço do anonimato do expositor, para assim ocultar a desonra de mulheres solteiras, adúlteras, viúvas, noviças e freiras. A "roda" originalmente designava a caixa cilíndrica de madeira, aberta de um lado só, incrustada nas paredes de conventos de reclusas na Europa. A caixa girava sobre seu próprio eixo, de modo que deixava entrar cartas e medicamentos para as freiras, ao mesmo tempo em que impedia a visão do lado de fora. Muitos bebês eram abandonados nessas rodas.

R. VAINFAS nos dá a notícia de que em 1198 foi instalada, no Hospital do Espírito Santo em Roma, a primeira roda especialmente destinada a recolher crianças; a partir daí, "roda" tornou-se prática corrente nos hospitais a partir do século XV (nos países de língua inglesa, conhecida como "foundling wheel"). Em Portugal, as Santas Casas da Misericórdia assumiram a incumbência de criar os enjeitados. No Brasil, as primeiras instituições para os enjeitados (“Casa dos Expostos", "Depósito dos Expostos", "Casa da Roda", "Roda") foram criadas em 1726, na Bahia, e em 1738, no Rio de Janeiro. Nas demais cidades, os infantes eram deixados com amas-de-leite (sistema conhecido como "colocação familiar") contratadas pelas câmaras ou pelas Misericórdias. A

masculinóide - apenas fez as vezes de pai ausente, fraco ou morto - mas nem sempre - esquecido - como no caso da senhora do Engenho Maçangana, madrinha de Joaquim Nabuco. Deste pernambucano a formação da personalidade foi, evidentemente, marcada mais pela madrinha rica-absorvente e desejosa de substituto do marido morto - que por pai ou por mãe." (Sobrados e mucambos, 14a ed., São Paulo, Global, 2003, p. 407).

${ }^{23}$ Casa-grande \& senzala, 19a. ed., Rio de Janeiro, José Olympio, 1978, p.375. 
mortalidade era altíssima (mais da metade morria até os três anos), e por isso o abandono de crianças em lugares públicos recrudesceu. Essa conduta era motivo de forte crítica social, pois acarretava risco à vida de um inocente ainda não batizado, que morreria pagão.

Praticado em larga escala, os historiadores atuais se dividem quanto às causas predominantes para o fenômeno do abandono, se a pobreza, se a necessidade de ocultar a desonra da mãe ("honoris causa") ou, na vigência da escravidão, a intenção de libertar os filhos do cativeiro (no Brasil, uma lei de 1775 tornava livres as crianças enjeitadas, enquanto que a Lei do Ventre Livre somente veio a ser promulgada em 1871) 24 .

Em comentário sobre a instituição, o historiador E. PASSETO ilustrou os altos índices de mortalidade de crianças com o seguinte relato do Imperador Pedro I à Assembléia Constituinte, em 3 de maio de 1823: 'A primeira vez que fui à Roda dos Expostos, achei, parece incrível, sete crianças com duas amas; sem berço, sem vestuário. Pedi o mapa e vi que em 13 anos tinham entrado perto de 12 mil e apenas tinham vingado mil, não sabendo a Misericórdia verdadeiramente onde elas se achavam". ${ }^{25}$

A "roda dos enjeitados" de São Paulo somente foi desativada em 1927.

Nesse contexto histórico, que justifica a falta de confiança na única instituição oficial que admitia crianças sem lar, a prática de entregar filhos a pessoas conhecidas tornourse, sem dúvida, culturalmente aceita. A necessidade, o discurso de que é melhor "doar" a quem se sabe que irá cuidar bem do que 'fazer sofrer", são os motivos que as mães apresentam às Varas da Infância e Juventude, quando se apresentam ao lado de seus escolhidos.

Um misto de pena e atenuada reprovação social acabam por envolver a atitude dessas mães. Quanto à pessoa ou casal que se dispõe a receber a criança, é quase sempre vista como inequívoca benfeitora, mesmo se se tenha apressado em levar o recémnascido da própria maternidade, sem maiores questionamentos morais.

Assim, as vicissitudes sociais e econômicas, aliadas à histórica importância da figura do padrinho - o eleito dos pais -, criaram na mulher brasileira a noção de que é sua a tarefa de dispor do destino do filho que traz no ventre e não pode criar, e de que deve pessoalmente assumir a tarefa de procurar, mesmo que com o auxílio de intermediários, as pessoas em condições adequadas de criá-lo. Esse sentimento vigora ainda hoje e a impede de ao menos voltar os olhos para o Estado, que se materializa nos departamentos de

\footnotetext{
${ }^{24}$ R. VAINFAS (dir.), Dicionário do Brasil colonial (1500-1808), Rio de Janeiro, Objetiva. 2000.p. 512-513.

${ }^{25}$ M. DEL PRIORE, História das crianças no Brasil, Contexto, 1999, São Paulo, p.348.
} 
promoção social mantidos pelo Poder Executivo ou das Varas Judiciais da Infância e Juventude.

Tão arraigada na vida socialé a entrega de filhos para que sejam criados por terceiros, que o Manual de Orientação aos Psicólogos e Assistentes Sociais do Tribunal de Justiça de São Paulo faz referência a ela mediante emprego da expressão "adoção natural".

A prática impropriamente designada "adoção à brasileira" impropriamente porque dá a entender que nós brasileiros constituímos uma não de fraudadores, o que não se pode aceitar -, diz respeito às adoções concretizadas mediante falsa declaração no registro de nascimento e era comuníssima, "o que todo mundo fazia", a despeito da criminalização da conduta (hoje objeto do artigo 242 do Código Penal).

Nesse aspecto, e compreendido que uma realidade cultural não muda do dia para a noite, a idéia de abolir de todo a vontade da mãe na escolha dos pretendentes pode se mostrar contraproducente do ponto de vista da proteção da criança, ante a conseqüência previsível da reiteração da entrega, da segunda vez de modo clandestino.

Outra conseqüência perversa é a registrada por M. BERENICE DIAS: "Mesmo que a mãe entregue o filho a quem lhe aprouver, o Ministério Público ingressa com pedido de busca e apreensão, e a criança acaba sendo institucionalizada. Lá permanece até findar o processo de destituição do poder familiar, o que freqüentemente chega a demorar anos. Só depois a criança é entregue em adoção ao primeiro inscrito da lista que eventualmente ainda a queira, pois, de modo geral, todos desejam adotar crianças de pouca idade". P. $438^{26}$

Observa-se, por fim, que os aspectos sociais e psicológicos da entrega de filhos têm recebido maior atenção recentemente, dando origem a estudos sistemáticos nas áreas da Psicologia e do Serviço Social.

\section{Espécies de Filiação}

Tradicionalmente, as espécies de filiação são a natural, também designada biológica, e a civil ou adotiva. O Código Civil de 2002 instituiu um tertium genus: a filiação decorrente de fertilização artificial heteróloga feita com o consentimento do

\footnotetext{
${ }^{26}$ Op. cit., p. 438.
} 
marido (art. 1597, V), que é ao mesmo tempo natural e civil. Para designar essa realidade aparentemente paradoxal, CAIO MÁRIO cunhou a expressão "filiação social"27.

Há tempos doutrina a jurisprudência aludem à filiação afetiva ou psicossocial, que corresponde à filiação decorrente de registro de filho alheio como próprio.

Tão disseminada era a prática, que todos a conhecem como "adoção à brasileira". No mais das vezes envolvia o companheiro de uma mulher grávida de terceiro ou com filhos pequenos, sem o reconhecimento paterno. Esse companheiro, ao invés de adotar a criança, simplesmente a registrava como se sua fosse, em geral para evitar preconceitos e melhor protegê-la, oferecendo o gesto como prova de amor irrefutável.

Com as mudanças culturais, e particularmente com a mudança da moral sexual média, que passou a admitir o sexo antes do casamento e as uniões múltiplas, a conduta não mais se justifica. Atualmente está prevista no art. 242 do Código Penal (cujos nomen juris são parto suposto e registro de filho alheio como próprio, sendo-lhes cominada pena muito mais branda do que a da falsidade ideológica). São inúmeros os casos em que, rompido o convívio com a mãe, o autor do registro pretende anulá-lo, sob argumento da inexistência do vínculo biológico, geralmente com o propósito de se subtrair ao dever de sustento. Mas jurisprudência consolidou o entendimento de que, ausente erro ou vício de vontade, a anulação do registro não é possível, devendo subsistir em homenagem à paternidade moral ou afetiva. No fim das contas, o perfilhamento nessas condições pretendeu substituir a adoção, que é irrevogável. Outras situações envolvem disputas sucessórias, em que irmãos, filhos naturais, querem excluir o reconhecido da herança. Nesses casos, a jurisprudência não reconhece a legitimidade ativa para propor a demanda, que envolve direito personalíssimo.

Outra espécie aventada de adoção seria a "presumida", ou seja, resultante do amor devotado ao "filho de criação". Não há absolutamente como reconhecê-la, pois os efeitos do perfilhamento são tão sérios, sobretudo os efeitos morais, que não se dispensa manifestação de vontade expressa. A esse respeito, G. LACERDA já se manifestou no sentido da inexistência de adoção tácita, uma vez que a lei repele a posse de estado como fato constitutivo ${ }^{28}$.

\footnotetext{
${ }^{27}$ Instituições de direito civil, $11^{\mathrm{a}}$. ed., Forense, p. 311.

${ }^{28}$ Direito de família, Forense, 2000, p. 112/114: menção a adoção presumida no v. acórdão coligido como Caso $n^{\circ} .18$.
} 
$\mathrm{Na}$ sistemática anterior ao ECA, os menores estavam sujeitos a duas espécies de adoção, "adoção plena" e "adoção simples". A adoção simples era formalizada por escritura pública (art. 375 do Código Civil de 1916) e instituía parentesco limitado às pessoas do adotante e do adotado. Assim, não havia real integração do adotado à família do adotante.

Maior reconhecimento jurídico e social advieram à adoção na década de 1970, quando J. B. VILLELA ofereceu importante construção doutrinária, a que denominou desbiologização da paternidade. VILLELA apontou na decisão de adotar um exercício mais efetivo do direito de escolha do indivíduo. Concluiu o professor mineiro que "a paternidade adotiva suplanta, em origem, a procedência biológica, pelo seu maior teor de determinação", ou seja, que a paternidade adotiva traduz uma efetiva escolha do indivíduo $^{29}$.

\section{Evolução histórica da adoção no direito positivo brasileiro}

As Ordenações do Reino, que em matéria de direito de família vigoraram até o advento do Código Civil de 1916, faziam poucas referências a filho adotivo, principalmente na questão sucessória.

É por isso que LAFAYETTE ${ }^{30}$, ao tratar do direito de família sob o Império, em 1889, criticou asperamente suas fontes, adjetivadas de ‘em pobres e mesquinhas" (“acêrca dos Direitos de Família, particularmente, não temos lei que regulasse a matéria sob um plano sistemático"), que exigiam que as muitas e graves lacunas fossem preenchidas de acordo com o direito consuetudinário e o direito romano, corrigido segundo declarações legais.

A Constituição Política do Império do Brasil (1824) não se oupava do tema. As Constituições republicanas não fizeram referência a adoção ou filho adotivo. A Constituição da República de 1891 dispôs sobre unicamente sobre casamento - casamento civil, único reconhecido. A Constituição de 1934 pôs a família, sempre constituída pelo casamento civil indissolúvel, sob proteção especial do Estado e dispôs sobre o reconhecimento de filhos naturais; proibiu o trabalho aos menores de 14 anos. A Constituição de 1937 repetiu tais disposições, instituindo benefício para as famílias

\footnotetext{
${ }^{29}$ Desbiologizaçao da Paternidade, in Revista da Faculdade de Direito da UFMG 21/401-419, 1979

${ }^{30}$ Direitos de família, $4^{\text {a }}$. ed., Freitas Bastos, 1945, p. 14.
} 
prolíficas (art. 124: “às famílias numerosas serão atribuídas compensações na proporção dos seus encargos"); previu a facilitação do reconhecimento de filhos naturais e equiparação dos direitos aos dos filhos legítimos. A Constituição de 1946 manteve a indissolubilidade do casamento, mas estendeu o reconhecimento ao filho adulterino, depois de cessada a sociedade conjugal. A Constituição de 1967, seguida da Emenda Constitucional 1, de 1969, suprimiu o reconhecimento de filhos ilegítimos, fixou em 12 anos a idade mínima para o trabalho e instituiu o ensino obrigatório e gratuito, em estabelecimentos oficiais, dos 7 aos 14 de idade .

Todas as Constituições, salvo a Carta de 1891, instituíram a obrigatoriedade de assistência à maternidade, à infância e à adolescência e sobre a educação de excepcionais.

O Código Civil de 1916, ao dispor sobre filhos naturais e adotivos, deu ênfase para a questão hereditária. A adoção era um ato consensual, de natureza contratual. Era marcante a posição de inferioridade do filho adotivo diante do filho legítimo; a lei cumpria a função de impedir ou dificultar a adoção por quem, de acordo com as presunções da época, apresentasse potencial de conceber filhos de sangue.

A Lei 4242, de 5 de janeiro de 1921, dispunha sobre a lei orçamentária desse ano e, como disposição final, autorizava o Poder Executivo a organizar a assistência e proteção à infância abandonada e delinqüente. Na seqüência, o Decreto 16272, de 20 de dezembro de 1923, no seu art. 24, $\$ 2^{\circ}$., introduziu forma de colocação em família substituta animada do propósito de combater o perigo que representava o adolescente pobre. Se o menor fosse abandonado, pervertido ou estivesse em perigo de o ser, podia ser internado em asilo ou casa de educação, ou ainda confiado a pessoa idônea.

O Código de Menores de 1927 (Decreto 17943, de 12 de outubro de 1927, conhecido como Código Mello Mattos), restringiu seu alcance aos menores abandonados e delinqüentes, não a todas as crianças, dando início à doutrina da situação irregular no Brasil. Modificou o instituto do pátrio-poder, aproximando-o de um pátrio-dever, uma vez que o Estado poderia intervir na relação pai/filho, ou mesmo substituir a autoridade paterna, caso este não tivesse condições ou se recusasse a educar o filho; no entanto nada dispôs sobre qualquer forma de adoção.

A Lei 3133, de 18 de maio de 1957, denominado Estatuto da Adoção, modificou o Código Civil de 1916. Disciplinou mais amiúde a matéria, reduzindo de 50 para 30 anos a idade do adotante e para 16 anos a diferença etária entre adotante e adotado. Exigiu que o adotante fosse casado há no mínimo cinco anos. Dispôs sobre consentimento, 
direito ao nome, proibição de sucessão hereditária e a dissolução do vínculo de adoção. Alterou a redação do art. 377 do Código Civil, que originalmente mantinha os direitos sucessórios do adotado em caso de superveniência de filhos, para excluí-los (a redação "quando o adotante tiver filhos legítimos, legitimados ou reconhecidos, a relação de adoção não envolve a sucessão hereditária").

A Lei 4655, de 2 de junho de 1955, introduziu a legitimação adotiva, constituída por sentença judicial, que conviveu com a adoção simples do Código Civil.

O segundo Código de Menores (Lei 6697, de 10 de outubro de 1979), instrumento da Política Nacional do Bem-Estar do Menor, seguiu a doutrina da situação irregular, agora mais abrangente, porque aplicável não apenas ao menor abandonado e delinqüente, mas, de forma mais ampla, ao menor em situação de patologia social ${ }^{31}$. Revogou a legitimação adotiva e, mantendo a adoção simples (arts. 27 e 28), introduziu a adoção plena (arts. 29 a 37), certamente um avanço, porém restringindo-a ao menor em situação irregular. Além disso, criou a figura da delegação de pátrio-poder, semelhante à guarda, que era conferida a pessoa física e semelhante a colocação em internato.

Segundo A. CHAVES, três espécies de adoção conviviam: a adoção do Código Civil e as duas adoções do Código de Menores, a simples e a plena.

De todo modo, a regra geral, do Código Civil, não protegia suficientemente crianças e adolescentes contra adoções inconvenientes. Em 1981, Alyrio CAVALIERI encaminhou à Associação Brasileira de Juízes de Menores um anteprojeto para alterava o Código Civil, a fim de que qualquer adoção de menor de 16 anos fosse ao menos homologada por um juiz de direito; esse anteprojeto, porém, não teve sucesso.

A Constituição Federal de 1988 mudou radicalmente esse panorama. Era a época em que se assistia ao fenômeno da constitucionalização do direito civil, isto é, em que se reconhecia a supremacia axiológica da Constituição, cujos princípios não apenas fundamentam a interpretação do direito privado, mas acabam por dividir o texto com matéria antes disciplinada por lei complementar ou ordinária. A chamada Constituição Cidadã enunciou os seguintes princípios, entre outros: a dignidade da pessoa humana, o direito à convivência familiar, a paridade entre os filhos naturais ou adotivos, proibida qualquer designação discriminatória, a proteção integral da criança e do adolescente, a prioridade no atendimento.

\footnotetext{
${ }^{31}$ A. CAVALIERI, Direito do menor - 1000 perguntas, Rio de Janeiro, Rio, 1983.
} 
Por conseguinte, toda adoção concretizada no Brasil a partir de 1988 produziu o efeito de integrar plenamente o adotado na família adotiva.

A par do fenômeno da constitucionalização, G. TEPEDINO aponta a mudança radical por que passa o Direito Civil, que, da tradição de maior estabilidade do direito codificado, hoje assiste à "frenética" produção de leis especiais. É que o legislador, no afã de atender às diversas demandas setoriais, não faz cerimônia em comprometer a estabilidade das normas e acaba por subtrair do Código Civil setores inteiros da atividade privada, disciplinando-os integralmente. Surgem os Estatutos, "universos legislativos" que se apresentam radicalmente diversos das legislações excepcional e especial de outrora. ${ }^{32}$

Nesse contexto, surgiu o Estatuto da Criança e do Adolescente, Lei 8069, de 13 de julho de 1990, universo legislativo em torno da doutrina da proteção integral. Explicitou a regra de que a proteção especial do Estado é devida a toda e qualquer criança ou adolescente em virtude da condição peculiar de pessoa em desenvolvimento - não mais a situação irregular - e disciplinou especificamente sua adoção, seguindo as regras decorrentes de convenções e tratados internacionais. A adoção só pode ser plena e exige procedimento judicial; o critério a orientar a concessão das adoções é o melhor interesse da criança.

A evolução legislativa mostra que a criança e o adolescente, inicialmente objeto do pátrio-poder, tornaram-se ao longo do tempo sujeito de direitos, e que suas necessidades específicas, como a colocação em família substituta, foram aos poucos recebendo mais visibilidade e tratamento específico.

CAIO MÁRIO considera o ECA o resultado da evolução de um sistema normativo que sempre se contentou com a pacificação dos conflitos, mas que agora edita leis imbuídas de direitos fundamentais, que os profissionais do direito deveriam assumir com a "função promocional" apregoada por N. BOBBIO desde a década de 70. ${ }^{33}$ ".

O Código Civil de 2002, a despeito de apresentar inovações modestas em relação à adoção estatutária, reproduzindo a quase totalidade das disposições do ECA, pretendeu também regrar indistintamente as adoções de adultos e de memores de idade. Não há divergência em questões de fundo, ficando mantido o princípio da priorização do interesse da criança. Seu art. 1621 faz pressupor que o consentimento para adotar é a regra, mas será dispensado "em relação à criança ou adolescente cujos pais sejam desconhecidos

\footnotetext{
${ }^{32}$ Temas de Direito Civil, $2^{\mathrm{a}}$. ed., Renovar, 2001, p. 8.

${ }^{33}$ C. M. DA SILVA PEREIRA, Instituições de direito civil, vol. III, Forense, $11^{\mathrm{a}}$. Ed., Rio, 2003, XV.
} 
ou tenham sido destituídos do poder familiar" $\left(\S 1^{\circ}\right)$. A partir do Código Civil, não cabe mais adjetivar as adoções.

Eventual divergência o ECA e o Código Civil (como, por exemplo, na questão do ingresso da sentença concessiva da adoção no registro civil, se suscetível de averbação, como no Código Civil, ou se dependente de cancelamento e abertura de novo assento, como prevê o ECA) autoriza o manejo do princípio da especialidade. Sobre o assunto, S. CHINELATO oferece uma orientação imprecisa (prevalência do ECA por ser lei nova), mas sugere um interessante "diálogo das fontes", a partir de citação de Erik Jayme, para que se apliquem "de modo simultâneo, coerente e coordenado as várias e dispersas fontes legislativas convergentes" $" 34$.

Em comentário sobre o Estatuto, O. CORREA aludiu a 'barateamento do instituto" da adoção, referindo-se à ampliação da capacidade para adotar e da possibilidade de adoção (rebaixamento do critério etário, adoção por concubinos e por pessoa solteira); não deixou de enxergar, porém, a inequívoca vantagem : "A única segurança que se pode ter é a de que, sujeita a processo judicial (como, aliás, previsto, detidamente, no Estatuto da Criança e do Adolescente), o Juiz examine, com equanimidade, as condições nas quais se dará a adoção, para deferi-la, ou não" 35 .

O Projeto de Lei 1756/03, que dispõe sobre a Lei Nacional de Adoção, foi apresentado pelo deputado catarinense João Matos e está em fase de discussão.

\footnotetext{
${ }^{34}$ Comentários ao Código Civil, v. 18, Saraiva, 2004, p. 167.

${ }^{35}$ Breve nota sobre a adoção no Código Civil, in "Aspectos Controvertidos do Novo Código Civil”, A. ALVIM e outros, RT, 2003, p. 444.
} 


\section{CAPÍTULO II - PODER FAMILIAR E CONSENTIMENTO PARA COLOCAÇÃO EM FAMÍLIA SUBSTITUTA}

\section{Poder Familiar como Direito da Personalidade}

\subsection{Poder Familiar}

Diz-se se do poder familiar, outrora pátrio poder, que é personalíssimo e irrenunciável. É a tradição de nosso direito conceituá-lo assim.

A mudança na terminologia, que visou somente a extirpar o colorido patriarcalista, isto é, centrado na figura masculina - com isso adequando-se às disposições da Constituição Federal de 1988, à nova redação do artigo 381 do Código Civil de 1916 e ao artigo 21 do Estatuto da Criança e do Adolescente, de que o pátrio poder seria exercido em igualdade de condições por ambos os cônjuges -, não atendeu à moderna concepção do instituto, que nele vê essencialmente um poder-dever a ser exercido a benefício do menor.

Diversos doutrinadores brasileiros contemporâneos, como G. STRENGER ${ }^{36}$, defendem o emprego da expressão "autoridade parental", como no Código Civil francês e no direito norte-americano, porque a consideram mais abrangente do caráter protetor e tutelar, ínsito à relação paterno-filial.

Sobre o caráter irrenunciável do poder familiar, parece have $\mathrm{r}$ consenso.

SILVIO RODRIGUES afirma que o pátrio-poder é irrenunciável porque a lei impôs deveres aos pais, com a finalidade de proteger os filhos, circunstância que "realça o caráter de munus público do pátrio poder"37.

No mesmo sentido, PONTES DE MIRANDA: "Nada obsta a que o pai, ou mãe, que tem o pátrio poder, contrate com o outro (mãe, ou pai) a educação do filho. A renúncia do pátrio poder é nula; nula é a renúncia do próprio exercício dele, ou de algum de seus elementos. Não, porém, o contrato para que alguém eduque o filho. Em vez de colégio, pode ser o outro cônjuge. Se não no merece, o abuso é do titular do pátrio poder e expõe-se ele às medidas dos arts. 394 e 395.". 38.

A afirmada irrenunciabilidade, porém, colide com a existência, no ordenamento jurídico brasileiro, da figura do consentimento para colocação em família

\footnotetext{
${ }^{36}$ Guarda de filhos, São Paulo, LTr, 1998, p. 44 e ss.

${ }^{37}$ S. RODRIGUES, Direito civil, São Paulo, Saraiva, 17 a . ed., p. 358.

38 Tratado de Direito Privado - t. 9, atualizado por V. RODRIGUES ALVES, Campinas, Bookseller. 2000, p. $148 / 157$.
} 
substituta, que, esvaziando totalmente o conteúdo do poder familiar (e ainda para constituir outra situação de direito irrevogável, como o é a adoção), é instituto que em tudo se assemelha a renúncia, cessão ou transferência. Esse assunto será discutido mais adiante.

\subsection{Poder familiar e entrega de Filhos}

Não existe uma distinção rígida entre direitos fundamentais, direitos da personalidade e direitos humanos no Brasil, senão a maior identificação dos primeiros com as outrora denominadas "qiberdades públicas". Os direitos fundamentais e os direitos da personalidade, se não são a mesma coisa, ao menos conhecem intersecções, uma vez que os direitos da personalidade não raro se afiguram especialmente relevantes para a preservação da dignidade humana, como os direitos à integridade corporal, à liberdade e à honra.

Para qualificar tanto direitos humanos quanto direitos da personalidade, o critério maior é a dignidade humana, que, na definição de M. GARCIA, apresenta como conteúdo "a exigência enunciada por Kant como segunda fórmula do imperativo categórico: Age de tal forma que trates a humanidade, tanto na tua pessoa como na pessoa de qualquer outro, sempre também como um fim e nunca unicamente como um meio"39.

V. RAO mostra que os direitos da personalidade incorporam o caráter fundamental no ordenamento: 'Na verdade, as declarações desses poderes essenciais da personalidade reúnem e realizam todos os elementos constitutivos dos direitos subjetivos, tais os da titularidade, exercício e oponibilidade a terceiros, sob a proteção que as respectivas normas atributivas, constitucionais ou legais, lhes conferem; são reconhecidos e assegurados pelo direito objetivo e, ao mesmo tempo, atuam como direitos fundamentais, ou básicos de todo sistema jurídico. ${ }^{40,}$

Os direitos da personalidade, segundo R. LIMONGI FRANÇA, são "ăs faculdades jurídicas cujo objeto são os diversos aspectos da própria pessoa do sujeito, bem assim as suas emanações e prolongamentos" ${ }^{41}$.

\footnotetext{
${ }^{39}$ M. GARCIA, Limites da ciência, RT, 2004, p. 197.

${ }^{40}$ O direito e a vida dos direitos, $2^{\mathrm{a}}$. ed., São Paulo, Resenha Universitária, 1978, p.125.

${ }^{41}$ Manual de direito civil, v.1, 4ª . ed., RT, 1980, p. 403.
} 
A definição de D. GOGLIANO introduz a idéia de que tais atributos atuam como fundamento natural da existência e liberdade: "Direitos da personalidade são os direitos subjetivos particulares, que consistem na prerrogativas concedidas a uma pessoa pelo sistema jurídico e assegurada pelos meios de direito, para fruir e dispor, como senhor, dos atributos essenciais da sua própria personalidade, de seus aspectos, emanações e prolongamentos, como fundamento natural da existência e liberdade, pela necessidade da preservação e resguardo da integridade física, psíquica, moral $e$ intelectual do ser humano, no seu desenvolvimento, ${ }^{, 42}$.

Estabelecidos esses requisitos, constata-se que o direito ao exercício do poder familiar atende-os a todos, e ainda constitui um fundamento natural da existência, uma vez que o nascimento de um filho provoca intensa mobilização das forças morais e psíquicas do ser humano.

A. CHAVES, ao discorrer sobre a questão do consentimento, cita julgado cuja ementa prescreve que "inadmissível que o direito dos pais adotivos, derivando de uma relação contratual, pudesse preponderar sobre o direito da mãe legítima, que é de Direito Natural" (RT 325/260). A associação com o Direito Natural só faz reforçar o argumento em prol do direito da personalidade.

Segundo o art. 11 do Código Civil, “com exceção dos casos previstos em lei, os direitos da personalidade são intransmissíveis, não podendo seu exercício sofrer limitação voluntária". Em princípio, o direito a exercer o poder familiar e à posse dos filhos assemelha-se ao direito à integridade corporal, ou seja, o direito às partes do próprio corpo.

A autorização legal para dispor desse direito encontra-se no art. $45, \S 2^{\circ}$., do ECA e no art. 1621 do Código Civil, que prevêem o consentimento para adoção; disposições congêneres integram as legislações estrangeiras modernas (Estados Unidos da América, França, Inglaterra, Itália, Alemanha).

Nesse passo, a Constituição Federal de 1988 erigiu a dignidade da pessoa humana em valor primordial para a vida dos direitos, aí incluídas a criação, interpretação e aplicação das leis; essa assertiva, que a princípio parece lugar-comum, implica conseqüência menos óbvia: é preciso fixar parâmetros protetivos para garantir o "mínimo ético irredutível" no tratamento do pessoa humana.

\footnotetext{
42 Direitos da Personalidade, dissertação de Mestrado apresentada na Universidade de São Paulo, 1982, p. 404.
} 
Exemplo de norma imbuída da função protetiva da dignidade da pessoa humana encontra-se no art. 23 do ECA, que impõe que "a falta ou carência de recursos materiais não constitui motivo suficiente para a perda ou suspensão do pátrio poder". Com efeito, a idéia de separar apartar os filhos de alguém pelo só fato de ser pobre representa, nos dias de hoje, intolerável discriminação por condição social.

No entanto é força convir que não existe perspectiva de melhora, ao menos no curto prazo, para a diminuição da pobreza e do deficit educacional de boa parte da população brasileira. É uma realidade incontestável: a crescente complexidade do modo de produção capitalista, a dispersão de capitais e de forças de trabalho, a escalada tecnológica que torna descartável o trabalhador, tudo isso aponta para a certeza do aumento da miséria. Pode-se dizer, sem medo de errar, que até os países ricos não estão a salvo de grandes convulsões.

Para F. PIOVESAN, a situação é tanto mais preocupante em virtude dos aos fenômenos da "etnização" e da "feminização" da pobreza, este particularmente visível no marcado aumento das famílias monoparentais chefiadas por mulheres ${ }^{43}$.

São as mulheres, inequivocamente, as vítimas preferenciais da exclusão ${ }^{44}$, e o Poder Público ainda é muito tímido na implantação das políticas públicas previstas no art. 208 do ECA, assistenciais e educacionais, em extensão suficiente para prevenir o abandono. Apenas a título de exemplo, o déficit de vagas em creches da rede pública constitui, na maioria dos municípios, problema social de contornos dramáticos.

Não é possível esquecer o abandono social e emocional a que relegados a mãe ou o pai que entregam seus filhos em adoção.

Nesse contexto, a entrega pode significar, para muitas mulheres, jovens e maduras, a única atitude responsável. Em conseqüência, as decisões respectivas - quando entregar e a quem entregar - podem constituir o único resíduo do exercício de maternidade, que, como visto, é um direito da personalidade.

\footnotetext{
${ }^{43}$ Direitos humanos, p. 6.

${ }^{44}$ E. FAVERO, Rompimento dos vínculos do pátrio poder - condicionantes socieconômicos e familiares, $\mathrm{p}$. 75: "Os sujeitos desta pesquisa são heterogêneos no que se refere às formas como expressam a motivação da desistência ou da imposição da desistência de cuidar do filho. Mas existem regularidades quanto às suas condições de vida: a maior parte é migrante, compõem-se de pessoas solteiras, mulheres sós, com arranjos familiares transitórios ou instáveis, estão sem trabalho ou têm trabalho precário, têm baixa ou nenhuma renda, instalam-se em moradias com poucas condições de habitabilidade ou provisórias, dentre outros". $\mathrm{O}$ emprego do masculino se refere a sujeitos de pesquisa, majoritariamente mulheres. Trata-se da extensa pesquisa que a assistente desenvolveu junto às Varas da Infância e Juventude da Capital de São Paulo. Sua conclusão, porém, é a de que a pobreza não é a única motivação para a entrega de filhos, mas de que vários outros fatores determinam ou influem no surgimento da rejeição. A autora resume o resultado como "falta de condições propícias para o apego".
} 
M. BERENICE DIAS reconhece nesse ato o maior ato de amor possível: "sabendo que não poderá criá-lo, renunciar ao filho, para assegurar-lhe uma vida melhor que a sua, é atitude que só o amor justifica". ${ }^{45}$;

A penúria como motivação exige que o profissional do direito adote, na expressão de F. K. COMPARATO, uma postura de "solidariedade ética" 46 , o que significa inicialmente manter uma atitude respeitosa em relação à mulher que entrega filhos e consente em sua adoção. E em conseqüência reconhecer seu direito de escolha do adotante como um direito materno, ínsito à personalidade e integrante de sua dignidade pessoal, apenas subordinado ao princípio da prevalência do melhor interesse da criança.

É bem verdade que "nem todas as mulheres que entregam seus filhos em adoção o fazem sofrendo intensamente a dor da perda e da impossibilidade de maternálos", consoante o resultado da pesquisa conduzida por L. SANTOS e comentada por S. $\mathrm{KUSANO}^{47}$.

Muitas outras, porém, levaram adiante gestações resultantes de estupro, quando lhes seria possível abortar, em homenagem a convicções íntimas e religiosas e ao desejo de preservar a vida de um semelhante; fizeram-no com paciência e resignação, à espera de entregar o bebê a alguém capaz de amá-lo como filho.

A motivação pode ser mais ou menos nobre, e as decisões mais ou menos dolorosas. Em terreno de intensa subjetividade, não há como deixar de aplicar o princípio jurídico da presunção de boa-fé, mais um motivo para que a escolha materna seja admitida como regra e não como exceção.

\section{Consentimento para Adoção}

Está previsto em praticamente todas as legislações ocidentais (art. 347 do Código Civil francês, art. 297 do Código Civil italiano, art. 1747 do Código Civil alemão). O direito islâmico não admite a alienabilidade do poder parental; contraditoriamente, porém, os muçulmanos instituíram o sistema da "kafala", que se assemelha à delegação do poder familiar do Código de Menores de 1979.

As Regras da Convenção de Nova York sobre os Direitos da Criança (ONU - 1990) prevêem expressamente o consentimento parental:

\footnotetext{
${ }^{45}$ Op. cit., p. 437-438.

${ }^{46}$ Afirmação Histórica dos Direitos Humanos, São Paulo, Saraiva, 1999, p. 45.

${ }^{47}$ Adoção Intuitu Personae, tese de doutorado apresentada à PUC-SP em 2006.
} 
Art. 21-Os Estados-partes que reconhecem ou permitem o sistema de adoção atentarão para o fato de que a consideração primordial seja o interesse maior da criança. Dessa forma, atentarão para que:

a) A adoção da criança seja autorizada apenas pelas autoridades competentes, as quais determinarão, consoante as leis e os procedimentos cabíveis e com base em todas as informações pertinentes e fidedignas, que a adoção é admissível em vista da situação jurídica da criança com relação a seus pais, parentes e representantes legais e que, caso solicitado, as pessoas interessadas tenham dado, com conhecimento de causa, seu consentimento à adoção, com base no assessoramento que possa ser necessário.

A. CHAVES, ao apresentar a "importantíssima questão do consentimento", 48 expressa a idéia de que o consentimento dos pais de sangue é sem dúvida necessário para que o filho possa aceitar de outrem uma paternidade ou maternidade civil que rivaliza com a natural, tanto mais quanto o legislador quer que isto ocorra sem modificar os direitos e os deveres que o adotado tem para com a família natural. Observou que o art. 372 do Código Civil, antes da alteração da Lei 3133, de 8 de maio, de 1957, silenciava a respeito.

O ECA instituiu a consensualidade como regra geral da adoção, ao dispor no caput do art. 45: "A adoção depende do consentimento dos pais ou do representante legal do adotando.

$\$ 1^{\circ}$. O consentimento será dispensado em relação à criança ou adolescentes cujos pais sema desconhecidos ou tenham sido destituídos do pátrio poder.

$\S 2^{\circ}$. Em se tratando de adotando maior de 12 (doze) anos de idade, será também necessário o seu consentimento”.

Já o Código de Menores de 1979 disciplinava o instituto da delegação do pátrio poder, "desejada pelos pais ou responsável", irretratável para delegantes e delegados (arts. 21 a 23). Na crítica ao instituto, P. L. NOGUEIRA recorda: "a nossa lei civil, no entanto, não cuida da delegação do pátrio poder, que é, em princípio, irrenunciável $^{49,}$.

No sistema do Código de Menores, A. CAVALIERI foi perguntado sobre se os pais poderiam dar os filhos em adoção a quem muito bem entendessem.

Sua resposta foi: "O Direito Civil, que trata da adoção, é lei antiga, de época em que não se reconheciam os direitos das crianças, as quais eram como que

\footnotetext{
${ }_{48}^{48}$ A. CHAVES, op. cit., p. 116.

49 op. cit., p.
} 
objetos e não tratadas como sujeitos de Direito. Assim os pais são donos de seus filhos e podem dispor deles como muito bem entendam. Atendidas as exigências do Código Civil quanto à idade, pela simples exibição do registro de nascimento, como se fosse um certificado de propriedade, os pais podem dar seus filhos em adoção até a pessoas sem nenhuma condição física, psíquica, social.”.

Paradoxalmente, o menor em situação irregular gozava de proteção negada ao que tinha pais, pois o juiz poderia intervir.

No que diz respeito ao consentimento para adoção, mesmo os doutrinadores que qualificavam o pátrio poder de irrenunciável viram-se obrigados a aceitar o paradoxo.

S. RODRIGUES, já citado, asseverou: "o consentimento do pai é sempre reclamado, a menos que eles hajam sido destituídos do pátrio poder. Aqui me parece que a medida é de grande alcance, pois essa concordância equivale à renúncia voluntária do pátrio poder. O Código Civil contemplava regra nesse sentido (Cód. Civil, art. 378) ${ }^{50 " . ~}$

W. de BARROS MONTEIRO é peremptório: 'Podem os pais confiar a outrem a guarda ou internar os filhos em pensionatos e estabelecimentos de educação; mas, não se admite abram mão de seus direitos paternos, mediante renúncia. Qualquer convenção nesse sentido torna-se necessariamente írrita e nula. O pátrio poder não corresponde apenas a um direito, mas representa igualmente dever, de que ninguém pode libertar-se por sua exclusiva vontade”. 51

Todavia é certo é que a legislação atual, a saber o artigo 45 do Estatuto da Criança e do Adolescente e o artigo 1621 do Código Civil, prevêem a figura do consentimento dos pais ou representantes legais, criando dificuldade teórica. Examine-se o paradoxo: é um poder-dever irrenunciável, ao mesmo tempo em que admite transferência a terceiro; é múnus público, mas se permite ao exercente que se livre de desempenhá-lo.

Ou seja: em se tratando de adoção, a figura do consentimento, facilmente compreendida na colocação de filho sob guarda, apresenta dificuldade conceitual.

Em primeiro lugar, porque transferir a outrem os encargos que lhe são próprios em virtude da natureza das coisas, eximindo-se da guarda e criação de filhos, parece conduta incompatível com o princípio da paternidade responsável, inscrito na Constituição Federal.

J. A. DA SILVA assevera que no texto constitucional "a paternidade, ou seja, a paternidade consciente, não animalesca, é sugerida. Nela e na dignidade da pessoa

\footnotetext{
${ }^{50}$ S. RODRIGUES, op. cit., p. 348.

${ }^{51}$ W. DE BARROS MONTEIRO, Curso de direito civil, 2 ${ }^{\circ}$. v., São Paulo, Saraiva, $31^{\text {a }}$. ed., 1994.
} 
humana é que se fundamenta o planejamento familiar que a Constituição admite como um direito de livre decisão do casal, de modo que ao Estado só compete, como dever, propiciar recursos educacionais e científicos para o seu exercício. ${ }^{52}$

E em segundo, porque entra em conflito com a irrenunciabilidade característica do poder familiar.

Para R J. ELIAS, a figura do consentimento para colocação em família substituta representa um contra-senso:

"Importante é a diligência tratada no parágrafo único, para se verificar se realmente, os pais concordam com a pretensão dos interessados em ter seu filho sob guarda, tutela ou adoção. Suas declarações, tomadas por termo, representam, na verdade, renúncia ao pátrio poder.

O dispositivo assemelha-se ao que constava no artigo 96, I, do Código de Menores revogado. Discorrendo sobre a questão, em nossa tese de doutorado, $\underline{O}$ direito do menor à família, cit., advertíamos: 'Tal faculdade à disposição, agora, de todos os pais, não é caminho aberto à paternidade irresponsável ${ }^{53}$,

Esse entendimento não é compartilhado por muitos. Para C. PELUSO, por exemplo, o consentimento constitui mero "pressuposto de simplificação procedimental", e não motivo de perda do poder familiar. Quanto à forma, entende que, sendo declaração de vontade, basta que seja veraz, consciente, livre e firme, devendo o juiz tomar as declarações dos pais em audiência especial mas reservada, a ser realizada logo. ${ }^{54}$

Pode-se concluir, assim, que a natureza jurídica do consentimento para adoção é indiscutivelmente de renúncia, porque em tudo se assemelha à renúncia. Mas é uma renúncia especial, qualificada pelo ânimo de beneficiar o filho, ânimo idêntico ao que se encontra na nomeação de tutor. É o que nos parece suficiente para considerá-lo um instituto peculiar do direito de família.

Para melhor analisar o ânimo de beneficiar o filho, é caso de recorrer a estudo conduzido por M. PISANO MOTTA, psicóloga paulista. Cuida-se de pesquisa pioneira junto a mulheres que entregaram seus filhos, descrita na obra "Mães Abandonadas". A certa altura, os resultados contrariam a idéia corrente de que o melhor para a criança é ficar sempre junto da mãe de sangue. Lembrando as situações de

\footnotetext{
${ }^{52}$ J. A. DA SILVA, Curso de direito constitucional positivo, 9a . ed., São Paulo: Malheiros, 1993, p. 721.

${ }^{53}$ Comentários ao estatuto da criança e do adolescente, Saraiva, 2004. p. 47.

${ }^{54}$ Estatuto da criança e do adolescente comentado-Comentários jurídicos e sociais, p. 153.
} 
concepção decorrente de estupro, incesto, prostituição, a psicóloga assevera que muitas mães realmente não têm condições de exercer uma "maternagem" adequada. ${ }^{55}$.

Após a análise de todos os aspectos emocionais envolvidos na entrega e separação, a autora conclui no sentido de que, do mesmo modo que muitas mulheres enviam seus filhos para o Norte e Nordeste para que sejam criados por avós, sem que ninguém possa dizer que essa conduta é de abandono, a entrega de filhos para serem adotados é a conduta que melhor resguarda os interesses destes, abrindo-lhes a perspectiva de serem recebidos e amados como filhos, podendo almejar um futuro mais promissor $^{56}$ (fls. 263).

Como já dito, a aparente indiferença da entrega do filho pode revestir um ato de amor, entendido como forma alternativa do exercício da maternidade a quem não reúne condições materiais ou emocionais suficientes manter consigo o filho.

Não se pode cogitar de conduta assemelhada a exposição ou abandono, pois o consentimento pressupõe a entrega do infante à pessoa eleita, para que ela lhe preste os cuidados necessários, superiores ao que a mãe biológica teria condições de prestar. Aí está a natureza consensual, própria de negócio jurídico.

\footnotetext{
${ }^{55}$ M. A. MOTA PISANO, Mães Abandonadas, São Paulo: Cortez Editora, 2001, p. 33: "O fato de mulheres entregarem o filho que conceberam em adoção cria problemas de várias ordens, sejam éticas, institucionais, socioculturais. Conduz também ao questionamento que estas entregas produzem nas teorias a respeito da relação mãe-filho, nos levando a tentar encaixar esta atitude da mãe que entrega em quadros psicopatológicos".

56 M. A. MOTA PISANO, op. cit., p. 263: A. nosso ver, a idéia socialmente arraigada e confirmada pelos dados por nós encontrados de que a criança estará sempre melhor com a mãe biológica deve ser seriamente questionada se de fato o que desejamos é atender aos melhores interesses da criança.

Ainda partimos de um a priori que não se confirma na prática e que tem gerado problemas sociais de abandono de crianças, de maus-tratos e abuso de toda ordem por parte de mães que de fato não querem e/ou não podem maternar seus filhos adequadamente. Consideramos importante nos questionar: será possível que uma criança fruto de estupro, ou de uma noite passada com um "cliente" ou, ainda, fruto de um incesto?

Há, ainda, outro aspecto que pudemos depreender de nossas entrevistas e que decidimos denominar entregas mascaradas, pois foi significativo que as mulheres que declaravam desejar entregar seu filho em adoção já tivessem outros filhos. Essas mulheres, com certa freqüência, terminavam por não entregar a criança em adoção, procedendo porém à mesma entrega "mascarada" que haviam praticado em relação às outras crianças, ou seja, entregá-las para serem criadas por uma irmã, pela avó da criança, uma vizinha. Sabemos como é freqüente que mulheres migrantes tendam a enviar seus filhos para suas cidades de origem para serem criados por parentes, sem ter notícias dela. Cabe aqui, a nosso ver, um importante questionamento: Nesses casos estaria havendo abandono? Essas mães amam mais a seus filhos do que as que os entregam em adoção? Elas estão atendendo ao interesse da criança?

Evitando vislumbrar estas realidades, ficamos felizes quando a mãe sai da maternidade com seu pequeno filho nos braços e sentimo-nos recompensados por defender a criança e seus interesses, sem nos darmos conta que, assim como a mulher, estamos cegos para a realidade de que talvez numa família adotiva aquela criança seria bem-vinda e poderia vislumbrar um futuro mais promissor".
} 
Ao pragmatismo do legislador, que instituiu a renúncia do poder familiar descrito como irrenunciável, somam-se outras manifestações do Poder Público no sentido do valor social do consentimento.

Nesse passo, políticas públicas existem que acabam por estimular a entrega de filhos. No Estado de Santa Catarina iniciou-se há alguns anos a campanha "Faça Legal", concitando as mães que desejam entregar seus filhos a fazê-lo à autoridade judiciária e não a particulares. São políticas que, ao menos aparentemente, contradizem o princípio constitucional da paternidade responsável. É a admissão da falência em promover condições para o adequado planejamento familiar, bem como ações eficazes de prevenção do abandono.

Anote-se, por fim, que a única medida legal de repressão à entrega de filhos está prevista no artigo 238 do Estatuto da Criança e do Adolescente, quando se tratar de entrega animada do propósito obtenção de vantagem material. Esse dispositivo está em consonância com o estado atual da consciência jurídica, que não tolera o comércio de seres humanos.

À guisa de curiosidade, registro que o aparente consenso no sentido do repúdio da mercantilização das adoções talvez não se mantenha. A reportagem de capa da edição de 16 de novembro de 2005 da Revista Veja, reproduz pensamento do jurista Richard POSNER, Juiz Federal norte-americano. Sua tese é a aplicabilidade pensamento econômico nas decisões jurídicas, inclusive em tópicos controversos como aborto e casamento, idéia compartilhada por Stephen LEVITT, economista e Professor da Universidade de Chicago, autor de "Freakonomics", recente best-seller mundial. Os autores da reportagem ressaltam a circunstância de que tanto POSNER quanto LEVITT são pais adotivos e concordam que, diante da realidade de um mercado clandestino da adoção, o mais racional seria aprovar leis que legitimassem o ato de pagar por uma criança. $^{57}$

A questão da paga já era considerada por F. DOLTO, segunda figura do freudismo francês, ao lado de J. LACAN, a quem superou em termos de popularidade. Em

\footnotetext{
57 Segundo a reportagem de J. TEIXEIRA e M. MARTHE, "Um bom exemplo é a política de adoção: as pessoas que querem adotar uma criança são proibidas por lei de pagar à mãe biológica que deseja entregar seu filho para adoção. Essa é uma medida de controle de preços. Claro que muita agente acaba pagando por uma criança, por baixo do pano, para acelerar o processo. Mais isso inibe o custo da transação e inibe o processo de adoção em prejuízo dos futuros pais e bebês sem lar. Do ponto de vista econômico, o controle de preços é sempre ineficiente. Posner e Levitt são ambos pais de crianças adotadas. Ambos concordam que o mais racional seria deixar outras veleidades de lado e fazer passar leis que legitimem o ato de pagar por uma criança." (edição 1931/2005).
} 
Sexualidade feminina, publicada em 1982, ela apresentou, como alternativa ao aborto, uma criação sua: uma espécie de banco de natalidade, que receberia contribuições pecuniárias regulares, ao longo de três anos, de pessoas interessadas em adotar, como sacrifício a desempenhar em nome do filho desejado. As contribuições reverteriam para a mãe biológica. A adequação para o exercício do papel parental a cargo seria avaliada, em conjunto com as contribuições, durante todo esse tempo. ${ }^{58}$

\subsection{Natureza Jurídica}

Em se tratando de consentimento puro e simples, não dirigido a determinada pessoal, está-se diante de uma declaração unilateral de vontade, que, em nosso direito positivo, somente tem disciplinadas duas modalidades: gestão de negócios e promessa de recompensa.

A intervenção do Estado é obrigatória por força do "caput" do art. 47 do ECA ("O vínculo da adoção constitui-se por sentença judicial, que será inscrita no registro civil mediante mandado do qual não se fornecerá certidão"e do Código Civil, rompe, mesmo nas adoções intuitu personae, o que poderia ter aparência de contrato") e do art. 1623 do Código Civil (“A adoção obedecerá a processo judicial, observados os requisitos estabelecidos neste Código").

O ECA estatui que a adoção depende do consentimento dos pais ou do representante legal do adotado (art. 45, caput). O Código Civil prevê o consentimento para adoção no art. 1624, que o dispensa em caso de menor exposto ou cujos pais sejam desconhecidos ou hajam sido destituídos do poder familiar. A contrario sensu, o consentimento é a regra geral.

\footnotetext{
58 "Proponho alguma coisa inteiramente distinta. Os pais que quisessem adotar teriam de pagar, durantes três anos, uma quantia correspondente ao sustento anual de uma mulher grávida; digo anual porquanto uma mulher que assume a gravidez de uma criança também precisa recuperar-se depois de certas gestações difíceis, e, como sabemos, certos tipos de gravidez obrigam a gestante a interromper o seu trabalho durante a gestação para levar o bebê até o nascimento. Essas quantias, pagas pelos pais desejosos de adotar, seriam recebidas por esse mesmo banco da natalidade, uma vez por ano. Por ocasião desse pagamento, os futuros pais adotivos teriam uma entrevista com um psicólogo que estudaria com eles as suas motivações para adotar, quer elas já sejam ou não pais filhos legítimos ou adotados. Essas entrevistas teriam por objetivo leválos a considerar o acolhimento esperado por parte de uma criança como devendo ser não somente o da mãe e do pai, mas também o da fratria e dos parentes laterais, tios e tias futuros, avós (quando existem), da criança que eles ainda não conhecem e que desejam.”
} 
Prestado ao juiz, o consentimento pode ou não ter em vista pessoa certa. Se é consentimento puro e simples, não há dificuldade em conceituá-lo como ato jurídico de autorização.

Se há um recipiente determinado, como na adoção intuitu personae, trata-se de um negócio jurídico bilateral, porque a pessoa escolhida assume também uma obrigação: cuidar bem do infante, como o faria a um filho de sangue.

Previsto no art. 45 do Estatuto, o consentimento se assemelha a renúncia, mas não o é, pois a tradição do nosso direito é de conceituar o poder familiar como irrenunciável. Não é abandono, pois a colocação em família substituta se presume benéfica ao menor, como forma de poupá-lo de privações morais e materiais. Não equivale à destituição do poder familiar, porque não se trata de sanção, muito embora os efeitos sejam os mesmos, isto é, o de tornar determinada criança disponível para a adoção. Não é ato ilícito, porque, como visto, a lei o prevê como "regra geral".

Concluímos, assim, que se deva conceituá-lo como instituto sui generis, próprio do direito de família.

\subsection{Requisitos}

São seus requisitos, como na generalidade dos negócios jurídicos, a capacidade do agente, o objeto lícito, possível, determinado ou determinável, e a forma prevista ou não vedada por lei (art. 104 do CC).

No que concerne ao agente, em geral é a mãe da criança quem presta o consentimento, fruto de decisão solitária. Não há vontade do pai a considerar, porque o pai biológico não reconheceu a criança, não tendo sequer acompanhado a gestação. Se é casada a mãe biológica, no mais das vezes o filho em questão provém de relacionamento adulterino e foi registrado como sendo de pai desconhecido.

Situações raras há, em a mãe morreu no parto ou não é encontrada; costumam substituí-la a avó ou alguma tia materna da criança.

Cremos que não se deva convocar ou consultar o pai biológico que não reconheceu a paternidade. Se a criança nasceu sem sua assistência e foi entregue a terceiros sem que disso ficasse ele ciente, está manifesto o desinteresse, a indiferença em acompanhar a gravidez e nascimento, que constituem quebra dos deveres ínsitos à paternidade. 
Mantém-se, assim, a vetusta orientação de A. CHAVES: "somente será exigido o consentimento do pai que houver reconhecido o filho natura" 59 .

Considerando que o reconhecimento da paternidade só será possível até o registro da sentença de adoção, criar-se a partir daí um ônus para o suposto pai, que é o de demandar judicialmente os adotantes em busca da verdade biológica (confirmação do vínculo), e, em situações excepcionalíssimas, e desde que comprovadas as melhores condições pessoais e as melhores intenções, reclamar o exercício de alguma parcela dos direitos de pai, como o direito de visitas.

Quanto ao objeto, é o filho nascido com vida, a partir do nascimento.

O consentimento deverá ser informado, ou seja, prestado por pessoa ciente das conseqüências e implicações de sua iniciativa.

\subsubsection{Capacidade}

Tradicionalmente considerada atributo da personalidade, a capacidade consiste na aptidão para exercer por si os atos da vida civil.

Para a psiquiatria, a capacidade diz respeito às faculdades cognitivas, ou seja, à aptidão para aprender, e à ausência de doença mental. ${ }^{60}$

As situações de incapacidade estão arroladas nos arts. $3^{\circ}$ a $6^{\circ}$. do Código Civil e se dividem entre incapacidade absoluta ou relativa. A primeira não pode ser suprida, porque a lei presume a imaturidade absoluta (menores de 16 anos) ou completa falta de discernimento (enfermidade ou deficiência mental, ou impossibilidade de exprimir-se).

A incapacidade relativa atinge os maiores de 16 e menores de 18 anos, os ébrios e toxicômanos habituais, os deficientes mentais que apresentem discernimento reduzido e os excepcionais sem desenvolvimento mental completo.

Para C. BEVILACQUA, "é ao desenvolvimento mental que se deve atender, porque a pessoa é chamada a pôr em movimento o mecanismo jurídico, pela ação de sua vontade, e o que cumpre examinar é se essa vontade é manifestação de um espírito, sobre o qual já se operou, de modo apreciável, a adaptação às condições do viver social, se essa vontade é dirigida por uma inteligência, que tem consciência, mais ou menos firme, do

\footnotetext{
${ }^{59}$ Vide op. cit., p. 123

${ }^{60}$ Vide TABORDA, José G.V. e outros - Psiquiatria Forense. Porto Alegre: Artmed, 2004
} 
meio em que vive, e à qual a educação, ainda que rudimentar, já forneceu os meios de perceber o alcance dos próprios atos" $" 61$.

M. H. DINIZ, ao discorrer sobre a capacidade, descreve-a como uma aptidão que depende do discernimento, de critério, juízo, tino, inteligência, ou seja, de aptidão que a pessoa tem de distinguir o lícito do ilícito, o conveniente do prejudicial ${ }^{62}$.

As normas que disciplinam a capacidade e a incapacidade são de ordem pública e portanto insuscetíveis de alteração por vontade das partes.

Todas as situações de incapacidade, absoluta ou relativa, podem acometer a mãe biológica, ou pais biológicos, de criança que se queira entregar em adoção. É muito freqüente, em nosso meio, a gravidez na adolescência. A debilidade ou a doença mental da mãe constituem causa apreciável de institucionalização de crianças. Já o consumo imoderado de bebida alcoólica e o uso de entorpecentes, principalmente de crack, comprometem as capacidades psíquicas de um grande número de jovens, homens e mulheres.

O consentimento da incapaz, em virtude de idade ou desenvolvimento mental incompleto, dependerá necessariamente de representação ou assistência. A redação do artigo 1621 do Código Civil menciona o consentimento dos pais ou dos representantes legais, reconhecendo-se aí o fenômeno da curatela estendida.

É possível que haja dissenso entre a vontade do assistente e da assistida, ou entre representante e representada.

Se a adolescente desejar entregar o filho em adoção e seu representante ou assistente discordar, ou se o avô ou representante legal quiser consentir na adoção de um neto contra a vontade da mãe incapaz, ficará à mostra o conflito de interesses previsto no art. $9^{\circ}$ do Código de Processo Civil, I, como razão para se nomear curador especial.

Não estará afastado, na primeira situação, o suprimento judicial do consentimento do responsável legal. Na segunda hipótese, porém, presume-se que a mãe adolescente, com a maioridade, adquira as condições de sustentar-se e bem assim de criar o filho. Sua discordância deve ser levada em conta; ao menos em princípio, cabe dar-lhe a chance de exercer a maternidade. Em alguns casos, pode justificar o provimento judicial da emancipação. Em outros, a colocação do filho sob guarda de terceiros ou em entidade de abrigo, desde que temporária.

\footnotetext{
${ }^{61}$ Teoria geral do direito civil, p. 84.

${ }^{62}$ Código civil anotado, p. 6.
} 
A incapacidade decorrente de enfermidade ou deficiência mental, se absoluta (art. $3^{\circ}$, II, do Código Civil), não obsta ao consentimento para a adoção, porque o representante legal do incapaz pode prestá-lo em seu lugar. Mas a situação de mera redução do discernimento por deficiência mental ou desenvolvimento mental incompleto, relativa (art. $4^{\circ}$., II e III), não comporta suprimento, exigindo-se a destituição do poder familiar, mediante procedimento contencioso com observância da ampla defesa, como condição prévia para a adoção.

\subsubsection{Puerpério}

Puerpério, palavra com origem no latim "puer parere" (dar à luz uma criança $)^{63}$, corresponde a uma situação fisiológica. Em geral se diz do puerpério que é o período que se estende do fim do parto (que se dá com a dequitação, ou seja, descolamento e expulsão da placenta) até a volta do organismo materno às condições pré-gravídicas. Outras definições indicam como termo final a completa involução do útero. Conquanto alguns médicos limitem o uso da expressão puerpério a seis ou oito dias, "período em que a mulher se conserva no leito" ${ }^{64}$, geralmente se considera o período de 6 a 8 semanas.

Conquanto se trate de um estado normal, em que o organismo da mulher cumpre função para o qual foi preparado biologicamente ${ }^{65}$, atualmente se considera o puerpério como causa de agravo à saúde materna, em seu tríplice aspecto, físico, psíquico e social, de acordo com o conceito da OMS - Organização Mundial de Saúde. Além da exposição a alterações hormonais, traumáticas (como a exaustão, hemorragia, choque obstétrico) e infecciosas durante ou depois do parto, não há dúvida de que o nascimento de um filho repercute fortemente na esfera psíquica da mulher.

A regra é a normalidade do puerpério, ou seja, a importância mínima do agravo à saúde considerado, tanto assim que o Manual Merck de Medicina, compêndio básico de consulta dos estudantes norte-americanos de Medicina e do mundo todo, refere o puerpério como o período de seis semanas que se segue ao parto, com manifestações numerosas e variáveis, "que não devem ser confundidas com condições mais sérias". A única ressalva é a seguinte:

\footnotetext{
63 O Dicionário Houaiss remete à origem latina "puerperium”, equivalente a parto.

${ }^{64}$ A. ALMEIDA JUNIOR e J. B. O. E COSTA JUNIOR, Lições de Medicina Legal, p. 381.

${ }^{65}$ H.V. DE CARVALHO e outros, Compêndio de medicina legal, p. 325.
} 
A depressão pós-parto ("blues") geralmente aparece dentro de $24 \mathrm{~h}$ do parto, está geralmente limitada a 72 h, e é comum. Se a depressão durar mais do que $72 \mathrm{~h}$ ou estiver associada a falta de interesse pela criança, pensamentos suicidas ou homicidas, alucinações ou comportamento psicótico, isso é patológico. A psicose verdadeira é provavelmente emergência da doença mental preexistente em resposta ao estresse físico e psíquico da gravidez e do parto; é necessário psicoterapia. ${ }^{66}$

Em outras palavras, já se sabe que o puerpério atua como gatilho para crises de doenças mentais pré-existentes (como esquizofrenia, transtornos de humor e psicoses histéricas), podendo coincidir com a primeira manifestação destas. Eis o motivo por que a entidade que alguns médico-legais denominavam "psicose puerperal" no passado, de raríssima incidência, descrita como uma "profunda, mas fugacíssima alteração de consciência da puérpera, levando-a a matar o próprio filho" ${ }^{67}$, já não é reconhecida como entidade psiquiátrica particular ${ }^{68}$.

A relevância do puerpério decorre do direito penal brasileiro, que, ao dispor sobre o crime de infanticídio (art. 123 do Código Penal: "matar, sob a influência do estado puerperal, o próprio filho, durante o parto ou logo após. Pena - detenção, de dois a seis anos"), lançou dúvida sobre a integridade mental da mulher puérpera, ou melhor, da mulher acometida pelo estado puerperal - considerado um estado confusional, de perturbação da consciência.

Concordam os doutrinadores que o legislador penal de 1940 adotou o critério fisiopsicológico, ou seja, aliou a uma dirimente de cunho social (a "honoris causa", qual seja, a intenção de ocultar a desonra própria, sob a forma da gravidez indesejada), um fator fisiológico, que é o estado puerperal.

$\mathrm{Na}$ medicina legal, a tendência é não enxergar no estado puerperal nem alienação mental nem semi-alienação, A. Almeida Junior e J.B. Costa Junior explicam, sobre o art. 123 do Código Penal, que são casos em que a mulher, estando mentalmente sã, mas abalada física e emocionalmente, vem a sofrer "um colapso do senso moral, uma liberação de impulsos maldosos,, chegando por isso a matar o próprio filho”, produto de uma concepção indesejada.

É possível afirmar, fazendo coro aos penalistas mais modernos, que o infanticídio se apóia numa ficção jurídica desvinculada do fenômeno real, que é o

\footnotetext{
${ }^{66}$ Manual Merck de medicina: Diagnóstico e tratamento, $16^{\mathrm{a}}$. ed. (trad.), p. 1889.

${ }^{67}$ Assim a referem A. ALMEIDA JUNIOR, p. 383.

${ }^{68}$ Compêndio de medicina legal, p. 326.
} 
puerpério. Fica patente a superfluidade do infanticídio como crime autônomo, pois suas elementares estariam descritas em outras disposições penais: a honoris causa encontraria guarida no relevante valor social ou moral (atualmente previsto como atenuante), e a influência do estado puerperal nas disposições sobre imputabilidade e semi-imputabilidade, de sorte que matar recém-nascido, nas circunstâncias do atual art. 123 do CP, receberia de qualquer modo um tratamento diferenciado e mais brando do que o homicídio comum.

Enquanto não muda a lei penal, porém, deve-se considerar puerpério como um período suspeito, em que a rejeição ao recém-nascido pode estar associada a perturbação psíquica passageira, ou seja, a uma redução do discernimento. É o princípio da coerência do ordenamento jurídico que obriga a esse raciocínio, pois não faz sentido atribuir, ao mesmíssimo fenômeno biológico, atuação sobre o discernimento para fins penais e nenhum efeito para fins civis.

.A capacidade civil é a regra e a incapacidade, exceção. A incapacidade não se presume. No entanto, se alguns estados psicóticos são inescapáveis, outras afecções psíquicas não o são, como estados depressivos, principalmente se acometem pessoa que não se conhecia antes e cujos sintomas o leigo pode não distinguir de meros traços de personalidade.

Por esse motivo, e tendo em vista que o direito penal não reconhece no estado puerperal uma causa de inimputabilidade, mas de mera redução do discernimento, tanto que o fato continua típico, é caso de considerá-lo motivo de suspeita de incapacidade, já que a redução do discernimento está também prevista na legislação civil como causa de incapacidade relativa (art. $4^{\circ}$., II, do Código Civil).

É por isso que, além de tentar obter desde logo um histórico cuidadoso, na primeira audiência - especialmente para identificar a preexistência do propósito de não criar o próprio filho -, recomenda-se que o magistrado, em consideração a eventual incapacidade decorrente do puerpério, que, como visto, é terreno propício para a eclosão de doença mental, nomeie um curador especial à puérpera, de preferência advogado, para acompanhar o ato judicial e assisti-la ao prestar consentimento. E sobretudo que faça encaminhar a mulher, antes ou depois da audiência, a avaliação psicológica, e se necessário, psiquiátrica, para aferir as condições emocionais e psíquicas de manifestar a vontade.

Se a mãe biológica não se mostrar segura, mas triste e chorosa, deve-se avaliar a conveniência da entrega do infante a algum parente, ou mesmo a colocação em abrigo, para que a mãe lhe faça algumas visitas nos dias seguintes e possa melhor refletir 
sobre sua decisão, de modo a amadurecer esse propósito ou desistir, reassumindo os cuidados do filho.

\subsubsection{Objeto}

Parece-nos evidente que o consentimento só é válido se recair sobre a adoção de criança já nascida. A própria Convenção de Haia estabeleceu como requisito de validade das adoções internacionais que "o consentimento da mãe, quando exigido, tenha sido manifestado após o nascimento da criança" (art. $4^{\circ} ., d$ )

\subsubsection{Forma}

O consentimento deve ser expresso, não admitindo forma tácita. A entrega de filho a terceiro certamente rompe os deveres de guarda e companhia, criação e educação previstos no art. 1634 do CC, mas não vale como anuência e assim não se presta a simplificar o procedimento. Numa palavra: se a entrega se fizer sem manifestação de consentimento em juízo, a adoção estará condicionada a prévia destituição do poder familiar.

Os arts. 45 e 47 do ECA e 1623 do Código Civil não aludem a forma judicial para o consentimento, mas tão-somente a vínculo judicial da adoção. Acreditamos, porém, que o consentimento válido depende da forma judicial, ou seja, é aquele pessoalmente prestado ao juiz, respeitadas as solenidades próprias da audiência judicial, dentre as quais a participação do representante do Ministério Público, em sua função curatelar (art. 82, I, do CPC).

A exigência decorre da gravidade do ato, que cerceia um direito da personalidade, que é o exercício do poder familiar, e da necessidade de controle das condições de manifestação de vontade.

Escrituras públicas e escritos particulares sob a forma de declaração, com ou sem reconhecimento de firma, não substituem a declaração prestada em juízo e ostentam valor meramente indiciário: (i) da vontade de não manter consigo o filho; (ii) da incapacidade econômica para criar e educar o filho.

\subsubsection{Procedimento}


A manifestação do consentimento não depende de sentença homologatória, que nada mais é do que uma confirmação oficial, uma chancela.

Como todo ato jurídico, o consentimento tem seus três planos de existência existência propriamente dita, validade e eficácia - subordinados a suas qualidades estruturais, intrínsecas, e não a circunstâncias externas à manifestação de vontade. Em conseqüência, a homologação judicial do consentimento válido seria expletiva e a homologação judicial do consentimento inválido, nula.

Entre a promulgação do Estatuto e o início da vigência do Código Civil, em 17 de janeiro de 2003, muitos juízes viam na bmologação uma vantagem, que era a de fixar o prazo para arrependimento. Assim, a sentença homologatória transitaria em julgado, se não houvesse revogação ou insurgência fundada em outra causa (como vício da vontade), no prazo de 15 dias.

Essa vantagem, porém, tornou-se inócua, com a disciplina instituída no $\S 1^{\circ}$ do art. 1621 do Código Civil.

\subsubsection{Arrependimento}

O arrependimento está previsto $\S 1^{\circ}$ do art. 1621 do Código Civil (“o consentimento previsto no caput é revogável até a publicação da sentença constitutiva da adoção").

A retirada, ou revogação, do consentimento, constitui um direito, fundado no caráter personalíssimo do exercício do poder familiar e no princípio da precedência da família natural (art. 19 da ECA), que torna excepcional qualquer colocação em família substituta.

S. CHINELATO, ao contrário, entende que a revogação precisa ser motivada, descrevendo-se ao juiz as razões de querer o filho de volta (novos planos, mudança de fortuna) ${ }^{69}$; acreditamos que a regra é a mantença dos filhos junto aos pais, sem embargo das dificuldades materiais (art. 23 do ECA), e que a entrega a terceiros constitui a dolorosa exceção.

Conquanto deva ser automaticamente acolhido, desde que manifestado no prazo de lei (que provavelmente coincide com o puerpério), o arrependimento faz presumir instabilidade potencialmente danosa. É o que basta para que o magistrado tome a cautela

\footnotetext{
${ }^{69}$ Comentários ao código civil, v. 18, Saraiva, 2004, p. 1622.
} 
de ordenar o estudo psicossocial do caso, em acompanhamento. Caso necessário, deverá aplicar as medidas protetivas previstas no art. 101 do Estatuto, até mesmo a colocação da criança em entidade de abrigo - para estadia provisória, enquanto a mãe biológica faz visitas e procura estruturar-se para recebê-lo. Só importa, no caso, que ela expressou o desejo de criá-la. Apenas não se pode colocar a criança em família substituta, mesmo sob guarda, porque a providência seria contraditória, incompatível com a necessidade de reaproximação entre mãe e filho.

Com o arrependimento, o infante deixa de ser considerado disponível para adoção e, se já havia sido entregue a terceiros, retorna aos cuidados da mãe biológica, observada a razoabilidade na questão do tempo. É que se pode imaginar a ocorrência de infortúnio ou de doença grave que, mesmo excluindo a preclusão, impeçam a mãe biológica de manifestar seu arrependimento até meses ou anos depois da entrega. Nesse caso, o arrependimento não produzirá efeitos automáticos, devendo-se levar em consideração a nocividade da ruptura do convívio da criança com a nova família.

Quanto ao limite temporal do arrependimento, o Código Civil fixa como termo final a publicação da sentença constitutiva de adoção.

Esse termo, porém, não é o mais adequado. A boa técnica processual recomenda que o termo inicial ( $($ quo) do prazo, e não o termo final (ad quem), recaia sobre a publicação ou a intimação. Além disso, a prática nas Varas Judiciais da Infância e Juventude mostra que não existe um acompanhamento, por parte dos parentes biológicos, dos atos subseqüentes à manifestação de vontade. Não acompanham o resultado dos estudos técnicos, cujo tempo de execução, aliás, é muito variável.

Se a genitora biológica não se fez acompanhar por advogado, é obrigatório intimá-la pessoalmente da publicação da sentença constitutiva de adoção, sob pena de esvaziar-se qualquer garantia, porque a mera publicação em cartório ou na Imprensa (especialmente diante das restrições impostas para proteger a intimidade das pessoas, eventualmente dos adotantes) não serve a dar-lhe ciência da decisão. Eventual insurgência só poderia ser manifestada, assim,a partir da intimação pessoal da sentença.

À míngua de previsão específica, o prazo para recorrer, por força do art. 152 do ECA (aplicação subsidiária das normas gerais previstas na legislação processual pertinente), deve coincidir com o prazo de 15 dias previsto para o procedimento cível de rito ordinário.

Seguindo essa ordem de idéias, constata-se que a previsão do Estatuto não faz sentido: a genitora contaria com o prazo de 15 dias para se insurgir contra a sentença 
concessiva da adoção, mas não poderia usar da mesma oportunidade para expressar o arrependimento, direito incontestável? É o princípio da segurança jurídica, assim, que manda definir como marco final do arrependimento também o trânsito em julgado da sentença constitutiva da adoção. Cuida-se de sugestão de "lege ferenda".

Quanto ao arrependimento tardio, em princípio não produz quaisquer efeitos, pois a adoção é irrevogável e os efeitos da passagem do tempo incluem o risco de sofrimento e de traumas irreparáveis.

Observa-se, por fim, que em se tratando de adoção intuitu personae, o arrependimento ocorre por conta e risco dos adotantes indicados. Se eles receberam a criança diretamente da mãe biológica, e não de órgão público, não podem discutir ou protestar contra eventual retratação do consentimento - especialmente porque não existe têm direito subjetivo a adotar criança prometida -, e muito menos reclamar de volta as expectativas, os sonhos e os investimentos realizados em função da expectativa da entrega. O risco está sempre presente nessas situações e não é um risco suscetível de cálculo: a emoção da maternidade biológica e o encantamento com o bebê podem demover a mulher mais empedernida, o propósito anunciado como mais seguro. Do ponto de vista dos adotantes, a devolução da criança recebida como filho causa um sofrimento terrível, perda devastadora que se equipara à sensação da morte.

É por isso que jamais se deve estimular alguém a optar pela adoção intuitu personae em detrimento dos trâmites regulares, com inscrição no cadastro de interessados e aguardo por criança disponível para ser adotada, procedimento dotado de muito maior segurança. 


\section{CAPÍTULO III -- A ESCOLHA DOS ADOTANTES}

\section{A escolha dos adotantes}

O conceito de escolha é uma das determinantes fundamentais do conceito de liberdade e o exercício do poder familiar corresponde a direito moral da personalidade; daí a relevância da escolha do substituto na criação de um filho que não se vai manter.

Do ponto de vista da mãe biológica, os critérios determinantes da escolha são de duas ordens: laços de amizade, compadrio ou subordinação hierárquica que fizeram nascer a confiança nos indicados; ou, nos casos em que não existe contato pessoal pessoal importante, o apreço por valores culturais e religiosos eventualmente compartilhados, ou a admiração por virtudes pessoais e sociais.

São as situações em que a mãe biológica está decidida a entregar o filho, mas faz questão entregá-lo a uma família católica; ou faz questão de entregá-lo a determinada pessoa, porque a conhece por reputação, ou a admira etc.

Nossa lei civil não contém prescrições como "A mãe biológica indicará o adotante" nem como "Ouvido o Setor Técnico e o Ministério Público, o juiz escolherá o adotante", ou ainda "É defeso à mãe a mãe biológica indicar o adotante".

Fácil perceber que a lei é omissa, pois não proíbe e nem permite expressamente. Estamos diante de questão atinente a completude do ordenamento jurídico, que é completo, segundo $\mathrm{N}$. $\mathrm{BOBBIO}^{70}$, quando jamais se verifica o caso de que a ele não se podem demonstrar pertencentes nem uma certa norma nem a norma contraditória. Especificando melhor, a incompletude consiste no fato de que o sistema não compreende nem a norma que proíbe um certo comportamento nem a norma que o permite”.

Nesses casos, é dever do intérprete acrescentar aquilo que falta. No sistema do CPC, o juiz não pode se escusar de julgar a pretexto de lacuna ou obscuridade da lei. Para remediar a anomia, deverá recorrer à analogia, aos costumes e aos princípios gerais de direito (art. 126 do CPC ).

Recorrendo-se à analogia - que nada mais é do que a interpretação promovida em face de outros dispositivos, que regulam casos idênticos ou semelhantes ao da controvérsia -, o parâmetro mais adequado está mas disposições de nomeação de tutor (arts. 36 e ss. do ECA e no art. 1729 do CC), que conferem a escolha do tutor ao pai e à

\footnotetext{
${ }^{70}$ Teoria do ordenamento jurídico, 10ª . ed., UNB, 1997, p.115.
} 
mãe. A semelhança entre as situações de escolha de adotante e de nomeação de tutor são duas: (i) o pressuposto do afastamento (perda ou suspensão) do poder familiar exercido originariamente pelos pais; (ii) a conseqüente substituição dos pais pelo tutor, que assumem todos os deveres próprios dos primeiros.

Instituição do direito protetivo, a tutela, segundo PONTES DE MIRANDA, "é o poder conferido pela lei, ou segundo princípios seus, à pessoa capaz, para proteger a pessoa e reger os bens dos menores que estão fora do pátrio poder". ${ }^{71}$

No sistema do Código Civil, a nomeação de tutor deve obedecer as prescrições dos pais e admite forma testamentária. Segundo o art. 36 do ECA, "á tutela será deferida, nos termos da lei civil, a pessoa até 21 (vinte e um) anos incompletos" (com a antecipação da maioridade por força do Código Civil de 2002, lê-se essa idade como 18 anos incompletos).

Não apenas o Código Civil é posterior ao Estatuto, como este faz uso da locução "nos termos da lei civil", tudo a dar a entender que a escolha dos pais será respeitada.

É bem verdade que o sistema de 1916 preocupava-se principalmente com o órfão rico, com o propósito de preservar-lhe os bens. O caráter patrimonialista da tutela fazia irrelevante o instituto no cotidiano da Varas da Infância e Juventude, cuja competência para aplicá-la dependia de eventual situação de risco do menor (art.. 148, § ún, $a$ do ECA).. Porém a mudança do art. 16 da Lei 8213/91, Lei dos Benefícios da Previdência Social, mudou radicalmente esse panorama, uma vez que a lei previdenciária passou a reconhecer o status de dependente somente ao menor sob tutela, não mais ao menor sob guarda. Para garantia do amparo previdenciário, muitas destituições do poder familiar tiveram lugar, para deferimento de tutela..

O Código Civil de 2002 arrola, dentre os poderes-deveres dos pais, o de "nomear-lhes tutor por testamento ou documento autêntico, se o outro dos pais não sobreviver, ou o sobrevivo não puder exercer o poder familiar" (art. 1634, IV).

Mais a mais, a tutela insere-se, tanto quanto a adoção consensual, no âmbito dos procedimentos de jurisdição voluntária. J.F. MARQUES esclarece que, salvo nos casos de tutela por ato de última vontade, a intervenção judicial se faz presente desde a nomeação do tutor. Quando a nomeação é testamentária, o juiz intervém em seguida

\footnotetext{
${ }^{71}$ F. C. PONTES DE MIRANDA, op. cit., p. 305.
} 
através de diversos atos de jurisdição voluntária, graciosa a administração dos bens do tutelado, a correção do menor, o arbitramento de gratificação ao tutor etc.

Caso fossem invocados os costumes para sanar a situação de anomia, a dúvida igualmente se resolveria em prol da admissibilidade da escolha dos pais biológicos. É que a tradição jurídica brasileira, forte no caráter contratual da adoção, contentava-se com a exigência do consentimento concordante dos adotantes e dos representantes legais do adotado, se este era menor de idade. Não havia interferência direta dos Poderes Públicos e a vontade dos pais biológicos era acatada sem questionamentos.

Na dicção de CLÓVIS BEVILACQUA, "mais exato e mais compreensível é dizer que o fundamento da força obrigatória do costume está na conformidade reconhecida entre ele e as necessidades sociais que regula" ${ }^{, 72}$.

Pesquisadas as necessidades sociais, constata-se que a iniciativa da mãe biológica na escolha dos adotantes está enraizada em nossa cultura, por causa da influência da figura do "padrinho" na formação do povo, majoritariamente católico, e da desconfiança das instituições oficiais (como a "Roda dos Enjeitados").

É o que basta a dizer consolidado o costume, reconhecendo-se tanto a observação constante da norma jurídica não escrita, como o elemento anímico, outrora designado de "consciência coletiva" ou "a expressão da consciência do povo".

Conclui-se, portanto, no sentido da admissibilidade da escolha do adotante pelos parentes biológicos.

\section{Precedência da família natural}

$\mathrm{O}$ art. 19 do ECA instituiu o princípio da precedência da família natural.

Em se tratando da entrega de recém-nascidos a família substituta, porém, esse princípio não é absoluto. Em nome do melhor interesse da criança, deve-se em princípio respeitar a decisão materna de alijá-lo da família de origem.

As várias situações possíveis recomendam cautela:

A situação patológica, mas que não se pode excluir, é a de filiação incestuosa ou decorrente de estupro, em circunstâncias que a mulher mantém em segredo. Constrangê-la a conviver com o filho indesejado na família estendida não seria

\footnotetext{
${ }^{72}$ Teoria geral do direito civil, $3^{\text {a }}$. ed., Rio, 1980.
} 
humanitário e nem coerente com a tradição do direito brasileiro, que sempre reconheceu a honoris causa (motivação de esconder a desonra) como valor relevante.

Noutras situações, a mãe decidiu entregar seu bebê a casal de sua escolha, mas se interpôs a avó ou alguma tia materna para reclamar para si o infante, com o objetivo de conservá-la na família de origem. Não o desejam como a um filho, apenas querem evitar o que consideram a degradação maior da família ("imagine dar o nosso sangue").

Tal intervenção não pode ser acolhida. Se dissesse respeito a pedido de adoção, ol motivo não seria considerado legítimo (art. 43).

A entrega de um recém-nascido a pessoa estranha faz presumir que a mãe lançou mão do último recurso, justamente porque não encontrou apoio e solidariedade no seio de sua própria família. Se o desejasse, ela teria mais e melhores meios, em comparação com o pessoal dos serviços técnicos judiciários, de procurar avós, tios ou primos com quem deixar o infante.

A falta ou carência de meios materiais não pode justificar, de modo algum, a desconsideração da precedência da família natural, consoante o disposto no art. 23 do ECA. Mas é o elemento afetivo que muitas vezes não se compraz com a alternativa de manter o infante na família de origem estendida: toda pessoa tem o direito de ser recebido e amado como filho; acomodar-se a outra situação, como a de neto, sobrinho ou primo, sem jamais ter sido filho, é certamente menos favorável do ponto de vista psíquico.

A criança “doada”, entregue a terceiro, estará afastada do convívio da mãe de sangue. Provavelmente conhecerá sua condição de adotiva, mas não experimentará o sentimento concreto da rejeição ao encontrá-la ou ouvir falar dela, menos ainda ao vê-la na companhia de outros filhos. A criança recolocada na família estendida contra a vontade da mãe, porém, ficará exposta a esses desconfortos e possíveis constrangimentos.

O Estatuto, ao proibir que os avós e irmãos do menor o adotassem (art. 42, $\S 2^{\circ}$. do ECA), objetivou evitar situações confusas, capazes de trazer sofrimento. A conseqüência é que o infante colocado junto a irmãos ou avós será necessariamente acolhido sob guarda, sem acesso a direitos sucessórios ou previdenciários (art. 16 da Lei $8213 / 91)$.

Em se tratando da família estendida, para além de parentes de segundo grau, conquanto não exista a proibição de adotar, o acolhimento normalmente se faz sob guarda, com a mesma exclusão de direitos sucessórios e previdenciários. Sob o aspecto moral, a possibilidade confusão é a mesma. Está-se rigorosamente diante da mesma ratio legis. 
Por conseguinte, em princípio não atribuímos ao juiz o dever de, uma vez desfeita a indicação intuitu personae, procurar por parentes da mãe biológica que possam acolher a criança.

\section{O Julgamento de Equiidade}

Para ARISTÓTELES ${ }^{73}$, a equidade intervém para julgar não com base na lei, mas com base na justiça que a própria lei deve realizar. O justo e o eqüitativo são a mesma coisa; o eqüitativo é superior, não ao justo em si, mas ao justo formulado em uma lei que, em virtude da sua universalidade, está sujeita ao erro.

Não é a lacuna no ordenamento jurídico brasileiro, decorrente de omissão no ECA e no Código Civil (que, como visto, não proíbem a adoção intuitu personae nem a disciplinam), que autoriza o julgamento de eqüidade. É o aspecto prático, pois a entrega de filhos a pessoas eleitas pelos parentes de sangue em princípio não apresenta antagonismo caracterizável como lide, ensejando procedimento de jurisdição voluntária. Assim, está autorizado o recurso ao juízo eqüitativo, porque o art. 1109 do CPC dispõe que "o juiz decidirá o pedido no prazo de 10 (dez) dias; não é, porém, obrigado a observar critério de legalidade estrita, podendo adotar em cada caso a solução que reputar mais conveniente ou oportuna". Esse dispositivo é aplicável por força do art. 152 do ECA.

A característica mais visível da jurisdição voluntária é a administração pública de interesses privados, em que a espécie de direito material torna necessária a intervenção do juiz para completar ou realizar o negócio jurídico-privado.

J. F. MARQUES adverte para o caráter paradoxal da jurisdição voluntária, que não é nem jurisdição nem voluntária ${ }^{74}$, e acrescenta que a atuação dos juízes e tribunais, cuja necessidade a lei impões, poderiam ser atribuídos a outros órgãos estatais. Ainda assim, confere à jurisdição voluntária, nas questões familiares, papel de sumo relevo, em especial na intromissão obrigatória nos casos de desquite (separação) consensual.

Em sentido contrário, C. DINAMARCO assevera que o CPC não apenas afirma a existência das duas vertentes da jurisdição (contenciosa e voluntária), “como

\footnotetext{
${ }^{73}$ Ética a Nicômaco, EDIPRO, 2002, p. 160.

74 "Tão paradoxal é a jurisdição voluntária, que os fenômenos que ela indica nem são jurisdicionais nem tampouco voluntários. A denominação é empregada assim para designar atos jurídicos de todo diversos daquilo que significam as palavras que a compõem: nos casos de jurisdição voluntária, a intervenção judiciária é obrigatória e imprescindível, e os atos que o juiz pratica nada têm de jurisdicionais" (Jurisdição voluntária, $1^{a}$. ed. revista e atualizada, Millenium, 2000, p.320).
} 
também manda que a segunda delas se exerça segundo os atos, as formas e as garantias inerentes ao processo civil. Há procedimentos a observar, está presente o contraditório, as decisões e sentenças devem ser motivadas, opera o duplo grau de jurisdição etc. - enfim, prevalecem os padrões ditados pela garantia do devido processo legal"75.

Convém reafirmar que o juízo eqüitativo não dispensa a fundamentação das decisões, garantia processual de status constitucional (art. 93, IX da CF). Trata-se de garantia contra o arbítrio e o abuso de autoridade, na medida em que confere ao interessado a real possibilidade de impugnação, inviável se não se conhecessem os motivos do decidido, além de permitir aos julgadores das instâncias revisoras a melhor avaliação das decisões.

É uma garantia indissociável do princípio da legalidade, uma vez que a sentença serve a conferir densidade concreta às palavras vagas e genéricas que a lei emprega.

Segundo C. PERELMAN, o caráter público da jurisdição "impede identificar, pura e simplesmente, o que é justo segundo o direito com o que parece justo a um indivíduo. É raro que uma solução se imponha socialmente de modo unânime, sem que se consiga, de outro lado, no estado atual da legislação, motivá-la de modo coerente"76.

No que diz respeito à adoção, é obrigatório que se dê uma resposta, compreensível e concretamente apoiada na lei ou em dados da realidade, à mãe biológica que não teve sua escolha respeitada, ao casal que teve indeferido seu pedido de inscrição no cadastro, ao casal que não foi admitido a adotar, ao estrangeiro que foi alijado do procedimento etc.

\section{O Rito}

A adoção do Código Civil de 1916 aperfeiçoava-se por simples escritura pública, negócio bilateral entre adotante e adotado, que, se fosse incapaz, era assistido ou representado por seus pais ou responsáveis. Somente a adoção dos menores em situação irregular reclamava, no sistema do Código de 1979, a intervenção judicial, a cargo do Juiz de Menores.

Com o advento do Estatuto e a obrigatoriedade da intervenção judicial, as adoções consensuais passaram a integrar o rol dos procedimentos de jurisdição voluntária,

\footnotetext{
${ }^{75}$ Instituições de direito processual civil, v. I Malheiros, 2001, p. 316.

${ }^{76}$ Lógica jurídica, Martins Fontes, 2000, p. 98.
} 
observando-se que, no âmbito da jurisdição da Infância e Juventude, só existe necessariamente lide (antagonismo, conflito de interesses caracterizado por pretensão resistida) nos casos de perda e suspensão do pátrio poder ou de aplicação de medida sócioeducativa.

Em conseqüência, o rito dos procedimentos é simplificado e informal, como nos denominados pedidos de providência, ou procedimentos verificatórios, destinados a apurar e acompanhar menores em situação de risco.

O juízo eqüitativo, que no mais das vezes se expressa como um juízo de conveniência, não diz respeito apenas ao mérito do pedido apenas, mas às questões procedimentais. J. F. MARQUES explica: "No procedimento voluntário, o que há são formas destinadas a melhor realização da atividade pública-administrativa pelo juiz. Os atos que se sucedem nesse procedimento não se adiam disciplinados com o mesmo formalismo da relação processual pois, aí, a forma não tem aquele caráter indeclinável que se imprime a certos atos processuais" $" 77$.

Aspecto muito importante a considerar é o fato de que, segundo o mesmo autor, "os casos de jurisdição voluntária não se transformam em contenciosos porque haja controvérsia ou recurso" ${ }^{, 78}$. Nesse passo, superveniente desarmonia das partes ou discordância do Ministério Público não transformam a natureza da atividade jurisdicional, definida por sua forma e conteúdo.

Estabelecidas essas premissas, entendemos que o juízo eqüitativo peculiar aos procedimentos de jurisdição voluntária encontra como único limite, na área da Infância e Juventude, a preservação das seguintes garantias processuais, necessárias a proteger os direitos fundamentais da pessoa: 1) o direito a ser cientificado do motivo da instauração do procedimento; 2) o direito a ser ouvido; 3) o direito a manifestar sua livre vontade; 4) o direito a ser informado da possibilidade de constituir advogado ou de recorrer à assistência judiciária gratuita para a defesa de seus interesses.

São garantias processuais compatíveis com a ausência de lide, mas suficientes à satisfação do requisito do devido processo legal; no mais, admite-se maior flexibilidade nos procedimentos, atribuindo-se maior autonomia ao juiz, possibilitando-lhe exercer sua função criativa em grau maior.

Para concretizar as garantias reconhecidas, deve-se providenciar, em todos os casos de suspeita de incapacidade do genitor ou da genitora, ou ainda de manifestação

\footnotetext{
${ }^{77}$ Op. cit., p.228.

${ }^{78}$ Op. cit., p. 229.
} 
de mulher no estado puerperal, mesmo no âmbito dos pedidos de providências, um curador especial ad hoc a seu benefício, de preferência advogado, para que acompanhe a audiência e preste a orientação necessária.

A atuação curatelar para o ato envolve principalmente a fiscalização da fidelidade dos registros, ou seja, a perfeita consonância entre a vontade externada e o que resultado material do termo, para que não haja futura alegação de erro, prejudicial à estabilidade das situações jurídicas e desastrosa em se tratando de colocação de crianças.

Atente-se para que, no âmbito da jurisdição da Infância e Juventude, toda vez que se constatar antagonismo ou disputa caracterizável como lide, mesmo se o procedimento estiver erroneamente registrado como pedido de providências, a marcha processual seguirá o modelo tradicional, instaurando-se o contraditório segundo as prescrições mais rígidas do Código.

Inúmeras práticas judiciárias, de inspiração eqüitativa, vêm se consolidando no cotidiano das Varas da Infância e Juventude, como a oitiva de todos os envolvidos em conjunto, a fim de se observar a harmonia ou o conflito entre eles. Há aí inequívoca vantagem, como aquelas que a acareação proporciona nos processos em geral.

Por fim, a despeito de não constar no ECA expressa menção aos princípios da "celeridade, oralidade, informalidade, simplicidade" (princípios que o legislador mandou aplicar aos Juizados Especiais), são eles os mais condizentes com a urgência ínsita à "absoluta prioridade" instituída no art. $4^{\circ}$., caput, do ECA, mormente no contexto de varas judiciais cumulativas. Além disso, tais princípios constituem tendência inexorável de evolução do sistema processual como um todo, movimento que justificou a autorização legal do registro audiovisual dos atos e a criação, m Estado de São Paulo, de Varas Judiciais Digitais.

\section{Adoção intuitu personae}

Realidade sempre presente, por conta da fragilização dos vínculos conjugais e da ineficiência das políticas públicas de conscientização e prevenção de gestações indesejadas, a entrega de filhos suscita um sem-número de questionamentos no plano jurídico.

Adoção intuitu personae ou adoção consensual é aquela em que os pais biológicos escolhem os adotantes sem prévia intervenção judicial. Efetivada materialmente 
a entrega da criança, somente então se apresentam em juízo, para revestir o negócio jurídico da forma legal.

Existe uma natural desconfiança acerca da capacidade de discernimento da mulher que entrega seu filho em adoção, que se desfaz de um filho, atitude que contraria os deveres jurídicos ínsitos ao poder familiar, em especial os deveres elementares de guarda, educação e sustento. Além disso, a desconfiança recai sobre o vínculo que se estabelece entre pais biológicos e pais adotivos em função da entrega - possivelmente um vínculo de gratidão, capaz de propiciar contatos futuros, de duvidoso benefício para o filho adotivo.

E. GRANATO confirma que os entendimentos e procedimentos não são uniformes nas Varas da Infância e Juventude e esclarece que "o tema não tem sido focalizado pelos estudiosos da adoção, mas é dos mais angustiantes e perturbadores para aqueles que efetivamente trabalham nesse campo e ocorre com uma freqüencia muito superior à que se imagina....”. A possibilidade para o casal escolhido de adotar a criança, conclui, torna-se totalmente "aleatória"79.

A observação é apropriada, na medida em que diversos comentaristas do Estatuto, como R. J. ELIAS, A. MARMITT e V. ISHIDA silenciam sobre o assunto, deixando de reconhecer sua relevância ${ }^{80}$.

Outros comentaristas do Estatuto divergem. Enquanto que o juiz paulista C. E. PACCHI, convidado a comentar o tema adoção na obra coletiva coordenada por M. CURY e outros, expressa que “a adoção intuitu personae é admissível (JTJ 177/14), porém condicionada à prévia avaliação dos pretensos adotantes" ${ }^{\prime 81}$, M. H. DINIZ afirma “...não há adoção intuitu personae, pois o magistrado é quem terá o poder-dever de optar pela família substituta adequada e não os pais ou representantes da criança a ser adotada e muito menos os adotantes." 82.

A exigência legal da formação de cadastro de interessados em adotar em cada Comarca (art. 50 do ECA), com os procedimentos para avaliar e atestar a aptidão para adotar dos candidatos, constitui muitas vezes o argumento único para a recusa da adoção intuitu personae como possibilidade.

A Fundação Orsa editou o "Primeiro Guia de Adoção de Crianças $e$ Adolescentes do Brasil", em que a adoção intuitu personae é identificada como "o pedido

\footnotetext{
${ }^{79}$ Adoção - Doutrina e prática, Juruá, 2003, Curitiba, p. 134.

${ }^{80}$ São as obras já indicadas.

${ }^{81}$ M. CURY et alii (coord.), Estatuto da criança e do adolescente comentado - Comentários jurídicos e sociais, Malheiros, $3^{\mathrm{a}}$. ed., 2000, p. 153.

${ }^{82}$ Vide comentário ao artigo 1625 do Código Civil in "Código Civil Anotado, $10^{\text {a }}$ ed., Saraiva, 2004, p. 1205.
} 
para legalizar uma situação já definida, como se fosse um fato consumado". Consta que "há juízes que têm como diretriz jamais aceitar uma adoção pronta e só considerar os candidatos previamente avaliados e incluídos no cadastro de pretendentes". A opinião do profissional do direito consultado, porém, um Promotor de Justiça de São Paulo (C. GUIMARÃES DOS SANTOS), é a seguinte: "Não vejo qualquer obstáculo legal na aceitação da adoção 'intuito personae', entendida como aquela em que a mãe escolhe a pessoa a quem vai entregar o filho. $O$ argumento contra o 'intuitu personae' funda-se em uma odiosa suposição de delito, esquecendo-se que na adoção a vontade dos pais não pode e não deve ser ignorada. Portanto, a menos que se consiga comprovar adequadamente - o que demanda a existência de indícios sólidos - a ocorrência de comportamento delituoso capaz de comprometer a legitimidade da adoção, não pode haver obstáculo à sua conclusão".

A discussão envolve, em última instância, reconhecer um caráter mais ou menos público na adoção, cuja natureza contratual sempre foi afirmada entre nós, a despeito de tratar-se de procedimento atualmente que só se aperfeiçoa por sentença e que exige assistência do poder público.

A doutrina tende a enxergar, na hipótese das adoções intuitu personae, atividade judicial de jurisdição voluntária, insuficiente ao exercício da função protetiva e tutelar do Estado.

São dois os motivos que nos levam a concluir pela admissibilidade da adoção intuitu personae: (i) a iniciativa da escolha da mãe biológica corresponde em tese ao resíduo possível, diante de circunstâncias adversas, do exercício do poder familiar, que é direito da personalidade; (ii) a prática não está prevista e nem proibida na lei, a analogia e os costumes autorizam sua prática. Mas a admissibilidade está condicionada a efetiva vantagem para a criança. Sempre haverá necessidade de avaliar os critérios que a mãe elegeu para a escolha dos adotantes, a natureza do vínculo que irá se constituir entre eles, além dos requisitos gerais de adequação dos adotantes (aspectos como motivação, estrutura emocional e material, aceitação por parte dos demais integrantes da família). Há critério fundamental a empregar na espécie, que é a prevalência do melhor interesse da criança (tradução da expressão anglo-saxônica "best interest of child").

16. $\mathrm{O}$ art. 50 do ECA 
Dispõe o art. 50 do ECA: "A autoridade judiciária manterá, em dada comarca ou foro regional, um registro de crianças e adolescentes em condições de serem adotados e outro de pessoas interessadas na adoção.

$\$ 1^{o}$ O deferimento da inscrição dar-se-á após prévia consulta aos órgãos técnicos do Juizado, ouvido o Ministério Público.

$\S 2^{\circ}$. Não será deferida a inscrição se o interessado não satisfizer os requisitos legais, ou verificada qualquer das hipóteses previstas no art. 29".

M. BERENICE DIAS aponta uma "exacerbada tendência de sacralizar a lista de preferência e não admitir, em hipótese nenhuma, a adoção por pessoas não inscritas", que considera uma intransigência cega. ${ }^{83}$

Emprestar ao cadastro esse caráter quase sagrado, como se estivéssemos tratando de licitação, constitui séria ruptura com o sistema anterior ao Estatuto, em que a escolha costumava ser informal; o Código de Menores de 1979 não previa avaliações ou instituição de cadastro de interessados em adotar. Parece de outro mundo o comentário do P. NOGUEIRA a seu cotidiano como Juiz de Menores: "quando uma família se apresenta com a maior boa vontade para recolher uma criança abandonada, o seu oferecimento já é, portanto, a melhor das recomendações. Deve o juiz de menores entregar a criança, mediante termo de guarda provisória, sem fazer qualquer sindicância, pois a situação não só requer solução imediata, como a sindicância poderá melindrar que se dispôs espontaneamente a receber o menor ${ }^{84, "}$.

A existência de cadastro de interessados não significa que somente os cadastrados possam adotar. A lei não enuncia essa restrição, e entendimento diverso pressupõe construção interpretativa dissociada da razoabilidade e do sentido finalístico do Estatuto, que é o melhor interesse da criança, fórmula que não se compraz com posturas dogmáticas e juízos de valor apriorísticos.

Se o legislador pretendesse restringir aos cadastrados a possibilidade de adotar, teria erigido o ingresso no cadastro em condição, a par das já existentes (como a diferença etária etc.). Mas não o fez.

Nessa situação, o silêncio do legislador diz muito; autorizado está o emprego das regras de hermenêuticas baseadas na lógica formal. A propósito, C. MAXIMILIANO apresenta justamente o brocardo o "Ubi lex volui dixit, ubi noluit tacuit" (quando a lei quis determinou; sobre o que não quis, guardou silêncio), que ainda desfruta

\footnotetext{
${ }^{83}$ M. DIAS, op. cit, p. 437.

${ }^{84}$ P. L. NOGUEIRA, op. cit, p. 46.
} 
do prestígio, relativamente sólido, das parêmias que sintetizam normas ou processos de hermenêutica, no contexto de obsolescência dos brocardos promovido pelas modernas codificações ${ }^{85}$.

Sobre a questão da exegese, A. SILVEIRA, fortemente influenciado pela teoria de R. SICHES, apresenta sua conclusão: "na aplicação do Direito, não há a uniformidade lógica do raciocínio matemático, e sim a flexibilidade do entendimento razoável do preceito" ${ }^{, 86}$

A razoabilidade, no caso do direito a adotar, está no reconhecimento de que a jurisdição da Infância e Juventude entra em contato com tantas e tão diversas situações, que não seria enfeixar todas as variáveis numa única resposta, e pretender que essa única resposta represente sempre o melhor interesse da criança.

Registre-se, por fim, que o Projeto de Lei 1756/03 não dispõe sobre a questão. No entanto prevê, em seu artigo $8^{\circ}$, que somente será deferida adoção em favor de candidato brasileiro não inscrito no cadastro "quando se tratar do pedido de adoção unilateral, ou formulada por parente próximo, ou com adesão expressa dos genitores, ou quando se tratar de guarda fática, em que o lapso do tempo de convivência comprove a fixação de laços de afinidade e afetividade".

17. Os critérios judiciais

17.1. A qualificação dos adotantes

O art. 29 do ECA prevê: "Não se deferirá colocação em família substituta a pessoa que revele, por qualquer modo, incompatibilidade com a natureza da medida ou não ofereça ambiente familiar adequado"; já o art. 50, caput, prevê, como impedimento à inscrição no cadastro, o não-preenchimento dos requisitos legais.

E o art. 43 do Estatuto dispõe: "A adoção será deferida quando apresentar reais vantagens para o adotando e fundar-se em motivos legítimos".

Requisitos legais são, estritamente, o propósito de constituir família e a diferença etária de 16 (dezesseis) anos entre adotante e adotado, prevista no $\S 3^{\circ}$ do art. 42 do ECA e no art. 1619 do Código Civil. Sobre o propósito de constituir família, mais do que o estrito vínculo de filiação, é o que se extrai das regras contidas no $\S 2^{\circ}$ do art. 42 e

\footnotetext{
${ }^{85}$ Hermenêutica e aplicação do direito, Forense, 1980, p. 243.

${ }^{86}$ Hermenêutica no direito brasileiro, RT, 1968, p. 82.
} 
no $\S 1^{\circ}$. do art. 42 do Estatuto, segundo as quais uma pessoa pode adotar só, independentemente do estado civil; mas só poderá fazê-lo em conjunto com outra se forem casadas ou viverem em união estável, ou em caso de matrimônio ou união estável pretérita, desde que iniciada a convivência com o adotado na constância da sociedade conjugal ou do convívio.

A necessidade de ambiente familiar adequado se traduz em duas ordens de requisitos: os requisitos estritamente subjetivos e o requisito de motivação.

Quanto aos primeiros, exige-se do candidato ou do casal de candidatos a adotante que reúnam as condições materiais suficientes a propiciar um desenvolvimento saudável ao adotado. Não se concebe a condição ideal, porque esta irá variar muito em função de tempo e lugar, mas condições adequadas tendo em vista o nível sócio-econômico do candidato. Entender de outro modo seria alijar desse processo a maior parte da população brasileira, empregando-se critério discriminatório que a Constituição Federal proíbe.

Nesse aspecto, deve-se exigir a estabilidade de ao menos uma fonte de renda, que não obrigatoriamente emprego formal, e moradia em condições dignas. Porém o conceito de dignidade na habitação é bastante variável, de acordo com a classe social do morador, dando azo a elastério na interpretação; no Estado de São Paulo, normalmente não seria possível considerar digna uma residência desprovida de água encanada, saneamento básico e luz elétrica.

Ultrapassada as exigências materiais, os candidatos devem ser avaliados sob o prisma das condições psicológicas, ou condições estruturais da personalidade, de modo a que se conclua que reúnem condições de cuidar de uma criança ou adolescente e construir um vínculo significativo de afeto com ela. É isso, em última instância, que define a assunção do papel parental. Assim, faz-se obrigatório reprovar candidatos que se mostrem excessivamente imaturos, dependentes ou agressivos, tomando-se como paradigma o comportamento médico para a faixa etária e cultural.

Na doutrina italiana, o elemento afetivo apresenta já um duplo perfil: a idoneidade afetiva e o próprio direito ao afeto. L. BARBERA adverte que se pode sustentar, instruir e educar com ou sem afeto, mas que o afeto nas relações entre pais e filhos é coisa fundamental para a realização existencial dos filhos. ${ }^{87}$

\footnotetext{
${ }^{87}$ Vide "L’idoneità affettiva tra interesse del minore e rapporti familiare: spunti sistematici", Quaderni di Diritto Civile, 2004, Giuffré, pp. 190 "Si è visto che l'affetto produce effetti (giuridice), occorre ora sciogliere l'incognita ed accertare quale sia la natura di questo concetto, cominciando com il dimostrare che
} 
Afeto e preparo para a autonomia, é o que se espera dos pais na atualidade. A expectativa contrária - a espécie de pais que os pretendentes à adoção não devem ser não é tão fácil de resumir, podendo-se usar da expressão "pais tóxicos" ("toxic parents"), que a psicoterapeuta Susan FORWARD introduziu e que recebeu imensa atenção ao ser citada por A. GIBBENS. ${ }^{88}$

Tóxicos são os pais que causam reiterado dano à auto-estima dos filhos, seja porque são emocionalmente inadequados ("não ligam" para os filhos), controladores, alcoólatras, agressores verbais e físicos ou abusadores sexuais. Segundo GIBBENS, são tóxicos os pais que obrigam os filhos a "batalhas eternas com as memórias e os personagens de sua infância" 89 .

A equipe multiprofissional, por meio de estudo multidisciplinar, dispõe de instrumentos próprios para avaliar os candidatos nas entrevistas; o ideal, porém, é que a avaliação amplie os sujeitos de observação, para incluir outros filhos, pais e colaterais, para se descobrir se há real aceitação de um novo integrante da família e para obter subsídios sobre os relacionamentos pessoais dos candidatos.

Somente o exame cuidadoso do caso concreto pode afirmar a idoneidade afetiva; não cabem juízos de valor apriorísticos, que excluam arranjos familiares nãoortodoxos ou, candidatos homossexuais.

Ressalte-se que, em tema disputa de guarda entre os pais, muito já se estudou acerca do conceito do best interest of child. A jurisprudência norte-americana evoluiu da "Tender Years Doctrine" (doutrina da tenra idade), que impunha a preferência materna, para a teoria do tie breaker, ou teoria da neutralidade. A evolução foi no sentido da análise do caso concreto.

Por fim, o requisito da motivação é muito importante. Não vai longe o tempo em que as pessoas viam na adoção a finalidade caritativa, e adotavam por dó, para pagar promessas ou para salvar algum infante exposto. Não agiam imbuídos do desejo de

esso non va confusi com gli altri. In sostanza questa è la tesi: non solo si può mantenere, istruire ed educare con o senza affetto, mas l'affetto (sotto il dúplice profilo di 'idoneità affettiva' e di 'diritto all'affetto'), è qualcosa di assolutamente diverso, ma anche di fondamentale, ai fini del rapporto genitori-figli e cio non solo nella famiglia adottiva (che è um rimedio) ma anche nella famiglia (di origine) che è la formazione sociale funzionalmente predisposta a garantire la realizzazione dell'i interesse di tutti i figli minori”.

88 A. GIBBENS (1938), filósofo social inglês, considerado por muitos o maior de nosso tempo, desenvolveu a "Teoria da Estruturação" (análise da contribuição dos indivíduos e das forças sociais para moldar a realidade social) e a teoria da "Terceira Via" (ciência política).

${ }^{89}$ A. GIBBENS, A Transformação da intimidade, São Paulo, UNESP, 1990, p.118 e ss. 
ter um filho ou de ter mais um filho; em geral, essas crianças assim admitidas acabavam por ser tratadas como filhos de segunda classe.

Forte na dignidade da pessoa humana, o ECA reservou para a adoção uma única e nobre finalidade: a de constituir vínculos plenos de filiação, para criar ou completar famílias.

17.2 O vínculo entre família biológica e escolhidos para adotar

A qualidade do vínculo entre família biológica e família adotiva também é relevante para as da adoção em proporcionar bem-estar à criança.

O Estatuto excluiu peremptoriamente a entrega argentária (com intuito de obter vantagem material), e tipificou a conduta como crime em seu art. 238 ("Prometer ou efetivar a entrega de filho ou pupilo a terceiro, mediante paga ou recompensa: Pena reclusão de um a quatro anos, e multa. Parágrafo único. Incide nas mesmas penas quem oferece ou efetiva a paga ou recompensa").

Assim, se a mãe biológica entrega a criança na expectativa de obter vantagens materiais para si própria, não terá agido com o intuito de preservar o bem-estar do filho; a conclusão inevitável é a de que ela não viu na escolha dos adotantes sua oportunidade única de exercer a maternidade, e que não os escolheu em virtude de uma virtude pessoal ou social apreciada.

A criança deverá ser desde logo retirada da guarda fática dos indicados e encaminhada a pessoa cadastrado, estando desde logo autorizada a propositura da ação de destituição do poder familiar (a reificação, conduta de tratar o filho como coisa, é uma imoralidade que não se coaduna com o exercício responsável desse poder-dever).

Segundo M. MINAHIN, a reprovação à conduta decorre do "aviltamento do pátrio poder ou da tutela"90.

Interessante observar que o direito francês prevê, para a hipótese de desinteresse pela criança (que estiver em entidade ou acomodada junto a família acolhedora provisória), o suprimento judicial do que se denomina "recusa abusiva ao consentimento". ${ }^{91}$, como forma de agilizar a colocação adotiva..

\footnotetext{
${ }^{90}$ M. CURY e outros, Comentários ao Estatuto da Criança e do Adolescente, t, p.722.

${ }^{91}$ R. CRÔNE et alii, L'adoption - Aspects internes et internationaux, Defrénois, 2006, p.41.
} 
É possível considerar a indiferença como ofensa muito menos grave do que o intuito de obter vantagem pessoal com a entrega do filho; daí se cogitar desde logo de destituição do poder familiar.

É obrigatório atentar, ainda, para a freqüência das intermediações habituais ${ }^{92}$ no âmbito das adoções, a criar quase que um mercado. São as conhecidas cegonhas, como as refere S. KUSANO. Em tal situação, fica claro que a escolha dos adotantes não se fez segundo um critério de confiança, de apreço às virtudes pessoais e sociais dos eleitos; é caso de desconsiderá-la sem cerimônia, se não houver prejuízo à criança.

Inúmeros outros aspectos reclamam atenção, especialmente para efeito do do estudo psicossocial, como possíveis ambigüidades, sentimentos conflituosos, gratidão que pode vir a se transformar em chantage $m$ etc. $O$ profissional deve antecipar os desconfortos que podem advir à criança no futuro e necessariamente considerá-los em sua opinião.

17.3 A perspectiva da institucionalização da criança

A institucionalização de crianças nos primeiros meses deve ser evitada a qualquer custo. Bebês institucionalizados ficam aos cuidados de pajens profissionais, que se revezam e dividem a atenção entre diversas crianças. A situação é prejudicial, mormente se se considerar que a permanência junto à mãe e ao pai nos primeiros tempos de vida recebeu status de direito constitucionalmente assegurado.

CESARINO JUNIOR entendia que o subsídio- maternidade, antecedente da licença-maternidade de hoje, decorria de preceitos ginergiátricos (de medicina do trabalho da mulher), garantindo-lhe gozar de descansos antes e depois do parto. ${ }^{93}$ A legislação precursora foi a Constituição de 16 de julho de 1934 , no art. $121, \S 1^{\circ}$., letra $h$, que instituía a assistência médica e sanitária à gestante, antes e depois do parto.

Essa idéia, porém, evoluiu. Ao prever como direito social a licençapaternidade (art. $7^{\circ}, \mathrm{XIX}$ ), destituída de qualquer suporte orgânico, a Constituição Federal de 1988 não fez mais do que reconhecer a importância vital dos primeiros dias do pai junto ao recém-nascido, a benefício da família. Também a licença-maternidade, prevista no inciso imediatamente anterior (art. $7^{\circ}$., XVIII) é compreendida hoje como um benefício

\footnotetext{
92 Op. cit., p. 181.

${ }^{93}$ Seguro-maternidade em direito comparado, São Paulo, RT, 1961, p. 92.
} 
instituído mais em favor do recém-nascido do que em favor da mulher, tendo-se em conta a obrigatoriedade do gozo efetivo, não se admitindo indenização total ou parcial em dinheiro.

A ciência médica e a psicologia mostram que o acolhimento - acomodação física junto à mãe ou quem lhe faça as vezes - é fundamental nos primeiros dias de vida. A experiência é estruturante da personalidade da criança. A estimulação recebida nos primeiros meses responde pela capacidade cognitiva e desempenho motor do indivíduo.

Na França, as idéias da psicanalista Françoise DOLTO (1908-1988) acerca da relevância da dimensão psíquica das crianças pequenas e da necessidade do acolhimento logo nos primeiros dias de vida, apontaram também o caminho da substituição materna ou apadrinhamento ("parrainage") como mais adequado, em lugar das impessoais instituições de abrigo ${ }^{94}$.

F. DOLTO assim resumiu seu pensamento:

"Nada é pior para uma criança cuja mãe não tem condições de criá-la do que ser confiada a uma instituição de cuidados mercenários múltiplos e sucessivos, quando é de se esperar que a mãe ou o pai só lhe façam raras visitas.

Um ser humano necessita, pelo menos até os trinta meses, da segurança de um casal cuidadeiro responsável por ele, como se dele fosse filho, numa atmosfera contínua de cumplicidade recíproca e de iniciação à vida social de sua roda" ${ }^{95}$.

No Brasil, são notórias as dificuldades materiais e de pessoal do Poder Judiciário Estadual, a quem incumbe julgar as adoções. Uma vez que avaliações técnicas são imprescindíveis, não há como excluir a possibilidade de demora.

Preocupa, assim, que o primeiro destino de recém-nascido ou infante diretamente entregue a pessoa não cadastrada seja em verdade uma instituição de abrigo, caso se entenda que a escolha dos parentes biológicos não é possível.

Quanto aos escolhidos, o fato de não estar cadastrado significa, por óbvio, não haver sido previamente avaliado. É requisito do Estatuto e consenso geral que só podem adotar aqueles que reunirem condições estruturais, psicológicas e materiais, e bem assim tenham sido avaliados sob o prisma da motivação.

\footnotetext{
${ }^{94}$ F. DOLTO, Destinos de crianças - Adoção - Famílias - Trabalho Social, São Paulo, Martins Fontes, 2006.

${ }^{95}$ Destinos de crianças, São Paulo, Martins Fontes, 2006, p. 164.
} 
Sabe-se, porém, que o procedimento completo para ingresso no cadastro chega a demorar até um ano em algumas comarcas do Estado de São Paulo, entre avaliação psicológica, estudo social, manifestação do Ministério Público e despachos do juiz.

A avaliação determinada quando da apresentação do pedido, na clássica situação dos adotantes que deixaram a maternidade e agora querem "passar o bebê para seu nome", certamente não demorará um ano, mas dificilmente será ultimada em poucos dias.

No Estado de São Paulo, apenas para exemplificar, as dificuldades dos Setores Técnicos são bastante sérias: acúmulo extraordinário de serviço, falta de pessoal e de meios materiais, inexistência de profissional de psicologia na maioria das comarcas, que necessitam recorrer à sede da circunscrição. Raramente uma avaliação técnica virá antes de dois meses.

Se a mãe biológica não apresenta disponibilidade para reaver o bebê, não parece justo encaminhar o bebê a uma entidade de abrigo, a não ser em caso de absoluta necessidade. Todavia há um senso comum entre os profissionais que atuam no fórum juízo, Ministério Público, setores técnicos -, no sentido de que o abrigamento é preferível à entrega transitória a alguém, pois o surgimento de um vínculo mais forte e sua eventual ruptura traria maior sofrimento aos envolvidos.

Pensamos que, qualquer que seja a solução para o caso, deve-se evitar a institucionalização de recém-nascidos e bebês o mais possível.

É o terceiro critério a orientar necessariamente a análise judicial.

\subsection{Adoção intuitu personae e adoção internacional}

Sob a égide da legislação anterior, do Código Civil de 1916, não havia restrições à adoção internacional. Mesmo sem vir ao Brasil, o estrangeiro podia adotar crianças brasileiras, desde que constituísse um procurador que o representasse aqui no Cartório de Notas e assinassem a escritura de adoção conjuntamente com os pais ou a mãe solteira que quisessem entregar seu filho.

No que diz respeito aos menores sujeitos ao Código de Menores de 1979 e a autorização judicial para a adoção, estrangeiros não residentes no Brasil podiam recebê-los somente em adoção simples, ou seja, ou seja, ficavam-lhe vedadas adoção plena, delegação, guarda do poder judicial e tutela. A restrição, como se vê, não fazia muito sentido. 
A falta de disciplina restritiva, que impedia inclusive o acompanhamento das adoções realizadas, levava os Juízes de Menores à exasperação. P. L. NOGUEIRA, ao comentar o revogado Código de Menores, Defendia que ao estrangeiro só era lícito adotar o menor privado das condições essenciais em virtude de ação ou omissão dos responsáveis (menor materialmente abandonado), não as crianças carentes, que tinham pais; dizia que nós brasileiros não deveríamos jamais ostentar os títulos de "maior exportador de crianças ou de incubadeira do mundo". Em 1982, a Associação Internacional de Juízes de Menores e de Família, em seu Congresso de Amsterdã, endossou o pleito dos brasileiros presentes e aprovou a seguinte recomendação: "O Congresso deplora a prática de venda de crianças para adoção e encarece a urgência de estabelecer-se uma legislação internacional que ponha fim a tal prática. A adoção deve envolver uma investigação oficial para que se saiba como a criança foi obtida e se a adoção é o melhor para ela. A autorização para a adoção deve partir de uma autoridade judicial".

Para corrigir tais distorções, o ECA, além de submeter toda adoção de criança e adolescente a sentença judicial, regra que o art. 1623 do Código Civil reproduziu, instituiu em seu art. 31 que "a colocação em família substituta estrangeira constitui medida excepcional, somente admissível na modalidade de adoção".

A norma certamente diz respeito aos estrangeiros residentes ou domiciliados fora do país, de acordo com a remissão feita no $\S 2^{\circ}$. do art. 56 e no art. 51 do Estatuto, que aludem a essa circunstância. Não fosse assim, e o entendimento seria o mesmo, porque o art. $5^{\circ}$., caput, da Constituição Federal instituiu tratamento isonômico entre brasileiros aos estrangeiros residentes no país. Nesse sentido, aliás, a manifestação de diversos comentaristas do Estatuto. ${ }^{96}$

Estabeleceutse uma preferência do adotante nacional, destinando-se à adoção internacional somente as crianças e adolescentes que não encontrarem interessados entre nos cadastros nacionais, geralmente crianças maiores de 7 anos de idade, grupos de irmãos, ou portadoras de deficiência física ou mental. A prática mostra que não faltam interessados brasileiros em adotar recém-nascidos ou bebês.

A regra faz da adoção internacional a "excepcionalidade sobre a excepcionalidade", na dicção da educadora Maria Josefina Becker, comentarista do

\footnotetext{
96 R. J. ELIAS, Comentários ao estatuto da criança e do adolescente, Saraiva, 2004, p. 29; M. CURY e outros, Estatuto da criança e do adolescente comentado, 4${ }^{\mathrm{a}}$. ed., Malheiros, 2002, p. 126; V. ISHIDA, Estatuto da criança e do adolescente, $3^{\mathrm{a}}$.ed., Atlas, p. 67.
} 
Estatuto $^{97}$. Frustrados os esforços para manter a criança em sua família natural, deve-se ao menos tentar mantê-la em território nacional, com o que se estará evitando a perda de outras referências (para além das referências familiares), ao preservar o sentimento de pertença à nação de origem.

Esse sentimento de pertença a uma nação constitui elemento indisputável da construção da identidade pessoal, em que não se pode desprezar o elemento étnico. A excepcionalidade da adoção internacional de certa forma serve a minimizar a sujeição de crianças e adolescentes, pessoas em desenvolvimento, a preconceitos de raça e de cor. E não apenas isso. Serve para não as impedir de compartilhar do tesouro imaterial que a ancestralidade lhes conferiu, pois, segundo T. CAVARZERE, "uma nação é uma comunidade de pessoas que se tornaram conscientes de si mesmas, à medida que a história foi formando-as, que preservam como um tesouro o seu próprio passado" 98 . E serve, por fim, para não dificultar o acesso à verdade sobre sua origem.

São valores que somente cedem diante do interesse maior da criança, que é o de crescer em família, quando se verifica que não há perspectiva de colocação em lar substituto brasileiro.

É o Brasil signatário da Convenção de Haia (Convenção Relativa à Proteção das Crianças e à Cooperação em Matéria de Adoção Internacional, concluída em Haia em 29 de maio de 1993, ratificada pelo Congresso Nacional em 14 de janeiro de 1999 e promulgada em 21 de junho de 1999), que estabeleceu garantias para preservar o melhor interesse da criança e instaurou um sistema de cooperação entre os Estados Contratantes, para observância dessas garantias, com o objetivo maior de prevenir o seqüestro, a venda e o tráfico de crianças. Nesse passo, dispôs sobre a designação de uma Autoridade Central, incumbida de dar cumprimento às normas convencionais, entre as quais o credenciamento de entidades autorizadas a operar adoções, e sobre o reconhecimento e efeitos no país de domicílio dos adotantes. Esta última disposição é muito relevante, porque obrigou o país de domicílio dos adotantes a conceder a nacionalidade aos adotados.

A Autoridade Central no Brasil, por força do 3171, de 16 de setembro de 1999, é a Secretaria dos Direitos Humanos; no âmbito dos Estados, as CEJAI - Comissão Estadual Judiciária de Adoção Internacional. No Estado de São Paulo, desde o ano de 1995, por força do Provimento 12/95 da Corregedoria Geral de Justiça, vigora a

\footnotetext{
${ }^{97}$ M. CURY e outros, Estatuto da criança e do adolescente comentado - Comentários jurídicos e sociais, p. 127.

${ }^{98}$ T. CAVARZERE, Direito internacional da pessoa humana, p. 179.
} 
obrigatoriedade de prévia consulta ao Cadastro Central de Adotantes, como forma de exaurir as possibilidades de manutenção da criança em solo nacional.

Em 29 de abril de 2008, o Conselho Nacional de Justiça baixou Resolução 54, com vistas a implementar o Banco Nacional de Adoção, com os dados relativos às crianças e adolescentes disponíveis para adoção de todas as comarcas das unidades federativas, como forma de operar o Cadastro Nacional de Adoção.

A jurisprudência do E. STJ excepcionou casos, porém, em que a desconsideração da preferência não foi corrigida, porque a entrega da criança a estrangeiros estabeleceu laços afetivos, considerados prioritários. O E. STJ, nos julgados REsp 159075/SP (Rel. Ministro ARI PARGLENDER) e REsp 196.406-SP (Rel. RUY ROSADO DE AGUIAR), deixou claro, porém, "para efeito de jurisprudência e casos futuros", que a regra do art. 31 do ECA era obrigatória, ainda que os pretendentes estrangeiros ostentem melhores condições socioeconômicas do que os cadastrados.

Admitiu-se aí temperamento à regra da excepcionalidade em princípio configura norma cogente, incontornável pela vontade dos envolvidos.

Em se tratando de recém-nascido, sem que se cogite ainda da formação de laços afetivos com estranhos, cremos que um único temperamento é possível, em homenagem ao direito da personalidade que se reconhece no exercício do poder familiar.

Há de se exigir vínculo de confiança e amizade com os pretendentes, mas não qualquer amizade: antiga, importante, significativa.

Cremos, assim, que a escolha da parte dos parentes biológicos deve submeter-se a à excepcionalidade prevista na lei, somente podendo recair sobre estrangeiros se houver comprovados laços de amizade, antigos e significativos, tal qual se observaria na nomeação de tutor feita pelo homem médio.

A exigência destina-se à impedir a burla da lei, ou seja, simulação com o objetivo de desobedecer o comando legal, e mais uma vez obriga ao estudo cuidadoso das particularidades do caso.

Pensamos que outras duas exigências são impõem: o estudo psicossocial favorável; a oferta, pelo país de acolhida, da garantia da fruição dos direitos equivalentes aos que resultariam de adoção concretizada nesse Estado (art. 26, 1, c da Convenção de Haia), com vistas à futura obtenção da nacionalidade no país de acolhida, ainda que este não seja signatário da Convenção.

Observa-se inicialmente que a capacidade para adotar regula-se pela lei do lugar de domicílio do pretendente (art. $7^{\circ}$. da Lei de Introdução ao Código Civil), o que 
obriga a cometer o estudo social a órgão oficial ou agência de adoção credenciada no país de acolhida. Esse procedimento deverá estar concluído antes do deslocamento da criança. A mesma agência deverá oferecer o acompanhamento da medida pelo prazo que o Brasil fixar.

Satisfeitas essas condições, e reconhecido o vínculo importante de confiança e amizade entre família biológica e família adotiva, não será viável admitir o intuitu personae relativamente a recém- nascidos ou bebês. Enfatiza-se, de qualquer modo, que a incorporação da Convenção de Haia ao ordenamento jurídico interno (Decreto 3087, de 21 de junho de 1999), estabeleceu garantias mínimas em prol do menor sujeito a adoção internacional; tais garantias inserem-se no conceito de "cláusula pétrea" e a vontade dos adultos envolvidos não as pode contornar.

18. Acesso do filho adotivo aos dados sobre sua origem

Psicólogos e especialistas de todas as áreas recomendam aos pais adotivos que revelem ao filho adotivo sua origem, ainda nos primeiros anos de vida ${ }^{99}$, para que não este desenvolva fantasias nocivas nem se decepcione com a inevitável descoberta da verdade na adolescência. ${ }^{100}$

A identidade é uma construção. É o amálgama de herança genética, educação, vivência, sorte. Construção que se faz essencialmente através da reflexão sobre a própria história, da elaboração constante dos sentimentos à luz de experiências novas. Conhecer a própria origem, assim, é direito necessariamente inserido no âmbito do direito à afirmação da própria individualidade e à construção de uma identidade pessoal.

Repita-se que, em se tratando de pessoa que foi abandonada ou entregue em adoção, e registrou mesmo inconscientemente a rejeição inicial, o acesso às informações constitui talvez a única chance de perdoar. Especialmente em nosso país, onde se vê com frequiência a absoluta carência de meios, a impelir tantas pessoas a abandonar ou entregar seus filhos em adoção.

\footnotetext{
${ }^{99}$ L. SCHETTINI FILHO, Adoção - origem, segredo, revelação, Bagaço, p. 36.

${ }^{100}$ M. A. PISANO MOTTA, op. cit., p. 29: "A política do não acesso aos registros e da adoção fechada praticados no Brasil perpetuam o estigma e as fantasias do adotado a respeito da realidade de sua entrega em adoção, remetendo-o a um a priori do qual dificilmente escapará: "Fui abandonado", "Não me quiseram", "Devo ser uma pessoa horrível pois fui rejeitado pela minha própria mãe”, "Minha mãe deve ser uma pessoa muito má pois rejeitou seu próprio filho".
} 
E perdoar é também um processo vital. ${ }^{101}$

Do ponto de vista jurídico, como imaginar que algumas pessoas, mais do que outras, fiquem privadas da busca de informações sobre sua origem biológica e sua história? Impossível admiti-lo, quando se sabe que a recusa equivale a impedir o acesso não apenas ao pai ou mãe em si, mas às motivações do abandono. Essa motivação pode compreender fato relevante, suscetível de se compreendido e perdoado, de modo a conferir paz de espírito aos envolvidos.

Não há como conferir, nos dias de hoje, o direito ao anonimato à mulher que dá à luz um filho e não o reconhece, como se ainda estivéssemos nos tempos da Roda dos Enjeitados. E mesmo que o suposto direito pudesse vir a ser reconhecido, não sobrelevaria o direito do filho em conhecer sua própria origem. O direito à construção da identidade se sobrepõe ao direito à privacidade.

Não há dúvida de que, nos dias de hoje, em que o DNA e a hereditariedade ocupam o pensamento geral, conhecer a ancestralidade deve ser alçado à categoria de direito da personalidade.

Pode-se dizer que o mistério da existência humana é relativizado pelo sentimento de pertença a uma família, a um clã, a uma nação. Fundamental a crença na estirpe, tanto que sempre existiu o culto aos ancestrais, prática que tenha talvez conhecido seu apogeu nas civilizações mediterrâneas da Antigüidade. Refazer os caminhos dos antepassados, percorrer rotas de imigração e descobrir parentes, são atividades de que muitos se ocupam atualmente. A vontade atávica de sentir-se pertencer explica desde o gosto pela heráldica e o estudo da genealogia até os arraigados sentimentos de patriotismo.

E não apenas. A descoberta do DNA submeteu tanto a ciência como as consciências ao dogma da hereditariedade. Se todos os dias somos confrontados com o anúncio de que características físicas, doenças e mesmo tendências comportamentais derivam da conformação de determinados genes, o acesso à origem biológica, ao pai e à mãe de sangue, tornou-se ainda mais relevante.

Experimentamos momento de grande progresso tecnológico acompanhado de “imprecisão ética”. As múltiplas possibilidades de manipulação genética tornaram

101 Para H. ARENDT, “...o perdão é a única reação que não re-age apenas, mas age de novo $e$ inesperadamente, sem ser condicionada pelo ato que a provocou e de cujas conseqüências liberta tanto o que perdoa quanto o que é perdoado. A desobrigação mencionada nos ensinamentos de Jesus sobre o perdão é a libertação dos grilhões da vingança, uma vez que esta prende executor e vítima no inexorável automatismo do processo da ação que, por si, jamais chega necessariamente a um fim." (A condição humana, Forense, 2a ${ }^{\mathrm{a}}$. Edição, 1983, p. 253). 
realidade, há muito, uma série de fenômenos como seqüenciamento de DNA, determinação artificial do sexo de embriões, fertilizações heterólogas, sub-rogação do ventre (prática popularmente conhecida como "barriga de aluguel"), congelamento de embriões. Sem que a comunidade científica se preocupasse com a fixação de limites éticos à experimentação, e diante da falta de agilidade dos ordenamentos jurídicos nacionais em oferecer disciplina normativa, era previsível que adviessem conseqüências nocivas, como o patenteamento de informações genéticas, para efeito de venda clandestina (sabe-se, por exemplo, que nos Estados Unidos hospitais e maternidades vendiam amostras de sangue a companhias seguradoras). Abriu-se nova porta para práticas discriminatórias no mercado de trabalho e no acesso a assistência médica, clonagem humana, entre outras tantas..

Preocupado com a questão há décadas, N. BOBBIO aludiu expressamente a uma categoria nova de direitos fundamentais: "mas já se apresentam novas exigências que só poderiam chamar-se de direitos de quarta geração, referentes aos efeitos cada vez mais traumáticos da pesquisa biológica, que permitirá manipulações do patrimônio genético de cada indivíduo". 102

A afirmação do direito que toda pessoa tem em conhecer a própria origem torna-se essencialmente problemática diante do indivíduo que tenha sido adotado em pequeno ou que tenha nascido em decorrência de fertilização heteróloga em procedimento de reprodução assistida.

Não existem garantias suficientes ao exercício desse direito no Brasil.

Para a mulher que entrega seu filho recém-nascido em adoção, o acesso deste aos registros no futuro (autos do processo judicial) pode constituir perspectiva temível, angustiosa, ou a esperança de compreensão de seu gesto. A matéria não está prevista em nossa legislação, diferentemente do que ocorre em diversos outros países.

$\mathrm{Na}$ Inglaterra, foi promulgado na década de 70 o 'Revelation Act', que dava acesso aos interessados aos registros de adoção até então mantidos em sigilo. Como era de se prever, o ato permitiu que um sem-número de filhos adotivos, desejosos de conhecer sua história, saíssem em busca de seus por pais biológicos.

Na Itália, a Lei 184 dispõe que o menor adotado será informado da sua condição na forma e oportunidade que os pais adotivos acharem mais conveniente. Concede ao adotado que completar 25 anos o direito de acesso às informações sobre a origem e identidade do pai biológico. Porém esse é um direito "reconhecido pela metade",

\footnotetext{
${ }^{102}$ A era dos direitos, Rio de Janeiro, Campus, 1992, p. 6.
} 
já que a lei excepciona os casos em que um dos pais biológicos tenha declarado preferir se manter no anonimato, ou haja consentido sob essa condição.

A partir da $2^{a}$. Guerra Mundial, a França concedeu às mulheres a faculdade de dar à luz no anonimato, sem que seu nome constasse de registros hospitalares ou do registro civil, dando ensejo às numerosas crianças registradas como "accouchées sous $x$ ".

A Suécia implementou o "Modelo Anti-segredo" na década de 80, fundado na opinião de especialistas de que a transparência faz os filhos adotivos são mais felizes. Além disso, a Suécia foi o primeiro país no mundo a adotar uma lei abrangente acerca de inseminação artificial. Vigora também aí a transparência, uma vez que, segundo as autoridades da Comissão sobre Inseminação Artificial, os nascimentos por inseminação "não devem ser considerados inimagináveis e não mais incomuns do que adoção".

A lei sueca, assim, eliminou o anonimato, garantindo a toda pessoa o direito de examinar registros hospitalares com vistas a identificar seu pai ou mãe biológicos.

103

G. MONACO analisou o tema no que concerne às adoções internacionais e concluiu que os países de acolhida tendem a se filiar ao sistema de abertura de dados. Sobre os instrumentos internacionais, porém, concluiu: 'Os instrumentos internacionais não são claros a esse respeito. Em um primeiro momento parecem aderir ao sistema da conficialidade dos dados para, posteriormente, abrirem a possibilidade do conhecimento de tais dados." 104 .

No Brasil, mesmo a obtenção de uma certidão de nascimento em inteiro teor submete-se à discricionariedade do Juiz Corregedor do Registro Civil, visto que o artigo 47, par. $4^{\circ}$., emprega a vaga expressão "para a salvaguarda de direitos". Já o acesso aos autos judiciais, conquanto não exista proibição, fica prejudicado pelas deficiências nas anotações e registros, muitas vezes feitas apenas no nome original do menor antes de adotado. Não bastasse isso, como solução ao grave problema dos arquivos abarrotados e dispendiosos, cogita-se no Estado de São Paulo a substituição desse sistema pela entrega dos autos às partes, caso em que ficariam sujeitos a extravio e destruição. Possivelmente os procedimentos da adoção devessem ser excetuados da medida, ante a relevância do direito a conhecer a própria origem.

\footnotetext{
103 G. EWERLÖF, juiz e secretário da Comissão sobre Inseminação Artificial, declarou em $1^{\circ}$. de março de 1985: "It is to be hoped that future artificial inseminations will be more candid and open than they have been until now. The objective should be to ensure that birth by insemination is not unthinkable and indeed no more unusual than adoption. In matters of adoption Sweden has long since abandoned secrecy and mistery. According to specialists in adoption, this has helped to make adoptive children happier." (in Ariés, Philippe, 104 G. MONACO, Direitos da criança e adoção internacional, RT, 2002, p. 130.
} 
Anote-se que o Projeto de Lei 1756/03 inova ao assegurar o direito à revelação da condição de filho adotivo.

\section{CAPÍTULO IV -- DIREITO ESTRANGEIRO}

Sem a intenção de incorrer propriamente no direito comparado, mas apenas de apresentar sistemas opostos em países estrangeiros, procedemos a alguns apontamentos relativamente a Estados Unidos e França.

\section{Estados Unidos}

Nos Estados Unidos, a forma de federação e o sistema jurídico, que é do direito consuetudinário ("common law”) impõem a diversidade de ordenamentos jurídicos estaduais aplicáveis em tema de adoça; recentemente se verificou o esforço do governo federal em uniformizar os procedimentos.

Nos Estados Unidos só existe uma única espécie de adoção, que corresponde à adoção Estatutária brasileira e à adoção plena francesa.

A grande procura por adoções em meados do século XX, e a existência de cada vez menos crianças adotáveis, são os motivos que progressivamente impeliram os Estados ao sistema das adoções abertas ("open adoptions"). Acreditava-se que a adoção aberta, ao não subtrair de todo o acesso ao filho, estimularia os pais biológicos a consentir nas adoções. 105

Mais amplo do que a mera admissão do intuitu personae, o sistema de adoções abertas pressupõe a atuação de agências credenciadas, oficiais ou particulares. A função dessas agências consiste em orientar e avaliar interessados, e formar banco de dados, com a finalidade de apresentá-los a mulheres que desejam entregar o filho que estão gerando. No curso da gestação, a mulher recebe os perfis e documentação de casais ou indivíduos interessados, e aí escolhe um ou vários deles para entrevistas. Em geral, os escolhidos passam a acompanhar a gravidez e se fazem presentes no momento do parto.

${ }^{105}$ FINE, Agnes e NEIRINK, Claire, Parents de sang - Parents adoptifs, L.G.D.J, 2000, p. 153 
Segue-se troca de fotografias, além de acompanhamento, encontros, tudo de acordo com o que ficou acordado.

À adoção que se desenvolve sem a intermediação de uma agência, dá-se o nome de adoção independente.

A forma judicial é necessária e a escolha dos pais (intuitu personae), respeitada.

Parece claro que, nesses casos, não há espaço para segredo, que parece não ser tão valorizado na cultura norte-americana contemporânea.

Conquanto esse seja o modelo do direito norte-americano, a Convenção de Haia, aprovada pelo Decreto Legislativo 63, de 19 de abril de 1995, forte no combate ao comércio e tráfico de seres humanos, estabelece como princípio que o contato posterior é indesejável. Eis o teor de seu artigo 29: “Não deverá haver nenhum contato entre os futuros pais adotivos e os pais da criança ou qualquer outra pessoa que detenha a sua guarda até que se tenham cumprido as disposições do Artigo 4, alíneas a e c do Artigo 5, alínea a, salvo os casos em que a adoção for efetuada entre membros de uma mesma família ou em que as condições fixadas pela autoridade competente do Estado de origem forem cumpridas".

\section{França}

Na França convivem duas espécies de adoção, plena (plenière) e simples (simple), mas a adoção plena seja muito mais comum. Com efeito, os estudiosos não se conformam que a Lei de 1966 tenha conservado a modalidade simples, que não rompe definitivamente os laços com a família de sangue e pode ensejar superposição de direitos de titulares distintos sobre o mesmo adotado.

O consentimento para adoção está previsto no Código Civil. Em se tratando de criança maior de dois anos, o pai ou a mãe só serão admitidos a prestá-lo se a criança não estiver aos cuidados do serviço social da Infância, abrigada ou acomodada com a família substituta provisória (384-4). Isso se explica na presunção de negligência ou violência contra a pessoa do filho que esteja institucionalizado.

Se a criança é menor de dois anos, porém, os pais só poderão consentir na adoção se a criança estiver abrigada, ou aos cuidados do serviço social (artigo 348-5 do Código Civil). A lei comete ao serviço social da Infância (aide social) a tarefa de 
colocação familiar das crianças pequenas, excetuado o caso das adoções intrafamiliares (parentela de até sexto grau)

Conquanto não haja proibição expressa, os doutrinadores entendem que a interpretação conjunta dos dois dispositivos exclui a possibilidade de escolha dos adotantes pelos pais biológicos ('En France, la combinaison de deux dispositions, contenues dans lês articles 348-5(a) e 384-4(b) du Code civil, s'oppose au libre choix, par le parents biologiques, des adotants" $\left.{ }^{106}\right)$.

O prazo para arrependimento é de dois meses, e a forma não é necessariamente judicial.

Se se patentear o desinteresse pela criança, o recusa em consentir em sua adoção pode ser considerada abusiva, e objeto de suprimento judicial.

A adoção simples é revogável, ao contrário da adoção plena. Aos pais de sangue é conferida a legitimidade para pleitear o desfazimento do vínculo adotivo.

Anota-se que na França existe um contingente pequeno de crianças a adotar e que a assistência social é muito bem estruturada

${ }^{106}$ op. cit., p. 155 


\section{CAPÍTULO V - OUTROS TEMAS}

\section{Adoção de Nascituro}

Sobre a adoção de nascituro, A. CHAVES, diante da alteração que a Lei 3133/57 introduziu no art. 372 do Código Civil de 1916, qualificou o resultado de "contrasenso sob o ponto de vista humano e sob o ponto-de-vista legal" ${ }^{\prime 107}$. Para livrar-se inconveniência da lei, apegou-se ele a argumento atificial: uma vez que nascituro não começou a existir juridicamente e nem tem idade, não estaria satisfeito o requisito da diferença mínima de 16 anos.

Ao tratar de filiação, M.. BOSCARO ${ }^{108}$ registrou a existência de diversas correntes de pensamento, apontando que o núcleo central dos argumentos contrários à adoção de nascituro era a ausência de disciplina específica no Estatuto da Criança e do Adolescente.

Com o advento do Código Civil de 2002 e a superposição de regras, a desafiar o já mencionado "diálogo das fontes”, a situação se complicou sobremaneira.

Não há dúvida de que o nascituro é sujeito de direitos, como o direito ao pai, à identidade genética, à indenização por morte de seu pai, a alimentos, à imagem e à honra, como os enumerou M. HELENA DINIZ, sem pretender erigi-los em rol taxativo. ${ }^{109}$

S. CHINELATO, entusiasta dos direitos do nascituro, entende perfeitamente possível sua adoção, cuja utilidade seria a mesma que embasa o reconhecimento pré-natal. Entende que o "direito a alimentos e à saúde - o primeiro, relacionado ao direito à vida, $e$ o segundo, à integridade física, ambos direitos da personalidade - por si sós justificam a permanência do instituto da adoção do concebido. Esses direitos do nascituro serão assegurados pela adequada assistência pré-natal, que o adotante deverá propiciar, desde a adoção".

No âmbito estreito desde estudo, em que não se pretende esgotar a matéria, entendemos que somente a adoção unilateral pode recair sobre o nascituro. Se, ao contrário, o pressuposto for a separação entre mãe e filho, a adoção é impossível. Conquanto não se reconheça o direito do nascituro à acolhida em família substituta no caso

\footnotetext{
107 op. cit., p. 615

${ }^{108}$ Direito de Filiação, RT, 2002, p. 87.

${ }^{109}$ Vide “O Estado Atual do Biodireito", 4 ${ }^{\mathrm{a}}$. ed., 2007, p. 121
} 
de futura desistência ou rejeição materna, até anunciada no curso da gravidez, não se pode esquecer que à mãe biológica $\mathbf{e}$ reconhece o direito subjetivo do arrependimento, da retratação da promessa de entrega do filho. É direito que se reconhece tout court, sem exigências, e exercitável até o trânsito em julgado da sentença concessiva da adoção.

A substancial diferença entre o vínculo ('rapport”) que se estabelece entre a mulher grávida e seu embrião ou feto, e o vínculo entre a mulher que deu à luz e seu filho, dispensa maiores digressões. Apenas se considere que, antes do nascimento, não existia senão expectativa, muitas vezes influenciada pelo temor, risco real ou imaginário, de abortamento; após o nascimento está-se diante de uma realidade perfeita, de uma pessoa capaz de interagir.

Cremos que por essas razões, a Convenção de Haia, forte na proteção da dignidade da pessoa humana, a Convenção de Haia estabeleceu como requisito de validade das adoções internacionais que "o consentimento da mãe, quando exigido, tenha sido manifestado após o nascimento da criança" (art. $\left.4^{\circ} ., d\right)$.

Lembre-se, por fim, que nos casos em que a mulher grávida tiver o fundado receio de morte no parto ou logo após, a adoção também não se apresenta como o remédio jurídico apropriado para a proteção da pessoa por nascer, sendo muito mais lógico aventar, para o evento futuro e incerto do óbito, a nomeação de tutor prevista no parágrafo único do artigo 1729 do Código Civil.

A solução já era prevista no Direito Romano, nas Institutas de Gaio (G.1, 146): “147. Como todavia, em muitos outros casos, os filhos póstumos sejam havidos como já nados, decidiu-se também, em tal caso, ser possível nomear tutor, em testamento, aos póstumos, assim como aos já nascidos, contanto que estejam na situação de, nascendo durante nossa vida, caírem sob nosso poder" 110.

22. Caráter relativo da ordem cronológica de inscrição no cadastro

A regra do art. 50 do Estatuto, que instituiu os cadastros de interessados em adotar, deu margem a acendrada discussão acerca da possibilidade de discricionariedade judicial no manejo do cadastro, que, na vigência do princípio constitucional da isonomia, em regra somente comportaria a estrita observância da ordem cronológica de inscrição.

Conquanto a lei eleja claramente a prevalência do superior interesse da criança, a discussão parece ser de grande valia, pois há juízes que entendem que o critério

${ }^{110}$ CORREIA, Alexandre e SCIASCIA, Gaetano, Direito Romano 2, Saraiva, 1955, p. 61 
cronológico de inscrição dos interessados é absoluto, muitas vezes com argumentos de caráter quase místico, enquanto outros admitem a inobservância da ordem do cadastro.

Tanto é assim que o Estado de Santa Catarina mantém a prática de publicar o "andamento da fila", disponibilizando senhas aos cadastrados para que o acompanhem por Internet e de algum modo divulgando o perfil dos adotados. Isso significa reconhecer implicitamente, a todos os que sentirem preteridos, o direito a impetrar mandados de segurança - conexos a procedimentos que, é paradoxal, tramitam sob Segredo de Justiça.

C. E. PACCHI, lançando mão do argumento de que o Estatuto pretende encontrar uma família para a criança e não o inverso, entende que a ordem cronológica pode ser excepcionalmente desconsiderada (obra citada, p. 167).

Em nosso entendimento, não se trata de absolutamente de licitação, de modo que o critério puramente objetivo pode não ser suficiente. Há que priorizar os vínculos de afeto, caso existam (caso vínculos surgidos antes ou durante a permanência no abrigo). Não se pode excluir, ainda em caráter excepcional, a possibilidade de análise do perfil dos cadastrados, para escolha da melhor colocação para determinada criança que se encontre em situações peculiares (recém-nascidos com características raciais indefinidas devem ser colocados junto a casais que desde o início hajam manifestado indiferença à cor; crianças com determinadas doenças ou síndromes devem ser colocadas junto a quem tenha efetivas condições materiais de proporcionar o tratamento médico específico, etc...).

Registre-se que o Projeto de Lei não dispõe sobre a questão. No entanto prevê, em seu artigo $8^{\circ}$, que somente será deferida adoção em favor de candidato brasileiro não inscrito no cadastro "quando se tratar do pedido de adoção unilateral, ou formulada por parente próximo, ou com adesão expressa dos genitores, ou quando se tratar de guarda fática, em que o lapso do tempo de convivência comprove a fixação de laços de afinidade e afetividade".

\section{Restrições à escolha do perfil da criança}

Faz-se necessário analisar, do ponto de vista jurídico, a legalidade de providência, emanada de juízes de direito ou Corregedorias Gerais de Justiça, de abolir a possibilidade de escolha do perfil de criança por parte dos interessados em adotar, uma vez que nem Estatuto da Criança e do Adolescente nem o Projeto da Lei de Adoção conferem tratamento analítico aos requisitos para ingresso no cadastro. 
Convém recordar a polêmica que se iniciou no ano de 2004, quando o magistrado titular de Vara da Infância e Juventude do Rio de Janeiro baixou portaria que suspendia a prerrogativa, das pessoas interessadas em adotar, de escolher sexo, idade e características raciais da criança desejada.

Certamente tomou essa decisão animado dos mais generosos objetivos, preocupado com a grande quantidade de crianças maiores de quatro anos, em sua maioria negras ou pardas, que vivem nos abrigos da cidade do Rio de Janeiro. Eentendeu que, privados da escolha, os interessados em adotar ficariam naturalmente propensos a acolher tais crianças.

Essa premissa, porém, não se mostra verdadeira, e as conseqüências da restrição nos parecem preocupantes.

Em primeiro lugar, é preciso compreender que a adoção não pode ser vista como solução para o grave problema social das crianças abrigadas. E acordar para a realidade de nosso país: conquanto o Estatuto da Criança e do Adolescente expressamente diga que a pobreza não é motivo para a perda do poder familiar, o fato é que grande parte, talvez a maior parte das crianças em abrigos, provém de famílias paupérrimas, que não contam com um mínimo de renda e de condições de habitabilidade, sendo essa a raiz do abandono e da negligência. Tal criança está abrigada porque o Estado falhou na estruturação de programas de auxílio capazes de prevenir o abandono. Mas se o Estado falhou antes, deveria falhar menos na tarefa de reintegração familiar. E uma vez corrigida a situação de extrema miséria, a criança deveria voltar ao convívio de seus próprios familiares e recuperar os vínculos de afeto que a estruturaram.

A adoção não se compadece com fins caritativos, sociais. É antes de tudo um acontecimento privado, adstrito ao âmbito familiar. É um ato de amor que deve equacionar o desejo dos adultos em exercerem o papel de pai e mãe e a necessidade da criança em ter uma família. Se o desejo dos primeiros não for considerado, há o risco de uma adoção malfeita, de uma decepção, de vida familiar infeliz.

Cada um tem seu sonho. Para muitos, vivenciar a fase das fraldas e mamadeiras, dos primeiros passos e das primeiras palavras, pode ser essencial. Cada um conhece suas limitações, inclusive. Num mundo de homens e mulheres ideais, certamente não existiriam. Mas dentro de nossa realidade, acolher uma criança de seis ou sete anos que já tem sua história, seus traumas, sua personalidade definida - pode representar imensa dificuldade de adaptação, talvez insuperável para alguns casais. E a questão racial é ainda mais delicada. A sociedade brasileira é, sim, preconceituosa, e sempre que pode mostra sua 
repulsa ao diferente. Muitas vezes, como enfrentar o preconceito dos próprios familiares, como avós e tios, e correr o risco de expor uma criança?

É óbvio que todas as crianças, qualquer que seja a idade e a cor da pele, têm igual direito a uma família. Para se atingir esse objetivo, é desejável que se crie uma "cultura da adoção", para que as pessoas em geral, e não apenas os pretendentes cadastrados, sejam conscientizados da situação real do instituto, tenham condições de enfrentar seus temores e "abrir seus horizontes". Para tanto, relevantíssimo o papel dos Grupos de Apoio à Adoção, que constituem foro privilegiado para a reflexão e o amadurecimento de projetos de vida.

Mas substituir a conscientização por uma medida de força, que sumariamente desconsidera o desejo dos adotantes, nem é capaz de promover real impacto sobre a cultura da adoção em nosso país nem contribuirá para a busca da adoção legal, deixando caminho aberto à prática preocupante da chamada “adoção à brasileira". 


\section{CONCLUSÕES}

As adoções impropriamente denominadas "à brasileira" eram muito comuns até há alguns anos, ao menos até a introdução de tecnologias que aperfeiçoaram o sistema de registros públicos, e deviam-se principalmente à cultura arraigada, própria da peculiar formação da nossa gente, pródiga de "filhos de criação" e agregados, e a mitos e preconceitos contra a adoção, que justificariam revesti-la de segredos.

Nos dias de hoje, em que o acesso a exames de DNA se vulgarizou, o pretendido segredo tornourse ilusório, impossível. Além de maiores dificuldades em fraudar o registro de nascimento e dos exames genéticos que fazem da adoção nãorevelada uma mentira de "perna curta', certamente existe hoje maior consciência ética, a exigir que as adoções se façam em conformidade com a lei. Para adotar crianças, é ao fórum que os pretendentes devem se dirigir; e então se submeter a provas e entrevistas, com o fim de qualificar-se para inscrição num cadastro oficial; para em seguida agua rdar sua vez, em espera que pode parecer interminável.

Seja porque cederam à tentação de atalhar o caminho ao conhecer alguma mulher pobre e grávida, disposta a lhes entregar o filho que decidiu não criar, assumindo eles os riscos do arrependimento, seja porque a vida é sempre muito mais complexa e pode apresentar situações não previstas, o fato é que a todo tempo aportam aos fóruns trios angustiados - mãe biológica, casal pretendente, recém-nascido - , para pedir que se formalize a entrega já efetivada.

As respostas judiciais são muito díspares.

Existe a idéia de que a entrega de filho para adoção, prevista no $\S 1^{\circ}$. do art. 45 do ECA, equivale a abandono ou a "renúncia do irrenunciável", ou seja, a comportamento socialmente condenável. À mulher que dá à luz um filho que não pode ou não quer criar estão associadas características negativas como apatia, indiferença ou frieza. Em conseqüência, doutrina e jurisprudência relutam reconhecer a essa mulher, no sistema da adoção estatutária, em que o caráter publicístico é mais forte, o direito de indicar o adotante de seu filho.

Todavia não se sustenta a idéia da irrenunciabilidade do poder familiar, uma vez que o nosso direito positivo contempla a figura do consentimento para adotar, como o fazem a maioria dos sistemas jurídicos nacionais ocidentais e o fizeram ao longo da história. Mais correto, talvez, dizer do poder familiar não é irrenunciável, mas é incoercível, em virtude da natureza própria de direito à personalidade. 
Outros entendem que a ordem legal para a criação de cadastros de interessados em adotar significaria impedir pessoa não-cadastrada de adotar.

A interpretação sistemática do Estatuto exclui esse entendimento, pois, em verdade, o consentimento em favor de pessoa não-cadastrada não está previsto e nem está proibido. Abre-se espaço para o juízo de conveniência, no âmbito de exercício eqüitativo da jurisdição.

Para decidir se a adoção proposta é ou não favorável, é preciso analisar diversos critérios, dentre os quais a efetiva confiança da mãe biológica nas pessoas que indicou. É muito importante para ela entregar-lhes o filho, e não para outros? Sua escolha se deu em função de qualidades que ela aprecia ou admira? A entrega a pessoa de sua confiança constitui a única forma que lhe é possível de exercer a maternidade? A entrega a pessoa de sua confiança constitui um fato de tranqüilidade? Sua intransigência submeteria a criança a tempo significativo de institucionalização, a espera pela destituição do poder familiar?

As respostas a essas questões servirão à descoberta, válida para o caso determinado, da dimensão concreta do melhor interesse da criança e da possibilidade de compatibilizá-lo com a efetiva proteção da dignidade humana, igualmente reconhecida na pessoa da mãe.

Eis as nossas conclusões:

1. O consentimento para colocação em família substituta é instituto peculiar do direito de família e não se confunde com renúncia ou abandono;

2. O puerpério não impede o consentimento, mas recomenda que a autoridade judiciária submeta a mulher a avaliação psicológica;

3. O consentimento só pode ter por objeto criança já nascida;

4. O consentimento prescinde de homologação judicial;

5. O arrependimento pode ser manifestado somente até o trânsito em julgado da sentença constitutiva da adoção;

6. A lei brasileira não proíbe a adoção direta ou intuitu personae;

7. A exigência legal de formação de cadastro de interessados em adotar não exclui a possibilidade de escolha dos adotantes pelos pais biológicos;

8. A adoção intuitu personae não é necessariamente ncompatível com a efetivação do "melhor interesse da criança";

9. A escolha pelos pais biológicos assemelha-se à nomeação de tutor; 
10. A escolha pelos pais biológicos não pode ser admitida se implicar prejuízo ao "melhor interesse da criança";

11. Não há como estabelecer juízo apriorístico acerca do benefício da escolha, exigindo-se o estudo social caso a caso;

12. Se a escolha dos pais biológicos recair sobre estrangeiro residente fora do Brasil, a avaliação judicial há de ser restritiva, exigindo-se prova de vínculo de afeto antigo e importante entre uns e outro;

13. A adoção intuitu personae enseja procedimento de judicial de jurisdição voluntária;

14. A avaliação da conformidade do intuitu personae com o superior interesse da criança envolve os seguintes aspectos: 1) condições materiais e psicológicas dos adotantes; 2) existência de contato entre genitores biológicos e adotantes e consequiências prováveis desse contato; 3) possibilidade de redução ao mínimo do tempo de espera em instituição;

15. A decisão judicial baseada na eqüidade não dispensa fundamentação suficiente, e a decisão judicial em caráter definitivo há de ser necessariamente precedida de avaliação da equipe multidisciplinar prevista no art. 150 do ECA;

16. A atividade da autoridade judiciária deverá minimizar o tempo de institucionalização, em especial de recém-nascidos e infantes de até dois anos de idade, porque o acolhimento materno constitui direito fundamental previsto no art. 7, XVIII, da Constituição Federal;

17. O acesso à verdade sbre a própria origem é direito fundamental do indivíduo;

18. É dever do Estado preservar os registros de todas as adoções e garantir seu acesso aos adotados, após sua maioridade;

19. A admissibilidade da adoção intuitu personae serve ao propósito de evitar as indesejadas adoções mediante fraude registrária (art. 242 do CP);

20. Eventuais restrições, por parte de autoridade judiciária ou executiva, à escolha do perfil de crianças a adotar, constituem equívoco que conduz inevitavelmente às adoções diretas e fraudulentas. 


\section{REFERÊNCIAS BIBLIOGRÁFICAS}

ALMEIDA JUNIOR, A. e COSTA JUNIOR, J.B. de O, Lições de Medicina Legal, 11ª .ed, São Paulo, Companhia Editora Nacional, 1973.

ALVES, José Carlos Moreira, Direito Romano -- v.II, Rio de Janeiro, Forense, 1995.

ALVIM, Arruda, CÉSAR, Joaquim Pontes de Cerqueira e ROSAS, Roberto (org), Aspectos Controvertidos do novo Código Civil, São Paulo, RT, 2003.

ARENDT, HANNAH. As Origens do Totalitarismo, 2a . ed., Rio de Janeiro, Documentário, 1979.

A Condição Humana, 2a. ed., Rio de Janeiro,

Forense Universitária, 1983.

ARIÉS, Phillipe, L'enfant e la vie familiale sous l'Anciant Regime, Paris, Seuil, 1991.

ARIÉS, Phillipe e DUBY, Georges (org), A History of Private Life V Riddles of Identity in Modern Times, Londres, Harvard University Press, 1991.

História da Vida Privada $2-D a$

Europa Feudal à Renascença, São Paulo, Companhia das Letras, 1990.

ARISTÓTELES, Ética a Nicômaco, São Paulo, Edipro, 2002.

ASSOCIAÇÃO JUÍZES PARA A DEMOCRACIA, Direitos Humanos visões contemporâneas (obra coletiva), São Paulo, 2001.

AZEVEDO, Antônio Junqueira de, Negócio Jurídico - Existência, Validade e Eficácia, 4a . ed., São Paulo, Saraiva, 2002.

BARBERA, Lucio, L'idoneità affettiva tra interesse del minore e rapporti familiare: spunti sistematici”, in Quaderni di Diritto Civile (2004), Milano.

BERKOW, Robert (editor-chefe), Merck Research Laboratories, Manual Merck de Medicina, Diagnóstico e Tratamento, 16a . ed, São Paulo, Roca, 1995.

BEVILACQUA, Clóvis, Teoria Geral do Direito Civil. 3ª ed., Rio de Janeiro, Editora Rio, 1980

BITTAR, Carlos Alberto, Os Direitos da Personalidade, 7ª. ed., São Paulo, Saraiva, 2004.

BOBBIO, Norberto, A Era dos Direitos, Rio de Janeiro, Campus, 1992. Teoria do Ordenamento Jurídico, 10ª . ed., UNB, 1997.

BOSCARO, Marco Antonio, Direito de Filiação, São Paulo, RT, 2002. 
CARVALHO, Hilário Veiga de et alii, Compêndio de Medicina Legal, $2^{\mathrm{a}}$. ed., São Paulo, Saraiva, 1992.

CAVALIERI, Alyrio, 1000 Perguntas: Direito do Menor, Rio de Janeiro, Editora Rio, 1983

CAVARZERE, Thelma Thais, Direito Internacional da Pessoa Humana A Circulação Internacional de Pessoas, 2a . ed., Rio de Janeiro, Renovar, 2001.

CECIF - Centro de Capacitação e Incentivo à Formação de Profissionais, Voluntários e Organizações que Desenvolvam Trabalho de Apoio à Convivência Familiar, 101 Perguntas e Respostas sobre Adoção, São Paulo, 2001.

CESARINO JUNIOR, Antonio Ferreira, Seguro-Maternidade em Direito Comparado, São Paulo, RT, 1961

CHAPSAL, Madeleine, Ce qui m’a appris Françoise Dolto, Paris, Fayard, 1994.

CHAVES, Antonio, Adoção e Legitimação Adotiva, São Paulo, RT, 1966.

COMPARATO, Fábio Konder, A Afirmação Histórica dos Direitos Humanos, São Paulo, Saraiva, 1999.

CORREIA, Alexandre e SCIASCIA, Gaetano, Direito Romano 2, São Paulo, Saraiva, 1955.

CRÔNE, Richard, REVILLARD, Mariel e GELOT, Bertrand. L'Adoption, Aspectes Internes et Internationaux. Paris: Defrénois. 2006

CURY, Munir (org.). “Temas de direito do menor”, RT, 1987, São Paulo

CURY, Munir e outros. "Estatuto da Criança e do Adolescente Comentado - Comentários Jurídicos e Sociais”, 4ª edição, Malheiros, 2002

CURY, Munir, PAULA, Paulo Afonso Garrido de, e MARÇURA, Jurandir Norberto. "Estatuto da Criança e do Adolescente Comentado", 2a .edição, RT, São Paulo

DEL PRIORE, Mary (org). História das Crianças no Brasil. São Paulo: Contexto. 1999

Ao Sul do Corpo - Condição Feminina, Maternidades e Mentalidades no Brasil Colônia. Rio de Janeiro: José Olympio. 1993.

DE PLACIDO E SILVA, Vocabulário Jurídico, v.2, 11ª. ed., Rio de Janeiro, Forense, 1991.

DIAS, Maria Berenice, "Manual do Direito das Famílias", 4a. ed., São Paulo, RT, 2007 
DINIZ, Maria Helena, Código Civil Anotado, 10ª. ed., São Paulo, Saraiva, 2004

O Estado Atual do Biodireito, 4a. ed, São Paulo,

Saraiva, 2007

DOLTO, Françoise, Sexualidade Feminina, São Paulo, Martins Fontes, 1996. Destinos de Crianças - Adoção, Famílias, Trabalho

Social, São Paulo, Martins Fontes, 2006.

DINAMARCO, Cândido Rangel, Instituições de Direito Processual Civil v I, São Paulo, Malheiros, 2001.

ELIAS, Roberto João, Comentários ao Estatuto da Criança e do Adolescente, São Paulo, Saraiva, 1994.

FACHIN, Luiz Edson. Comentários ao Novo Código Civil - v. XVIII., Rio de Janeiro, Forense, 2003.

FÁVERO, Eunice Teresinha, Rompimento dos Vínculos do Pátrio Poder condicionantes socioeconômicos e familiares”, São Paulo, São Paulo, 2001.

FERREIRA, Márcia Regina Porto e CARVALHO, Sonia Regina, $1^{o}$. Guia de Adoção de Crianças e Adolescentes do Brasil, Winners Editorial, 2000, São Paulo.

FINE, Agnes e NEIRINCK, Claire (org.). Parents de Sang, Parents Adoptifs. Paris: L.G.D.J. 2000.

FREYRE, Gilberto. Sobrados e Mucambos. 14 $4^{\mathrm{a}}$. ed. São Paulo: Global Editora. 2003.

Casa-Grande \& Senzala. 19ª . ed. Rio de Janeiro: José Olympio. 1978.

GARCIA, Maria, Limites da Ciência, São Paulo, RT, 2004.

GIDDENS, Anthony, A Transformação da Intimidade, São Paulo, Editora UNESP, 1993.

GOGLIANO, Daisy, Direitos Privados da Personalidade, dissertação de Mestrado apresentada na Universidade de São Paulo, 1982.

GOMES, Orlando, Introdução ao Direito Civil, 10ª . ed., Forense, Rio de Janeiro, 1988.

GOVERNO DO ESTADO DE SÃO PAULO E OUTROS, Direito à convivência familiar e comunitária - novos enfoques e experiências inovadoras, Imprensa Oficial, São Paulo, 1999. 
GRANATO, Eunice Ferreira Rodrigues, Adoção - Doutrina \& Prática, Curitiba, Juruá Editora, 2003.

HOUAISS, Antônio e VILLAR, Mauro de Salles. Dicionário Houaiss da Língua Portuguesa, Rio de Janeiro, Objetiva, 2001.

ISHIDA, Válter Kenji, Estatuto da Criança e do Adolescente - Doutrina e Jurisprudência, 3ª edição, São Paulo, Atlas, 2001.

JORGE JUNIOR, Alberto Gosson, Comentários sobre a adoção no novo Código Civil, in Revista do Advogado 68/2002 ('Novo Código Civil - Aspectos Relevantes”), São Paulo, AASP, 2002

KUSANO, Suely Mitie, Adoção Intuitu Personae, tese de Doutorado apresentada na Pontifícia Universidade Católica, 2006 (domínio público)

LACERDA, Galeno, Direito de Família v. III, Rio de Janeiro, Forense, 2000

LEVITT, Steven e DUBNER, Stephen J., Freakonomics, London, Penguin Books, 2005

MACFARLANE, Alan. História do Casamento e do Amor - Inglaterra, 1300-1840, São Paulo, Companhia das Letras, 1990.

MAXIMILIANO, Carlos, Hermenêutica e Aplicação do Direito, 9a ${ }^{\mathrm{a}}$ ed, Rio de Janeiro, Forense, 1980.

MARCHI, Eduardo C. S, Guia de Metodologia Jurídica. Lecce, Grifo, 2004.

MARCÍlIO, Maria Luiza, História Social da Criança Abandonada, São Paulo, Hucitec, 1998.

MARMITT, Arnaldo, Adoção, Rio de Janeiro, Aide Editora, 1993.

DE MASI, Domenico e PEPE, Dunia (org.). "As palavras no tempo - vinte e seis vocábulos da Encyclopédie reescritos para o ano 2000”, Rio de Janeiro, José Olympio Editora, 2003.

MARANHÃO, Odon Ramos, Curso de Medicinal Legal, 5a.ed., São Paulo, Malheiros, 1992

MARQUES, José Frederico, Ensaio sobre a Jurisdição Voluntária, Campinas, Millenium, 2000

MONTEIRO, Washington de Barros, Curso de Direito Civil - Direito de Família. V. 2, 31ª . ed., São Paulo, Saraiva, 1994. 
MOTTA, Maria Antonieta Pisano, Mães Abandonadas: a entrega de um filho em adoção, São Paulo, Cortez, 2001.

NOJIRI, Sérgio, O Dever de Fundamentar as Decisões Judiciais, São Paulo, RT, 1999.

PEREIRA, Caio Mário da Silva, Instituições de Direito Civil - v.1, 2a . ed., Rio de Janeiro, Forense, 1990. Instituições de Direito Civil - v. III, $11^{\mathrm{a}}$. ed., Rio de Janeiro, Forense, 2003.

-Reconhecimento da Paternidade e seus Efeitos, $6^{\text {a }}$.ed., Rio de Janeiro, 2006.

PEREIRA, Lafayette Rodrigues, Direitos de Família, 4a . ed. atualizada por José Bonifácio de Andrada e Silva, Rio de Janeiro, Freitas Bastos, 1945.

PERELMAN, Chaïm. Lógica Jurídica. São Paulo, Martins Fontes, 2000.

Forense. Instituições de Direito Civil - v. III., $11^{\mathrm{a}}$. ed., Rio de Janeiro, Forense, 2003.

DE PLACIDO E SILVA, Vocabulário Jurídico, v.2, 11 ed., Rio de Janeiro: Forense, 1991.

PONTES DE MIRANDA, Francisco Cavalcanti. Tratado de Direito Privado-Parte Especial. .t. IX. 4ª . ed. São Paulo: RT. 1983

Tratado de Direito Privado - Parte Especial. .t.

9. Atualizado por Vilson Rodrigues Alves. Campinas: Bookseller. 2000.

Comentários à Constituição de 1967 - com a emenda $n .1$ de 1969. t. VI. Rio de Janeiro: Forense. 1987.

PORTO, Rosane de Albuquerque, A Roda dos Enjeitados e o Jogo no Discurso de Fazenda, dissertação de Mestrado apresentada à Universidade do Sul de Santa Catarina. (domínio público)

PROCURADORIA GERAL DO ESTADO DE SÃO PAULO - Centro de Estudos, Instrumentos Internacionais de Proteção dos Direitos Humanos, 1996, São Paulo RÁO, Vicente, "O Direito e a Vida dos Direitos", 2a . ed., São Paulo, Resenha Universitária, 1978

RODRIGUES, Sílvio, Direito Civil. V.6, 17ª . ed., São Paulo, Saraiva, 1991.

ROUDINESCO, Elizabeth, Jacques Lacan - Esboço de uma vida, história de um sistema de pensamento. São Paulo, Companhia das Letras, 1994. 
ROUMY, Franck, L'Adoption dans le Droit Savant du XIIe. Au XVe. Siècle, Paris, L.G.D.J,1998.

SCHETTINI FILHO, Luiz, Adoção - origem, segredo, revelação, Recife, Bagaço, 1999.

SILVA, José Afonso da, Curso de Direito Constitucional Positivo, 9a. ed, São Paulo, Malheiros, 1992.

SILVEIRA, Alípio, Hermenêutica no Direito Brasileiro, São Paulo, RT, 1968

STRENGER, Guilherme Gonçalves, Guarda de Filhos, São Paulo, LTr., 1998.

TEPEDINO, Gustavo, Temas de Direito Civil, 2a. ed., Rio de Janeiro, Renovar, 2001

VAINFAS, Ronaldo (dir.), Dicionário do Brasil Colonial (1500-1808), Rio de Janeiro, Objetiva, 2000.

VERONESE, Josiane Rose Petry, Temas de Direito da Criança e do Adolescente, São Paulo, LTr, 1997

VILELLA, João Baptista, Desbiologização da Paternidade, in Revista da Faculdade de Direito da UFMG v. 21/401-419, 1979

VOISINS, Virginie, L'Adoption em Droits Français et Anglais Compares, Aix-Marseille, PUAM, 2004. 


\section{RESUMO}

Desde a Antigüidade, a adoção apresenta um aspecto perturbador : é ao mesmo tempo contrato e instituição. Não fica claro a extensão da liberdade de escolha dos interessados. Na adoção intuitu personae, os pais adotivos são escolhidos pelos pais de sangue. O ordenamento jurídico brasileiro nem disciplina e nem proíbe. As práticas judiciárias são muito díspares.

O objetivo desta dissertação é o de determinar a natureza jurídica do consentimento para a adoção. Não é verdade que o poder familiar seja irrenunciável. O consentimento não passa de uma espécie de renúncia, animada da finalidade de melhorar a vida do filho.

O exercício do poder familiar é um direito da personalidade.Em conseqüência, a exclusão apriorística da possibilidade de escolha pela mãe biológica fere um direito da personalidade.

A única condição restritiva é a busca do melhor interesse da criança. 


\section{RESUMÉ}

Depuis l'Antiquité, l'adoption présente um aspect troublant: il s'agit à la fois d'um contract e d'une institution. Il n'est pas clair l'espace de choix des interessés. Dans l'adoption intuitu personae, les parents adoptifs sont choisis par les parents de sang. L'ordre juridique brésilienne ni l'établit ni l'interdit. Les pratiques judiciaires sont variables.

L'objectif de cette dissertation est celui de déterminer la nature juridique du consentiment pour l'adoption. Il n'est pas vrai que l'autorité parentale soit irrenonçable. Le consentiment n'est qu'une espèce de renonce, animée par la finalité d'ammeliorer la vie de l'enfant.

L'exercice de l'autorité parentale est un droit de la personnalité. Par conséquent, l'exclusion a priori du choix de la mère biologique méconnait um droit de la personnalité.

La seule condition restrictive est la récherche du meilleur intêret de l'enfant. 